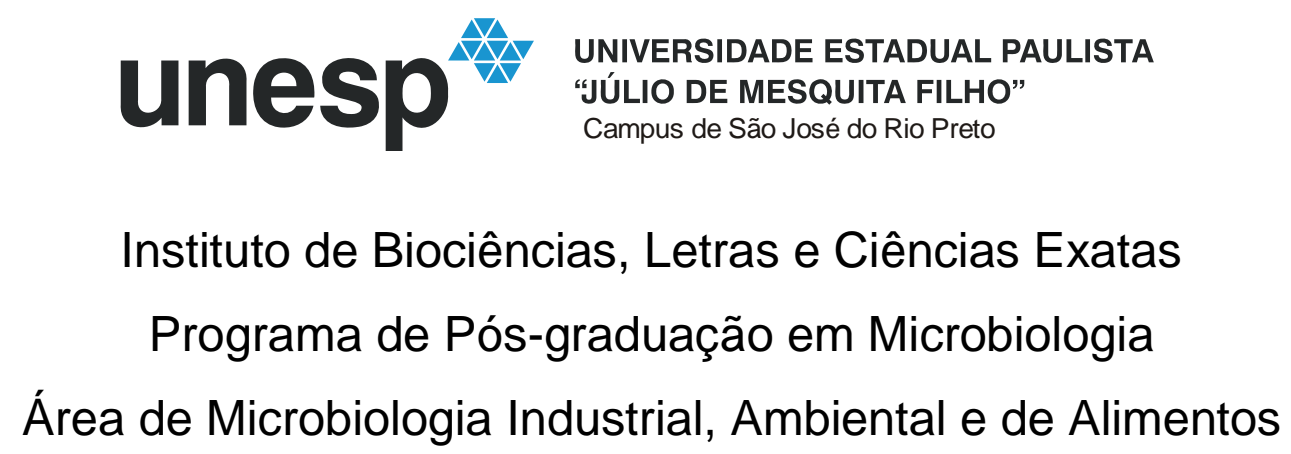

Aline Teodoro de Paula

\title{
ATIVIDADE ANTIMICROBIANA DE MICRORGANISMOS PROBIÓTICOS EM BEBIDAS LÁCTEAS FERMENTADAS
}

São José do Rio Preto

2010 


\section{ALINE TEODORO DE PAULA}

\section{ATIVIDADE ANTIMICROBIANA DE MICRORGANISMOS PROBIÓTICOS EM BEBIDAS LÁCTEAS FERMENTADAS}

Dissertação apresentada para obtenção do título de Mestre em Microbiologia, área de Microbiologia Ambiental, Industrial e de Alimentos junto ao Programa de Pós-Graduação em Microbiologia do Instituto de Biociências, Letras e Ciências Exatas da Universidade Estadual Paulista "Júlio de Mesquita Filho", Campus de São José do Rio Preto.

Orientadora: $\operatorname{Prof}^{\mathrm{a}}{ }^{\mathrm{Dr}}{ }^{\mathrm{a}}$ Ana Lúcia Barretto Penna 
Paula, Aline Teodoro de

Atividade antimicrobiana de microrganismos probióticos em bebidas lácteas fermentadas/ Aline Teodoro de Paula. - São José do Rio Preto : [s.n.], 2010.

$85 \mathrm{f.}: 30 \mathrm{~cm}$

Orientador: Ana Lúcia Barretto Penna

Dissertação (mestrado) - Universidade Estadual Paulista, Instituto de Biociências, Letras e Ciências Exatas

1. Microbiologia de alimentos. 2. Atividade antimicrobiana. 3. Probióticos. 4. Bebida láctea fermentada. I. Penna, Ana Lúcia Barretto. II. Universidade Estadual Paulista, Instituto de Biociências, Letras e Ciências Exatas. III. Título.

$$
\text { CDU - } 579.67
$$

Ficha catalográfica elaborada pela Biblioteca do IBILCE Campus de São José do Rio Preto - UNESP 


\section{ALINE TEODORO DE PAULA}

\section{ATIVIDADE ANTIMICROBIANA DE MICRORGANISMOS PROBIÓTICOS EM BEBIDAS LÁCTEAS FERMENTADAS}

Dissertação apresentada para obtenção do título de Mestre em Microbiologia, área de Microbiologia Ambiental, Industrial e de Alimentos junto ao Programa de Pós-Graduação em Microbiologia do Instituto de Biociências, Letras e Ciências Exatas da Universidade Estadual Paulista "Júlio de Mesquita Filho", Campus de São José do Rio Preto.

\section{BANCA EXAMINADORA}

Prof ${ }^{a}$. Dra ${ }^{\text {a }}$. Ana Lúcia Barretto Penna

Professor Adjunto

UNESP - São José do Rio Preto

Orientador

Prof ${ }^{a}$. Dr ${ }^{\mathrm{a}}$. Elaine Cristina Pereira De Martinis

Professor Adjunto

Universidade de São Paulo

Prof. Drª . Eleni Gomes

Professor Adjunto

UNESP - São José do Rio Preto

São José do Rio Preto, 19 de fevereiro de 2010. 
"Não é com o tamanho do seu sonho que você deve preocupar. Mas sim, com a força e as pessoas que necessitará para realizá-lo" Dan Loth 


\section{AGRADECIMENTOS}

À Professora Dra. Ana Lúcia, por me acolher como orientadora, pela confiança, ajuda, paciência e aos ensinamentos para consolidação deste trabalho.

Ao carinho e ao companheirismo das meninas do Laboratório de Leite e Derivados: Íris, Grazi, Luana, Tati, Raquel e Michele.

À Jana, minha companheira de trabalho, de vida, de amizade, de tolerância e aprendizado.

À Sabrina, sem ela esse sonho jamais teria se consolidado. Obrigado pelo incentivo, pela força, ajuda e carinho, pelos ensinamentos e amizade.

Ás amigas que ganhei no meu novo lar: Tâmara, Vivi e Simara.

Ao técnico Ginaldo, pelo auxílio prestado.

Á Christian Hansen, pelas culturas doadas.

Aos meus pais, Almir e Ligia e ao meu irmão, Anderson, pelo incentivo, pela ajuda, pelos ensinamentos e pelo amor incondicional.

Ao meu namorado, Fernando, por estar sempre ao meu lado acreditando e incentivando meus sonhos, pela paciência, amor e companheirismo.

A Deus, por me auxiliar que este sonho se tornasse um objetivo concreto. 


\section{SUMÁRIO}

\section{RESUMO}

\section{ABSTRACT}

\section{LISTA DE FIGURAS}

\section{LISTA DE QUADROS E TABELAS}

\section{LISTA DE ABREVIAÇÕES}

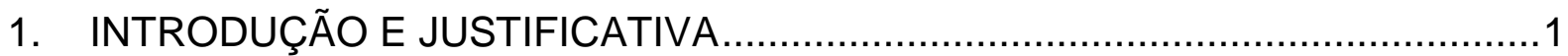

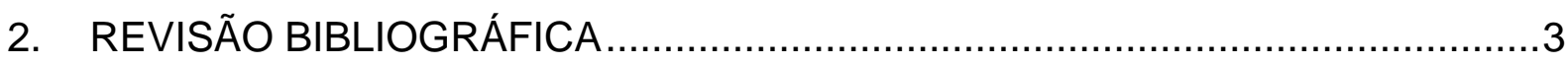

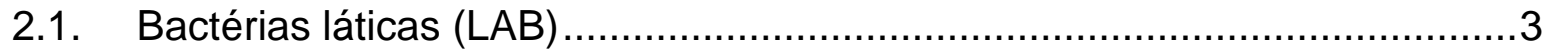

2.1.1. Substâncias antimicrobianas produzidas por bactérias láticas ................ 4

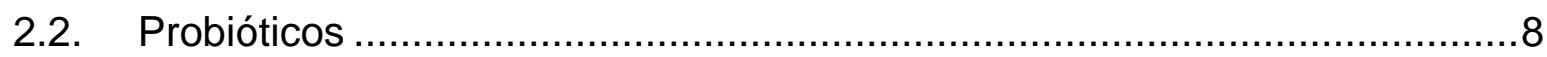

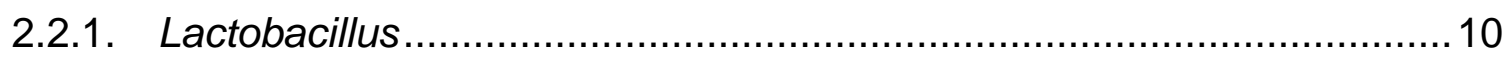

2.2.1.1. Lactobacillus acidophilus .....................................................10

2.2.1.2. Lactobacillus casei...........................................................12

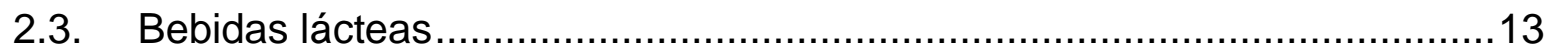

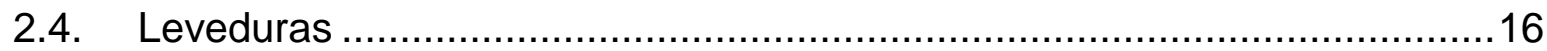

2.4.1. Cryptococcus albidus e Cryptococcus laurentii...................................20

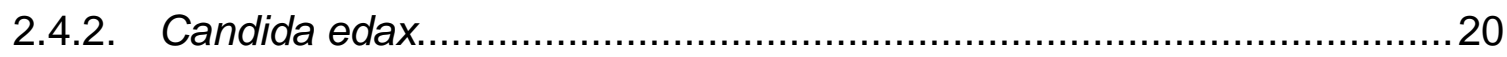

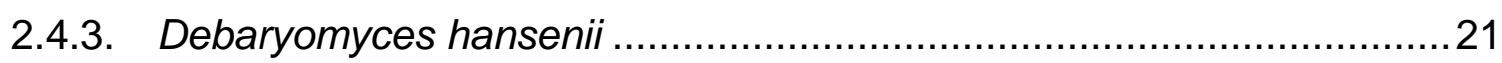

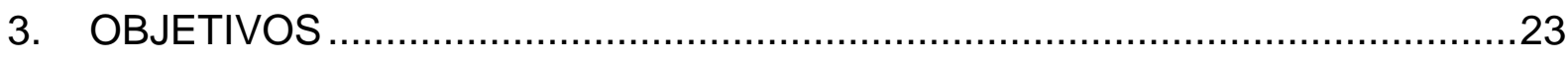

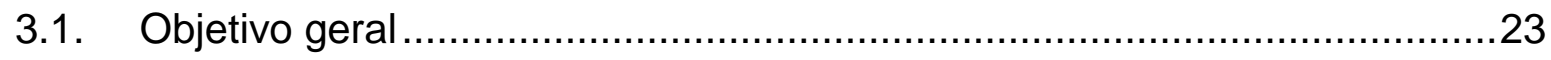

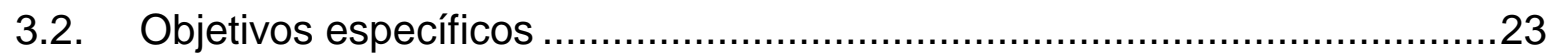

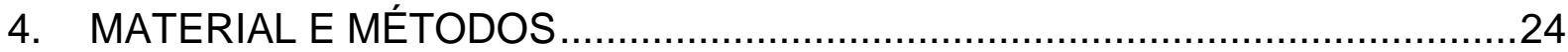

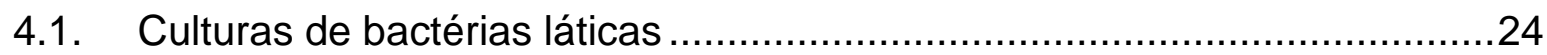

4.1.1. Viabilidade das culturas de bactérias láticas ......................................24

4.1.2. Obtenção do sobrenadante livre de células probióticas ........................25

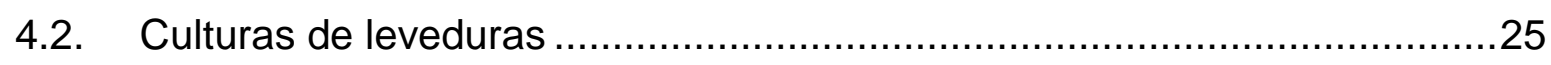

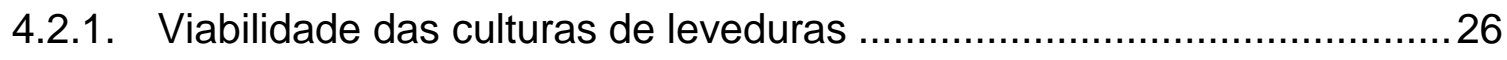

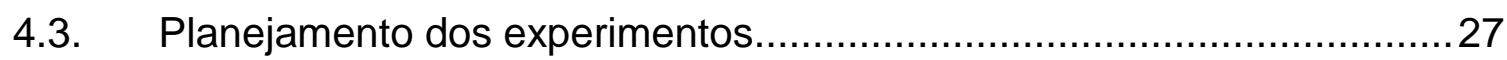




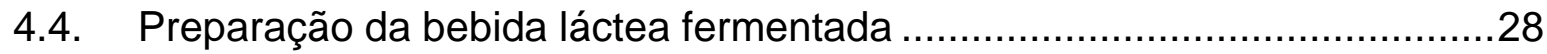

4.5. Avaliação da bebida láctea fermentada ............................................... 30

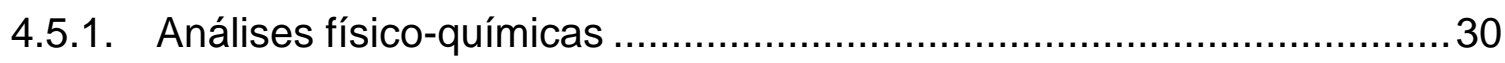

4.5.2. Viabilidade das bactérias láticas e das leveduras no produto ................31

4.6. Avaliação da bebida láctea fermentada durante a vida de prateleira ...........31

4.7. Análise estatística dos resultados experimentais......................................32

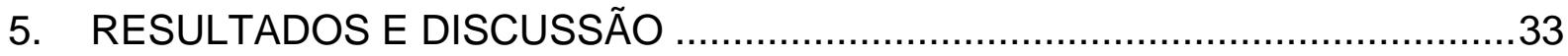

5.1. Capacidade antimicrobiana de Lactobacillus acidophilus e Lactobacillus casei .33

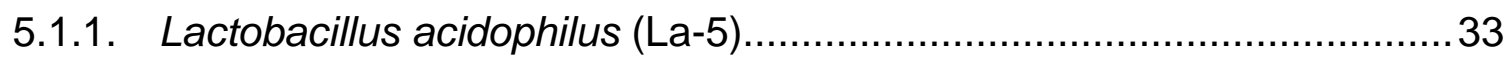

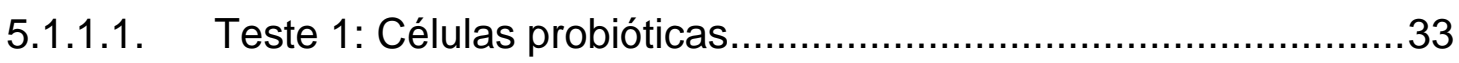

5.1.1.2. Teste 2: Sobrenadante livre de células e seu concentrado ...........34

5.1.1.3. Teste 3: Sobrenadante livre de células e seu concentrado neutralizados 37

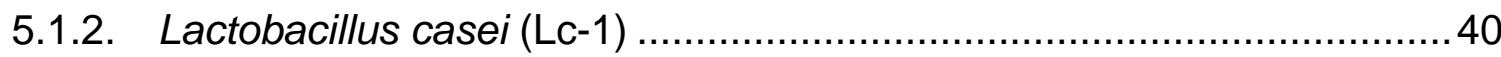

5.1.2.1. Teste 1: Células probióticas...................................................... 40

5.1.2.2. Teste 2: Sobrenadante livre de células e seu concentrado ..........41

5.1.2.3. Teste 3: Sobrenadante livre de células e seu concentrado

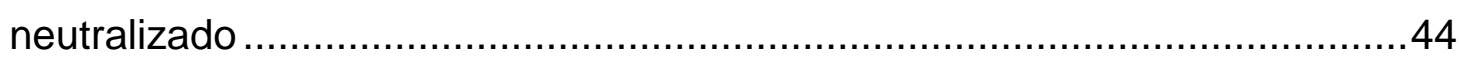

5.1.3. Protocooperação de Debaryomyces hansenii e culturas probióticas..... 47

5.2. Bebida láctea fermentada pelas culturas probióticas ..................................49

5.2.1. Caracterização físico-química ........................................................... 49

5.2.1.1. Teores de sólidos totais ........................................................ 49

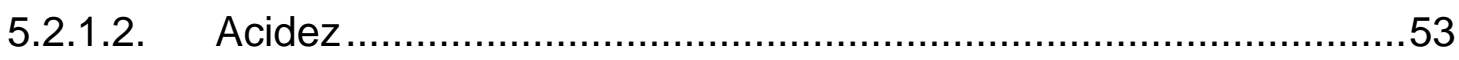

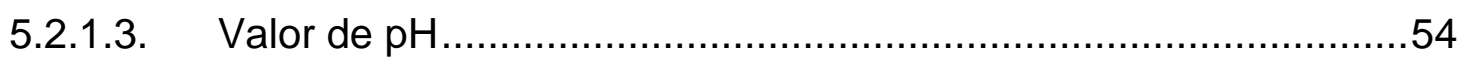

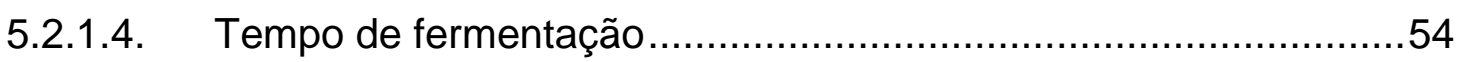

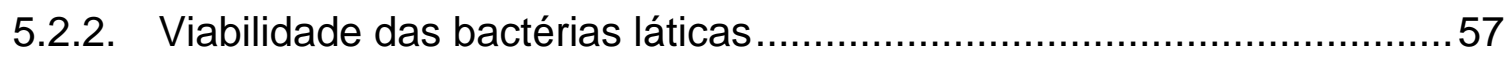

5.2.3. Viabilidade de fungos filamentosos e leveduriformes ..........................60

5.2.4. Atividade antimicrobiana da bebida láctea fermentada por bactérias

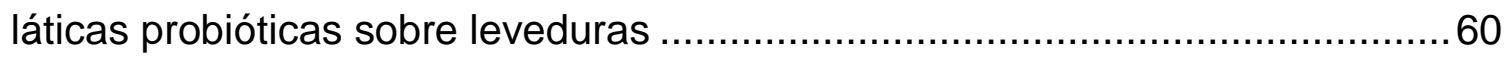

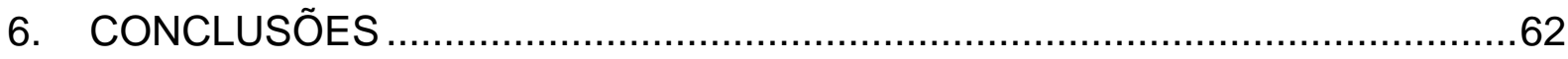

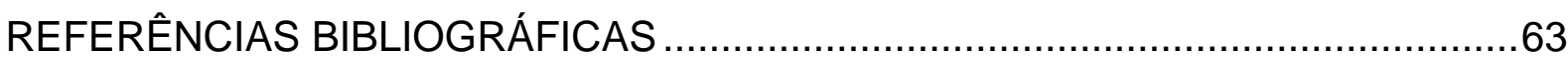




\section{RESUMO}

A produção de alimentos minimamente processados e a redução do uso de aditivos químicos tem sido uma tendência das indústrias para atender o mercado consumidor, que busca alimentos mais saudáveis. Todavia, os produtos lácteos são excelentes meios para o crescimento de microrganismos patogênicos e/ou deteriorantes. Estudos relatam que as bactérias láticas (LAB) probióticas adicionadas em produtos lácteos fermentados produzem componentes orgânicos antimicrobianos, que podem atuar como inibidores de crescimento desses microrganismos. $\mathrm{O}$ objetivo deste trabalho foi avaliar o efeito antimicrobiano in vitro de bactérias láticas comerciais (Lactobacillus casei Lc-1 e Lactobacillus acidophilus La-5) sobre leveduras (Debaryomyces hansenii var. fabryii, Candida edax, Cryptococcus albidus e Cryptococcus laurentii) e em bebidas lácteas. A atividade antimicrobiana in vitro das culturas La-5 e Lc-1 foram avaliadas em três testes: 1) células probióticas, 2) sobrenadante livre de células e seu concentrado, 3) sobrenadante neutralizado e seu concentrado neutralizado. No teste in situ foram produzidas bebidas lácteas fermentadas por La-5 e Lc-1 inoculadas com C. albidus e LC-1 somente inoculada com $C$. laurentii. Nas bebidas lácteas foram realizadas análises físico-químicas, para determinar os teores de sólidos totais, $\mathrm{pH}$, acidez titulável, e microbiológicas para verificar a viabilidade das bactérias láticas, durante 60 dias de estocagem refrigerada. Os ensaios com células em diferentes concentrações não apresentaram atividade antimicrobiana. O sobrenadante livre de células, sobrenadante concentrado, sobrenadante neutralizado e sobrenadante concentrado neutralizado de La-5 e Lc-1 apresentaram atividade antimicrobiana sobre C. albidus, e Lc-1 também para $C$. laurentii. A presença da levedura influenciou o valor de $\mathrm{pH}$ e a acidez durante a estocagem refrigerada, além de interferir no tempo de fermentação. Houve inibição do crescimento da levedura nas bebidas lácteas fermentadas. $O$ efeito antimicrobiano das bactérias láticas probióticas La-5 e Lc-1, observado in vitro e in situ, apresentam mecanismos diferentes. As culturas probióticas comerciais La-5 e Lc-1 podem ser utilizadas como bioconservantes de produtos lácteos, oferecendo produtos seguros com ampla vida de prateleira.

Palavras-chave: atividade antimicrobiana, probióticos, bebida láctea. 


\begin{abstract}
The production of minimally processed foods and the reduction of the use of chemical additives has been a tendency of industries to meet the demand of the consumer market that seek healthier foods. However, dairy products are an excellent media to the growth of pathogenic and/or deteriorating microorganisms. Studies report that lactic acid bacteria ( $L A B$ ) probiotic added in fermented dairy products produce antimicrobials organics components, which can act as inhibitors of the growth of these microorganisms. The aim of this study was to evaluate the antimicrobial effect in vitro of commercial lactic acid bacteria (Lactobacillus casei Lc-1 and Lactobacillus acidophilus La-5) against yeasts (Debaryomyces hansenii var. fabryii, Candida edax, Cryptococcus albidus and Cryptococcus laurentii), and in whey beverage. The in vitro antimicrobial activity of cultures La-5 and Lc-1 were evaluated in three tests: 1) probiotic cells, 2) cell-free supernatant, concentrated supernatant, 3) neutralized supernatant and neutralized concentrated supernatant. The in situ study produced whey beverages fermented by La-5 and Lc-1 and inoculated with $C$. albidus and only Lc-1 inoculated with C. laurentii. In whey beverages samples, physicochemical analysis to determine the total solids, $\mathrm{pH}$, acidity and microbiological characteristics to verify the viability of lactic acid bacteria during 60 days of refrigerated storage were carried out. The tests with cells in different concentrations did not show antimicrobial activity. The cell-free supernatant, concentrated supernatant, neutralized supernatant and neutralized concentrated supernatant of La-5 and Lc-1 showed activity against $C$. albidus and LC-1 against $C$. laurentii either. The presence of the yeast influenced the $\mathrm{pH}$ and acidity during refrigerated storage, and affected the fermentation time. There was inhibition of growth of yeast in fermented whey beverages. The antimicrobial effect of lactic acid bacteria probiotic La-5 e Lc-1 was observerd in vitro and in situ, have differents mechanisms. The commercial probiotics La-5 and Lc-1 may be used as biopreservatives products, offering safe products with a wider shelf life.
\end{abstract}

Keywords: antimicrobial activity, probiotic, whey beverages. 


\section{LISTA DE FIGURAS}

páginas

Figura 1 Fluxograma do processo de fabricação de bebidas 14 lácteas fermentadas

Figura 2 Esquema de compostos metabólicos produzidos e 17 assimilados por bactérias láticas e leveduras.

Figura 3 Planejamento dos experimentos a partir do estudo do 27 comportamento antimicrobiano in vitro, em duplicata.

Figura 4 Fluxograma do processo de fabricação de bebidas 30 lácteas fermentadas.

Figura 5 Atividade antimicrobiana das células de La-5 sobre 34 Debaryomyces hansenii, nas concentrações $10^{6}$ UFC. $\mathrm{mL}^{-1}$ (1), $10^{8}$ UFC. $\mathrm{mL}^{-1}$ (2), $10^{10}$ UFC. $\mathrm{mL}^{-1}$ (3), $10^{12}$ UFC. $\mathrm{mL}^{-1}(4)$.

Figura 6 Efeito antimicrobiano do sobrenadante livre de células
(1) e sobrenadante concentrado
(2) de La-5 sobre Cryptococcus albidus.

Figura 7 Efeito antimicrobiano do sobrenadante livre de células 40

(1) e sobrenadante concentrado neutralizados (2) de La5 sobre a Cryptococcus albidus.

Figura 8 Atividade antimicrobiana das células de Lc-1 sobre 41 Debaryomyces hansenii, nas concentrações $10^{6}$ UFC. $\mathrm{mL}^{-1}(1), 10^{8}$ UFC. $\mathrm{mL}^{-1}(2), 10^{10}$ UFC. $\mathrm{mL}^{-1}$ (3), $10^{12}$ UFC. $\mathrm{mL}^{-1}(4)$.

Figura 9 Efeito antimicrobiano do sobrenadante livre de células 43
(1) e sobrenadante concentrado
(2) de LC-1 sobre Cryptococcus albidus.

Figura 10 Efeito antimicrobiano do sobrenadante livre de células
(1) e sobrenadante concentrado
(2) de LC-1 sobre Cryptococcus laurentii.

Figura 11 Efeito antimicrobiano do sobrenadante livre de células 46 (1) e sobrenadante concentrado neutralizados (2) de Lc1 sobre Cryptococcus albidus. 
Figura 12 Halos com intenso desenvolvimento demonstrando a 49 interação positiva de Debaryomyces hansenii com os compostos orgânicos produzidos por La-5 (1) e Lc-1(2).

Figura 13 Curvas de acidificação das bebidas lácteas fermentadas 56 pela cultura La-5.

Figura 14 Curvas de acidificação das bebidas lácteas fermentadas 56 pela cultura LC-1. 


\section{LISTA DE TABELAS}

páginas

Tabela 1 Distribuição das espécies de leveduras utilizadas e 26 identificação da amostra de origem.

Tabela 2 Testes realizados para avaliar a atividade 28 antimicrobiana.

Tabela 3 Atividade antimicrobiana do sobrenadante livre de 36 células e seu concentrado de Lactobacillus acidophilus La-5, obtido pelo método de perfuração e difusão em ágar. Valores dos halos de inibição em $\mathrm{mm}$.

Tabela 4 Atividade antimicrobiana do sobrenadante livre de célula 38 e seu concentrado neutralizados de Lactobacillus acidophilus La-5, obtido pelo método de perfuração e difusão em ágar. Valores dos halos de inibição em mm.

Tabela 5 Atividade antimicrobiana do sobrenadante livre de 42 células e seu concentrado de Lactobacillus casei Lc-1, obtido pelo método de perfuração e difusão em ágar. Valores dos halos de inibição em $\mathrm{mm}$.

Tabela 6 Atividade antimicrobiana do sobrenadante livre de célula 46 e seu concentrado neutralizados de Lactobacillus casei Lc-1, obtido pelo método de perfuração e difusão em ágar. Valores dos halos de inibição em $\mathrm{mm}$.

Tabela 7 Características físico-químicas das bebidas lácteas fermentadas pela cultura La-5.

Tabela 8 Características físico-químicas das bebidas lácteas fermentadas pela cultura Lc-1.

Tabela 9 Densidade populacional de L. acidophilus (log UFC. $\mathrm{mL}^{-1}$ ) 58 das bebidas lácteas fermentadas pela cultura La-5 durante a estocagem refrigerada.

Tabela 10 Densidade populacional de L. casei (log UFC. $\mathrm{mL}^{-1}$ ) das 58 bebidas lácteas fermentadas pela cultura Lc-1 durante a estocagem refrigerada. 


\section{LISTA DE ABREVIAÇÕES}

$\begin{array}{ll}\text { APPCC } & \text { Análise de Perigos e Pontos Críticos de Controle } \\ \text { BPF } & \text { Boas práticas de fabricação } \\ \text { La-5 } & \text { Cultura de Lactobacillus acidophilus } \\ \text { LC-1 } & \text { Cultura de Lactobacillus casei } \\ \text { MRS } & \text { De Man Rogosa Sharp } \\ \text { D } & \text { Dextrógiro }\end{array}$

FAO Food and Agriculture Organization of United Nations

G

Força da gravidade

$\mathrm{CO}_{2} \quad$ Gás carbônico

G

Gramas

$\stackrel{\circ}{-C}$

Graus Celsius

${ }^{\circ}$ Graus Dornic

h Horas

IDF International Dairy Federation

kg Kilogramas

LAB Lactic acid bacteria

L Levógiro

log Logarítmo

MPL Meio para levedura

$\mu \mathrm{L} \quad$ Micrôlitro

um Micrômetro

mg Miligramas

$\mathrm{mL} \quad$ Mililitro

mm Milímetro

m Minutos

NSLAB Non starter lactic acid bacteria

$\mathrm{H}_{2} \mathrm{O}_{2} \quad$ Peróxido de hidrogênio

$\mathrm{NaOH} \quad$ Peróxido de sódio

pH Potencial hidrogeniônico

kDa QuiloDalton

SLC Sobrenadante livre de células

SLCC Sobrenadante livre de células concentrado 
SLCCN Sobrenadante livre de células concentrado neutralizado

SLCN Sobrenadante livre de células neutralizado

UFC Unidades Formadoras de Colônias

YM Yeast and Moulds 


\section{INTRODUÇÃO E JUSTIFICATIVA}

Nos últimos anos, têm aumentado o interesse dos consumidores por produtos saudáveis, menos processados, sem conservantes, com ampla vida de prateleira e propriedades terapêuticas. A demanda tem chamado à atenção das indústrias, fazendo com que estas busquem novas tecnologias para garantir ou ampliar o mercado.

Os alimentos funcionais são fontes ricas em nutrientes que proporcionam ao consumidor benefícios à saúde, resultando em elevada demanda no mercado. As bebidas lácteas probióticas estão incluídas entre os alimentos funcionais, e são alimentos ou suplementos alimentícios que contêm células vivas de microrganismos com propriedades terapêuticas, equilibrando a microbiota intestinal e regulando as funções fisiológicas do intestino. Grande parte dos microrganismos probióticos envolvidos na produção de produtos lácteos pertence aos gêneros Streptococcus, Lactococcus, Leuconostoc, Bifidobacterium e Lactobacillus.

Por outro lado, pelo elevado valor nutritivo, os produtos lácteos são excelentes meios para o crescimento de microrganismos patogênicos e deteriorantes. Em produtos lácteos fermentados, a presença de fungos filamentosos e leveduriformes como microrganismos deteriorantes foi relatada por diversos pesquisadores e demonstra ser originária de falhas higiênico-sanitárias que podem ocorrer desde a matéria-prima, processamento e obtenção do produto final. Estes microrganismos promovem fermentação com formação de gás, resultando em sabores desagradáveis, deteriorando o produto, e conseqüentemente comprometendo a sua vida de prateleira. $\mathrm{O}$ baixo valor de $\mathrm{pH}$ e a elevada concentração de ácido lático são meios propícios para o desenvolvimento de alguns microrganismos deteriorantes, e quando presentes tornam o produto impróprio para o consumo, e ainda, caso seja consumido, pode afetar a saúde dos consumidores.

Para garantir a segurança de um produto para os consumidores, as indústrias têm utilizado ferramentas de gestão da qualidade, como as Boas Práticas de Fabricação (BPF) e Análise de Perigos e Pontos Críticos de Controle (APPCC).

Apesar da introdução destes programas de qualidade na produção de alimentos, elevado número de doenças veiculadas por alimentos e intoxicações ainda ocorrem. Assim, diversos estudos têm se dedicado a aplicações de culturas 
protetoras, como as de bactérias láticas, para aumentar as condições higiênicosanitárias de produtos lácteos. Evidentemente, a conservação biológica não substitui as boas práticas de fabricação, mas oferece uma ferramenta adicional para melhorar a qualidade do alimento.

As bactérias láticas ( $L A B)$ probióticas adicionadas em produtos lácteos fermentados produzem componentes orgânicos antimicrobianos, que podem atuar como inibidores de crescimento de microrganismos deteriorantes e/ou patogênicos. Dentre esses componentes produzidos, destacam-se: ácidos orgânicos (ácido lático), peróxido de hidrogênio, dióxido de carbono, diacetil, acetaldeído e bacteriocinas. Uma vez presentes no produto, esses podem atuar como conservantes naturais, aumentando a vida útil do produto.

Diversos gêneros de LAB isoladas de leites, carnes e seus derivados apresentam efeito antimicrobiano sobre patógenos, tais como Listeria spp., Clostridium spp., Staphylococcus aureus, Bacillus spp., Salmonella spp., Helicobacter pylori, bactérias do grupo coliforme e alguns fungos. Lactobacilllus casei e Lactobacillus acidophilus produzem ácido lático, o peróxido de hidrogênio e bacteriocinas, que inibem o crescimento de fungos e leveduras deteriorantes, como Candida sp.

Entretanto, estudos mais detalhados a respeito da ação antimicrobiana destas LAB sobre leveduras deteriorantes em produtos lácteos são escassos.

Neste contexto, estudos para verificar a capacidade antimicrobiana de diferentes culturas probióticas em bebidas lácteas fermentadas sobre leveduras isoladas de produtos lácteos poderão contribuir nas inovações tecnológicas das indústrias lácteas nacionais, desenvolvendo alimentos seguros, saudáveis, além de contribuir para o aumento da vida de prateleira do produto. 


\section{REVISÃO BIBLIOGRÁFICA}

\subsection{Bactérias láticas (LAB)}

Bactérias láticas constituem um grupo de microrganismos amplamente distribuídos nos alimentos, tendo grande importância industrial para a produção de lácteos fermentados, produtos de carne e vegetais (BROMBERG et al., 2006). Durante anos, o homem tem explorado o uso de bactérias láticas. A utilização desses microrganismos ( $L A B$ ) vem sendo aplicada em produtos fermentados que transformam açúcares fermentáveis em ácido lático, etanol e outros metabólitos. Além disso, contribuem para tornar esses alimentos mais seguros, modificam as características sensoriais, tecnológicas e nutricionais, proporcionando melhorias na qualidade final do produto, além de agregar vantagens para saúde de seus consumidores (DE VUYST; LEROY, 2007).

Esses microrganismos englobam vários gêneros e um número considerável de espécies. Os principais gêneros utilizados em produtos lácteos são Lactococcus, Leuconostoc, Streptococcus, Lactobacillus e bifidobactérias. Embora sejam geneticamente diferentes, notam-se características comuns: são Gram positivos, catalase negativos, desprovidos de citocromos, imóveis e não formam esporos. Sua aparência morfológica é a de cocos ou bacilos. De acordo com a temperatura ótima de crescimento, são classificados como mesofílicos (20-30º) e termofílicos (35$45^{\circ} \mathrm{C}$ ). Em anaerobiose têm crescimento ótimo, mas também são aerotolerantes. São homofermentativos, os quais utilizam a via Embden-Meyerhof transformando a fonte de carbono em ácido lático quase que exclusivamente, ou heterofermentativos, os quais utilizam a via fosfocetolase, produzindo ácido lático e outros compostos, como $\mathrm{CO}_{2}$ e etanol. As bactérias láticas necessitam de nutrientes específicos, como aminoácidos e vitaminas, sendo classificadas como microrganismos fastidiosos. Além disso, são ácido tolerantes, com metabolismo estritamente fermentativo (WALSTRA; WOUTERS; GEURTS, 2006).

As bactérias láticas possuem enzimas glicolíticas, proteolíticas e lipolíticas, que transformam os nutrientes presentes no leite (VILJOEN, 2001). Estas promovem a fermentação e como conseqüência acumulam ácidos orgânicos e acidificando o meio, alterando as características finais do produto, tais como aroma, textura e 
sabor. Além disso, possuem a capacidade de inibir o desenvolvimento de microrganismos patogênicos e/ou deteriorantes por meio da produção de outros metabólitos orgânicos (HUI, 1993; JAMUNA; JEEVARATNAM, 2004).

\subsubsection{Substâncias antimicrobianas produzidas por bactérias láticas}

Diversas espécies de bactérias láticas são produtoras de substâncias antimicrobianas. Desses constituintes inibidores, os mais comumente conhecidos são o ácido lático e o acético, correspondendo a mais de $90 \%$ da produção de ácidos orgânicos, resultando no decréscimo de pH. Dependendo das condições de crescimento, podem produzir também outras moléculas bioativas, como ácidos graxos, peróxido de hidrogênio, dióxido de carbono, etanol, ácido fórmico, diacetil, acetaldeído, D-leucina, enzimas bacteriolíticas, bacteriocinas, antifúngicos e antibióticos (HUI, 1993; AKTYPIS; KALANTZOPOULOS, 1996; MORENO; VIALTA, 1999; SHAH, 2007; DE VUYST; LEROY, 2007).

Outros sistemas antagônicos mais complexos, como competição por nutrientes, redução do potencial de óxido-redução e coagregação de células, também podem favorecer a inibição de microrganismos indesejáveis (MORENO; VIALTA, 1999).

Nos últimos anos, estes componentes antimicrobianos produzidos pelas $L A B$, os bioconservantes, têm sido aplicados em produtos lácteos pelas indústrias alimentícias (HUI, 1993, SHAH, 2007, DE VUYST; LEROY, 2007).

Uns dos agentes antimicrobianos comumente utilizados na conservação de alimentos são os ácidos orgânicos lático, acético, benzóico e sórbico, que podem ser produzidos por microrganismos. Uma vez presentes no meio, podem inibir o crescimento de bactérias e fungos. Devido ao baixo $\mathrm{pH}$, as células alvo sofrem modificações na permeabilidade e no potencial elétrico da membrana, inibindo o transporte ativo, permitindo que esses componentes orgânicos se difundam, reduzindo $\mathrm{opH}$ intracelular e inibindo uma variedade de funções metabólicas. No interior da célula, as moléculas se dissociam liberando ânions, alterando o equilíbrio osmótico. Estas alterações intracelulares podem ocasionar prejuízos para a célula, por meio do rompimento da membrana celular, toxicidade por acúmulo de ânions e estresse osmótico e inibição das reações metabólicas principais (BRUL; COOTE, 1999). Um exemplo é a bactéria ácido propiônica (Propionibacterium freudenreichii), 
a qual produz ácido propiônico que atua como bioconservante nos produtos, desencadeando atividade antimicrobiana sobre a microrganismos, incluindo fungos filamentosos e leveduriformes (ROSS; MORGAN; HILL, 2002).

Outro fator que possui a capacidade de inibir microrganismos patogênicos e/ou deteriorantes é o sistema de lactoperoxidase encontrado no leite. Sobre condições experimentais favoráveis, radicais altamente reativos são formados a partir do peróxido de hidrogênio, atuando como potentes agentes antimicrobianos sobre bactérias Gram negativas e Gram positivas. Além disso, possuem um forte efeito oxidativo na membrana lipoprotéica e nas proteínas celulares. Como alternativa, o peróxido de hidrogênio $\left(\mathrm{H}_{2} \mathrm{O}_{2}\right)$ pode ser adicionado em alimentos na forma de aditivo. As concentrações de peróxido de hidrogênio, a temperatura e o pH são extremamente importantes na atividade da lactoperoxidase (BRUL; COOTE, 1999, ROSS; MORGAN; HILL, 2002).

Nos Estados Unidos, a adição de $\mathrm{H}_{2} \mathrm{O}_{2}$ em produtos lácteos é permitida na preparação de certos queijos (BRUL; COOTE, 1999). No entanto, no Brasil o Regulamento Técnico de Identidade e Qualidade de Queijos (BRASIL, 1996) e a Instrução Normativa 51, que aprova os Regulamentos Técnicos de Produção, Identidade e Qualidade do Leite tipo A, do Leite tipo B, do Leite tipo C, do Leite Pasteurizado e do Leite Cru Refrigerado e o Regulamento Técnico da Coleta de Leite Cru Refrigerado e seu Transporte a Granel (BRASIL, 2002), não incluem o peróxido de hidrogênio entre os aditivos autorizados para uso em queijos ou em leite.

Descobertas há cerca de sete décadas, as bacteriocinas têm sido amplamente estudadas como potenciais ferramentas biológicas para melhorar a segurança alimentar (MORENO et al., 1999). Estas bacteriocinas são proteínas ou peptídeos, que atuam sobre bactérias como inibidores de crescimento em espécies estreitamente relacionadas, ou mesmo em linhagens diferentes da mesma espécie (LJUNGH; TORKEL, 2006; BROMBERG et al., 2006). No entanto, essa propriedade bacteriocinogênica é encontrada somente em algumas espécies de bactérias láticas.

De acordo com seu espectro de atividade, as bacteriocinas são divididas em dois tipos: o primeiro tipo exibe um espectro de atividade apenas contra as espécies homólogas e um segundo tipo, menos comum, que apresenta um amplo espectro de ação contra uma variedade de microrganismos Gram positivos (MORENO; LERAYER; LEITÃO, 2008). Além disso, as bacteriocinas são divididas em três 
classes, de acordo com a estrutura química, peso molecular e estabilidade térmica, em: (I) lantibióticos: pequenos peptídeos contendo de 19-38 aminoácidos, com baixo peso molecular $<5 \mathrm{kDa}$, estáveis ao aquecimento e que contêm lantionina e derivados, (II) pequenos peptídeos contendo de 19-38 aminoácidos, com baixo peso molecular < $10 \mathrm{kDa}$, estáveis ao aquecimento, não contêm lantionina, e (III) grandes peptídeos de alto peso molecular $>30 \mathrm{kDa}$, sensíveis ao aquecimento, contendo autolisinas. No entanto, essa classificação tem mudado constantemente (DE VUYST; LEROY; 2007).

As bacteriocinas são produzidas por bactérias láticas Gram positivas e Gram negativas, destacando-se os gêneros: Lactobacillus, Lactococcus, Leuconostoc, Carnobacterium, Streptococcus, Enterococcus, além das bifidobactérias (HUI, 1993; MORENO et al., 2000a). Acredita-se que a maioria das bacteriocinas de bactérias láticas tenha um mecanismo de ação comum, estas substâncias são geralmente catiônicas, anfipáticas e dissipam a força próton motiva, provocando um desequilibro no potencial da membrana e no gradiente de concentração de prótons, desencadeando a formação de poros na membrana e a inibição de síntese da parede celular (BRUL; COOTE, 1999; SCHULZ et al., 2003). Além disso, esses bioconservantes possuem um amplo espectro de ação sobre aos microrganismos patogênicos e/ou deteriorantes, como Staphylococcus aureus e Salmonella spp., outras bactérias Gram positivas, fungos e leveduras, são resistentes a diversos tipos de tratamentos, não perdendo sua atividade em altas temperaturas, na presença de ácidos ou enzimas (LJUNGH; TORKEL, 2006; COGAN; ACCOLAS, 1996; NES; JOHNSBORG, 2004).

Estudos mostram que Lactococcus lactis produz uma bacteriocina denominada nisina, que inibe o crescimento de uma ampla variedade de bactérias Gram positivas, como a Listeria monocytogenes e Clostridium.

Há mais de 50 anos, a nisina tem sido utilizada como aditivo nas indústrias alimentícias em mais de 48 países (WALSTRA et al., 1999; CLEVELAND et al., 2001). Esta bacteriocina é reconhecida como segura (GRAS - Generally Recognized as Safe) e seu uso é liberado como aditivo alimentar pelo Comitê do Codex Alimentarius, da FAO, como agente antimicrobiano (MORENO et al., 2000b). No Brasil, seu uso é permitido em queijos fundidos, preparados à base de queijos fundidos, queijos pasteurizados e requeijão (BRASIL, 1996), no entanto, não pode 
ser usado como aditivo e coadjuvante de tecnologia de fabricação em bebidas lácteas (BRASIL, 2005).

Em carne bovina estéril inoculada com Listeria monocytogenes e Lactococcus lactis ssp. hordniae produtor de bacteriocina, houve redução e inibição de desenvolvimento do microrganismo patogênico. Além disso, a bacteriocina manteve sua atividade, após diferentes tipos de tratamentos térmicos (autoclavagem e refrigeração) e sob condições ácidas e alcalinas, possuindo maior atividade em menores valores de pH (BROMBERG et al., 2006). É importante ressaltar que a eficiência inibitória da nisina depende dos níveis de contaminação do alimento. Caso a contaminação inicial seja muito elevada, a atividade da nisina é restrita, não impedindo a deterioração do produto (MORENO; LERAYER; LEITÃO, 2008).

O aspecto favorável do uso de bacteriocinas, tal como a reuterina, produzida por $L$. reuteri, é a ausência de alterações no sabor quando aplicada nos alimentos (RODGERS, 2008). Rodgers (2008) realizaram um estudo sobre a aplicação de culturas protetoras produtoras de bacteriocinas em alimentos não fermentáveis (peixe ensopado, vegetais ao molho curry e frango guisado), adicionados com 1 - 2 g. $\mathrm{kg}^{-1}$ de culturas protetoras e realizaram uma análise sensorial. Os julgadores foram incapazes de distinguir os produtos que continham ou não as culturas.

Algumas classes de bacteriocinas são resistentes ao calor e podem ser adicionadas ao produto sem alteração no modo de preparo, além de serem fáceis de manusear e de armazenar. A desvantagem da adição de nisina é que esta bacteriocina é considerada um conservante químico, e a legislação brasileira preconiza o valor máximo permitido de $12,5 \mathrm{mg} \mathrm{kg}^{-1}$ (ANVISA, 1996).

Estudos mostram a produção de várias bacteriocinas e substâncias antibacterianas por L. acidophilus, tais quais lactocidina, acidolina, acidofilina, lactacium-B e proteínas inibidoras (SHAH, 2007).

Apesar da existência de vasta literatura sobre a atividade antimicrobiana das LAB sobre aos microrganismos patogênicos e/ou deteriorantes, muito pouco se conhece sobre essa ação sobre leveduras, uma vez que estas são responsáveis pelo comprometimento da qualidade de produtos lácteos fermentados. 


\subsection{Probióticos}

No final do século 19, os microbiologistas identificaram microrganismos presentes na microbiota intestinal de indivíduos saudáveis, os quais foram denominados de próbioticos (PARVEZ et al., 2006). O termo probiótico, derivado do grego, significa "para a vida" (SHAH, 2007). A Organização Mundial da Saúde definiu probióticos como microrganismos vivos, quando administrados em quantidade adequada, conferem benefícios à saúde do hospedeiro (FAO/WHO, 2002). No Brasil, o Regulamento Técnico de Substâncias Bioativas e Probióticas Isolados com Alegações de Propriedades Funcionais e/ou de Saúde da Resolução RDC $n^{\circ} 2$ de janeiro de 2002, os probióticos são definidos como microrganismos vivos que, ingeridos em certa quantidade, são capazes de melhorar o equilíbrio microbiano intestinal, produzindo efeitos benéficos à saúde do indivíduo (BRASIL, 2002).

As bactérias probióticas são constituídas por espécies láticas e bifidobactérias. Para que sejam consideradas probióticas, esses microrganismos devem satisfazer critérios, tais como: não patogênicos, sobreviver durante a passagem no trato gastrointestinal e manter-se no intestino por mais tempo do que as demais bactérias. Além disso, devem tolerar a acidez do estômago e os sais biliares presentes no intestino (OLIVEIRA; DAMIN, 2003; WALSTRA; WOUTERS; GEURTS, 2006). Diversos gêneros de bactérias láticas apresentam características de probióticos, incluindo Lactobacillus, Leuconostoc, Pediococcus, Bifidobacterium e Enterococcus, porém as principais espécies probióticas são L. acidophilus, Bifidobacterium animalis e L. casei (PIMENTEL; FRANCKI; GOLLUCKE, 2005, SHAH, 2007).

Há anos, os probióticos são consumidos pelos benefícios à saúde que proporcionam. Antes de 1900, os cientistas já tentavam desvendar as razões deste benefício (SHAH, 2007). Muito desses já são bem documentados; outros têm mostrado um potencial promissor em estudos com animais, sendo necessários estudos em humanos para substanciar essas afirmações. No entanto, os benefícios terapêuticos fornecidos pelos probióticos variam de acordo com a cepa, e não há uma cepa universal que forneça todos os benefícios já estudados (VASILJEVIC; $\mathrm{SHAH}, 2008)$. Os principais efeitos terapêuticos atribuídos ao consumo de probióticos, estudados por diversos autores (SAARELA, 2000; ROBINSON, 2002; 
THOMSEN, 2006; PARVEZ et al., 2006; WALSTRA; WOUTERS; GEURTS, 2006; SHAH, 2007; RODGERS, 2008; VASILJEVIC; SHAH, 2008; GUPTA; GARG, 2009) são:

- Aumento da resposta imune: aumento na produção de macrófagos e interleucinas e estimulação da produção de interferon Y;

- Equilíbrio da microbiota intestinal por competição pela mucosa e por nutrientes, habilidade de aderir e colonizar no intestino;

- Prevenção e redução da diarréia: diarréia decorrente do desenvolvimento de Clostridium difficile após tratamento com antibióticos, e da diarréia dos viajantes causada, principalmente, pela $E$. coli enterotoxigênica, e da diarréia causada por rotavírus;

- Efeitos antimutagênicos e anticarcinogênicos: redução da atividade de enzimas fecais ( $\beta$-glucuronidase, azoredutase e nitroredutase), envolvidas na ativação carcinogênica;

- Reduz a quantidade de Helicobacter pylori relacionada às úlceras gástricas e patógenos intestinais;

- Produção de substâncias antimicrobianas: ácidos orgânicos, bacteriocinas, peróxido de hidrogênio, que inibem a multiplicação de microrganismos patogênicos e deteriorantes, como Escherichia coli, Salmonella enterica Typhimurium, Staphylococcus aureus e Clostridium perfringens;

- Redução no nível do colesterol sérico: inibidores da síntese do colesterol, utilização do colesterol por assimilação e precipitação com sais biliares desconjugados;

- Alivia a intolerância à lactose: produção da enzima $\beta$-D-galactosidase pelas bactérias láticas em leites fermentados, que hidrolisam a lactose em glicose e galactose, resultando em menor teor de lactose nos produtos fermentados;

- Melhora a infecção por Candida e outras infecções do trato urinário;

- Previne as doenças inflamatórias no intestino.

É importante ressaltar os microrganismos probióticos contribui para o equilíbrio da flora intestinal, e seu consumo deve estar associado a uma alimentação equilibrada e hábitos de vida saudáveis (BRASIL, 2008).

Adicionalmente, o aumento no uso de culturas probióticas na fabricação de produtos fermentados tem melhorado a qualidade do produto final. A inativação de 
microrganismos indesejáveis pela acidificação e a presença de compostos antimicrobianos produzidos por essas culturas propicia ao produto, melhores propriedades físico-químicas, sensoriais e microbiológicas, oferecendo assim, um alimento conservado, seguro e com qualidade (KOS et al., 2008).

No entanto, para que as bactérias probióticas desempenhem benefícios aos seus consumidores, esses microrganismos devem ser viáveis e principalmente, disponíveis em altas concentrações $\left(10^{8}-10^{9} \mathrm{UFC} . \mathrm{g}^{-1}\right.$ / porção) durante toda a vida de prateleira do produto, além de serem capazes de transitar, sobreviver e aderir ao trato gastrointestinal. É também necessário que sejam capazes de aderir às células do epitélio intestinal e colonizarem o lúmen do trato, produzam substâncias antimicrobianas contra patógenos e estabilizem a microflora intestinal (PARVEZ et al., 2006, SHAH, 2007).

\subsubsection{Lactobacillus}

O gênero Lactobacillus é comumente utilizado como probiótico nos alimentos. É um grupo heterogêneo de microrganismos, sendo constituído por várias espécies e algumas sub-espécies. São ubíquos, Gram-positivos, incapazes de formar esporos, imóveis, geralmente são encontrados em pares ou cadeias, variando de cocobacilos a bacilos, sendo microaeróbios com crescimento ótimo em anaerobiose. Este gênero pode ser subdividido em dois grupos, baseados no metabolismo de carboidratos: homofermentativos (produzem predominantemente ácido lático) e heterofermentativos (produzindo dióxido de carbono, etanol, e/ou ácido acético e ácido lático). Necessitam de nutrientes complexos para seu crescimento, sendo assim, classificados como microrganismos fastidiosos. Possuem temperatura ótima de crescimento variando entre 30 a $40^{\circ} \mathrm{C}$, classificando-se como microrganismos mesófilos. São acidúricos, com pH ótimo de crescimento entre 5,5 - 6,2 (ROBINSON, 2002).

\subsubsection{Lactobacillus acidophilus}

Lactobacillus acidophilus foi isolado pela primeira vez pelo alemão TiesserMoro, a partir de fezes de lactentes, o qual recebeu o nome de Bacillus acidophilus. Posteriormente, foi denominado Lactobacillus acidophilus, e anos depois, por meio 
de estudos concluiu-se que este microrganismo possui a capacidade de colonizar o trato gastrointestinal proporcionando benefícios aos seus consumidores (VASILJEVIC; SHAH, 2008).

É descrito como cocobacilo, Gram-positivo, catalase-negativo, anaeróbio a microaerófilo, homofermentativo que produz nos leites fermentados e iogurtes elevada proporção de ácido lático na configuração DL. São imóveis, esporulantes, medindo de 0,6-0,9 $\mu \mathrm{m}$ de largura e 1,5-6,0 $\mu \mathrm{m}$ de comprimento, ocorrendo isoladamente, em pares ou formando pequenas cadeias, e as colônias são geralmente brancas. Estes microrganismos são fracos formadores de ácidos, crescendo em $\mathrm{pH}$ 6,4-4,5 e seu desenvolvimento é cessado quando o $\mathrm{pH}$ atinge entre 4,0-3,6. É pouco tolerante a ambientes salinos. Grande parte das cepas degrada amidalina, celobiose, esculina, frutose, galactose, glicose, lactose, maltose, manose e sacarose. Crescem em temperatura entre 20 a $48^{\circ} \mathrm{C}$, sendo a temperatura ótima de crescimento de 35-40ㄷ (FRANCO; LANDGRAF; DESTRO, 1996). Os lactobacilos contribuem com o sabor e aroma em alimentos fermentados, produzindo vários compostos voláteis, como o diacetil e seus derivados ( $\mathrm{SHAH}, 2001)$.

Diversos autores têm realizado estudos para averiguar a produção de compostos antimicrobianos por L. acidophilus. De Muynck e colaboradores (2004), ao utilizarem o teste de difusão em ágar com diferentes cepas de bactérias láticas sobre fungos deteriorantes, constatou que 13/18 (75\%) cepas utilizadas apresentaram alguma atividade antifúgica. Dentre essas, L. acidophilus LMG 9433, L. amylovorus DSM 20532, L. brevis LMG 6906 e L. coryniformis subsp. coryniformis LMG 9196, mostraram ser excelentes produtoras de metabólitos antifúngicos, não somente pelo efeito do baixo $\mathrm{pH}$, como também pela produção de outros metabólitos orgânicos.

Pereira e Gómez (2007) estudaram a natureza do composto inibidor produzido pela cepa Lactobacillus acidophilus La-5. A atividade antimicrobiana exercida por este microrganismo sobre E. coli e $S$. aureus foi provavelmente devida à presença do ácido lático e do baixo $\mathrm{pH}$.

Kos e colaboradores (2008) selecionaram cepas probióticas com potenciais para produção de culturas láticas: Enterococcus faecium L3, Lactobacillus plantarum L4 e Lactobacillus acidophilus M92. Nos estudos in vitro, utilizando o método de difusão em ágar foi constatado que estes microrganismos apresentaram efeito antimicrobiano sobre Salmonella enterica Typhimurium e Listeria monocytogenes. 


\subsubsection{Lactobacillus casei}

Lactobacillus casei é um microrganismo Gram-positivo, não esporulado, catalase negativo, em forma de bastonete, é facultativo quanto ao requerimento de oxigênio, ácido tolerante e estritamente fermentativo. É um habitante comum do intestino delgado, sendo resistente à bile e sua temperatura ótima de crescimento é de $37^{\circ} \mathrm{C}$. É um microrganismo homofermentativo facultativo, produzindo quase exclusivamente ácido lático, a partir da degradação da glicose via Embder-Meyerhof, embora possa produzir também acetaldeído. Não produz amônia a partir da arginina, fermenta glicose, galactose, manose e maltose, entretanto não fermenta rafinose e ramnose e a maioria das cepas fermenta a lactose em $L(+)$ lactato (RAVULA; SHAH, 1998; ALONSO; ISAY, 2007).

O uso de bactérias láticas como produtoras de compostos inibidores de crescimento para microrganismos deteriorantes têm sido exploradas intensamente. Yang e Clausen (2005) obtiveram em seus estudos uma redução de 95-100\% no crescimento de fungos filamentosos, quando em contato com Lactobacillus casei e Lactobacillus acidophilus. Além disso, ao separarem o sobrenadante, este apresentou 4 componentes desconhecidos que exibiram atividade antifúngica. Os metabólitos produzidos por estes microrganismos apresentaram resistência ao aquecimento a $121^{\circ} \mathrm{C} / 15$ minutos e atividade após serem neutralizados.

Osuntoki, Ejide e Omonigbehin (2008) isolaram espécies de Lactobacillus presentes em produtos lácteos fermentados e avaliaram a atividade inibitória sobre algumas espécies enteropatogênicas. L. casei apresentou ação inibitória mais eficiente sobre Listeria monocytogenes quando comparado com Salmonella enterica Typhimurium.

Em um estudo similar feito por Mishra e Prasad (2005), também foi constatada a presença de atividade inibitória in vitro de diferentes cepas de $L$. casei sobre microrganismos patogênicos, como S. typhi, S. dysenteriae e S. aureus. Foram utilizadas cepas probióticas e incorporadas em um produto lácteo regional da Índia.

Atanassova e colaboradores (2003) isolaram L. paracasei subsp. paracasei em um queijo amarelo produzido na Bulgária. O microrganismo em estudo apresentou atividade bactericida sobre: Bacillus subtilis, Helicobacter pylori, L. delbrueckii, Saccharomyces cerevisiae e espécies do grupo Candida. No entanto, $L$. 
paracasei subsp. paracasei não apresentou atividade antimicrobiana sobre Cryptococcus albidus var. aerius e Cryptococcus curvatus.

\subsection{Bebidas lácteas}

As bebidas lácteas começaram a ser produzidas a partir de 1992, apresentam características semelhantes ao iogurte líquido, diferindo apenas por apresentar em sua composição o soro de queijo, em quantidades que podem variar de $30 \%$ a $70 \%$ (SEIBEL; CANSIAN, 2000).

O Regulamento Técnico de Identidade e Qualidade de Bebidas Lácteas (BRASIL, 2005) especifica que bebida láctea é o produto obtido a partir de leite ou leite reconstituído e/ou derivados de leite reconstituído ou não, fermentado ou não, com ou sem adição de outros ingredientes, onde a base láctea represente pelo menos 51\% (massa/massa) do total de ingredientes do produto. O produto fermentado deve ainda ser processado mediante a ação de um cultivo de microrganismos específicos, e/ou outros produtos lácteos fermentados e não poderá ser submetido a tratamento térmico após a fermentação. A contagem total de bactérias láticas viáveis deve ser no mínimo $10^{6}$ UFC.g ${ }^{-1}$ no produto final para o cultivo lático específico empregado durante todo o prazo de validade. No entanto, a recomendação mínima diária para produtos lácteos probióticos, deve ser de $10^{8}$ a $10^{9}$ UFC. $\mathrm{mL}^{-1}$ (BRASIL, 2008). A legislação brasileira não estabelece um padrão para fungos filamentosos e leveduriformes (BRASIL, 2005).

Nos últimos anos, o consumo de bebidas lácteas fermentadas tem aumentado pela presença de proteínas, gorduras, lactose, minerais e vitaminas, e pela adição de probióticos. Com isso, o mercado de bebidas lácteas funcionais tem sido promissor. As bebidas lácteas são caracterizadas por possuírem baixa viscosidade, sendo consideradas bebidas suaves e refrescantes. As empresas, na tentativa de conquistar o paladar e a preferência do consumidor, têm buscando inovações por meio de sabores e aromas diferenciados, fórmulas aperfeiçoadas, acréscimo de nutrientes, embalagens mais atrativas e práticas. Além disso, as bebidas lácteas proporcionam 0 hábito no consumo de produtos lácteos fermentados, e soluciona o problema de descarte do soro, grande preocupação das indústrias de laticínios (MARCHIORI, 2006). 


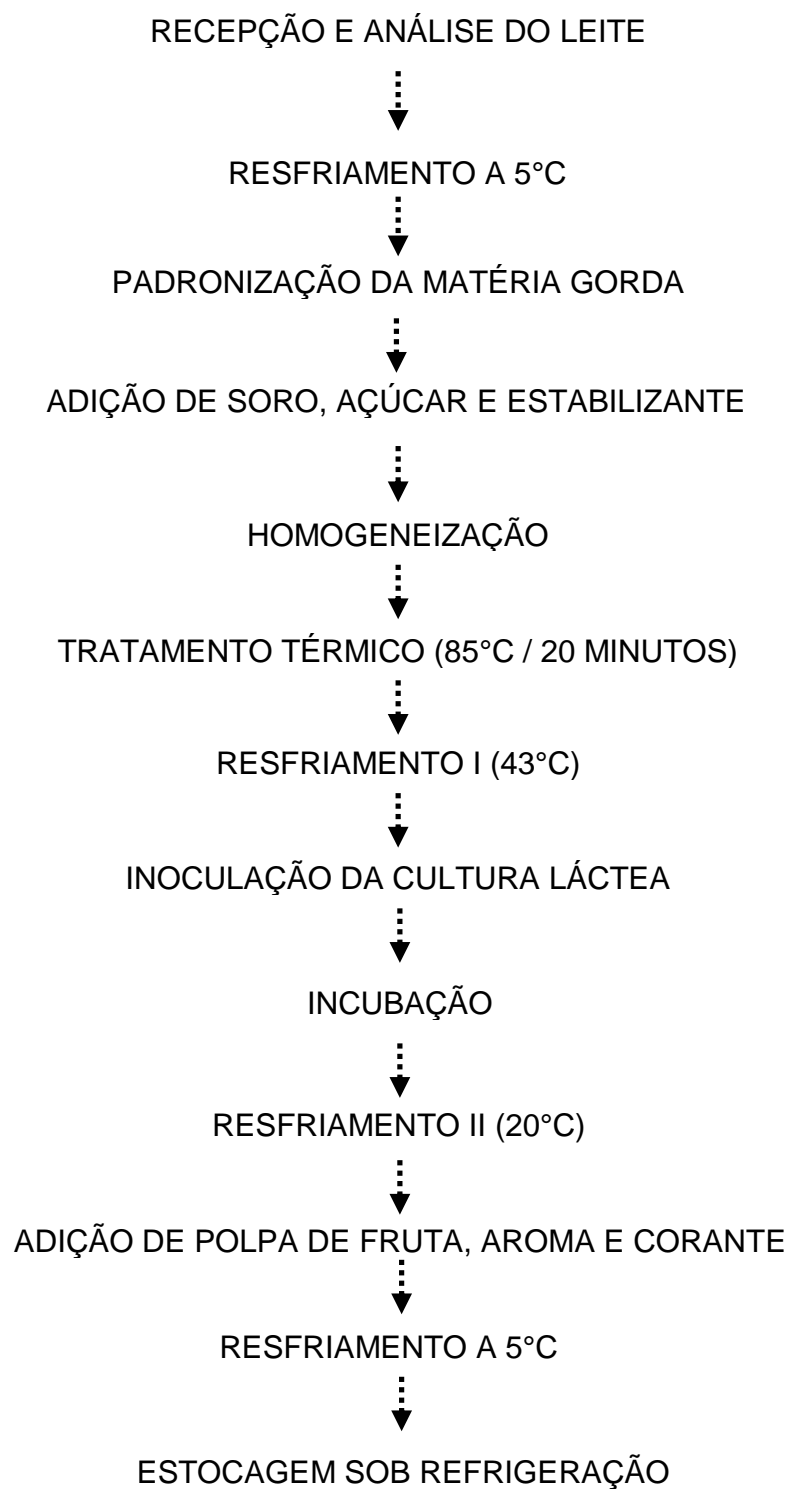

Figura 1 - Fluxograma de um processo de fabricação de bebidas lácteas fermentadas (MADUREIRA, 2004).

O processo de fabricação das bebidas lácteas é bastante simples, conforme ilustrado na Figura 1. Utiliza em grande parte os equipamentos disponíveis nas indústrias lácteas ou demandam pequeno investimento. Geralmente é baseado na mistura de soro ao leite antes do processo fermentativo ou o soro pasteurizado pode ser adicionado após o término da fermentação (LIMA; MADUREIRA; PENNA, 2002).

Estão disponíveis na literatura relatos de bebidas lácteas comerciais contaminadas, que não atendem os requisitos microbiológicos estabelecidos na legislação brasileira. Reis (2008) pode constatar inadequações ao analisar 31 amostras de bebidas lácteas de diferentes marcas disponíveis no mercado. Das 
amostras analisadas, 16,13\% não atenderam os padrões estabelecidos pela legislação em vigor. Os produtos avaliados apresentaram < 1 a 5,2 × $10^{9}$ UFC.mL ${ }^{-1}$ de bactérias aeróbias mesófilas, < 1 a 3,7 × $10^{9}$ UFC. $\mathrm{mL}^{-1}$ de fungos filamentosos e leveduriformes, 15 a > 1100 NMP de coliformes termotolerantes. $\mathrm{mL}^{-1}$ e ausência de Salmonella spp. em $25 \mathrm{~mL}$ de amostra. Por outro lado, estudos realizados por Hoffmann, Penna e Vinturim (1998), constataram que bebidas lácteas de diferentes marcas comerciais, encontravam-se de acordo com os padrões microbiológicos estabelecidos pela legislação em vigor. Foram realizadas contagens de bactérias aeróbias psicrotróficas, bactérias aeróbias mesófilas, bactérias aeróbias termófilas, S. aureus, coliformes termotolerantes e totais, Escherichia coli, Salmonella spp., fungos filamentosos e leveduriformes.

Do total de 14 amostras de bebidas lácteas fermentadas avaliadas por Rodrigues e Santos (2007), todas estavam de acordo com o padrão estabelecido para coliformes termotolerantes. Porém, $28,57 \%$ das amostras estavam contaminadas por fungos filamentosos e leveduriformes. Os autores também analisaram 39 amostras de iogurtes, constatando a presença de fungos filamentosos e leveduriformes em $53,84 \%$ das amostras e a presença de coliformes termotolerantes em 5,13\%.

A busca por um alimento livre de patógenos e/ ou deteriorantes é constante, no entanto, estudos comprovam que as doenças de origem alimentar e intoxicações alimentares ainda ocorrem com grande freqüência, causando sintomas como gastroenterites e diarréias, sendo um grande problema de saúde pública. As fontes de contaminação mais freqüentes na origem de surtos de doenças alimentares são: práticas inadequadas de manipulação, matérias-primas contaminadas, contaminação cruzada, falta de higiene durante a preparação, além de equipamentos e estrutura operacional deficiente (DUREK, 2005).

A incidência de contaminação em produtos comerciais demonstra a necessidade de implantação de programas visando garantir a segurança alimentar para a população, tais como as Boas Práticas de Fabricação (BPF) e Análise de Perigos e Pontos Críticos de Controle (APPCC), uma vez que os produtos de origem animal são altamente perecíveis e grandes veiculadores de doenças alimentares (DUREK, 2005).

As Boas Práticas de Fabricação seguem um conjunto de normas relacionadas aos ingredientes, aditivos e insumos, processos, serviços de suporte, edificações, 
armazenamento e expedição do produto. Tem como objetivo oferecer ao consumidor um produto de qualidade tecnológica e sanitária, além de aperfeiçoar a produção e aumentar o mercado consumidor. O APPCC avalia toda linha produtiva e estabelece sistemas de controle preventivo, com intuito de evitarem falhas na qualidade do produto durante todo seu processamento.

Aliada à implantação de programas de qualidade na produção de alimentos, a conservação biológica, com a aplicação de culturas protetoras, como as de bactérias láticas, pode proporcionar uma proteção adicional para melhorar a qualidade dos produtos lácteos.

\subsection{Leveduras}

As leveduras são microrganismos eucarióticos, fungos unicelulares, sendo classificadas como ascomicetos ou basidiomicetos. Geralmente são células esféricas, ovais ou cilíndricas e a divisão celular é binária. As leveduras são encontradas em produtos manufaturados que contêm gordura ou grande quantidade de açúcar, tais como os produtos lácteos (JACQUES; CASAREGOLA, 2008; MADIGAN; MARTINKO; PARKER, 2008).

Esses microrganismos estão presentes nos produtos lácteos pela ação de processos fermentativos, maturações ou deteriorações (JAKOBSEN; NARVHUS, 1996), podendo causar efeitos desejáveis ou indesejáveis.

Leveduras podem interagir com outros microrganismos presentes em produtos lácteos, por três diferentes meios: (i) inibem ou eliminam microrganismos indesejáveis ou patogênicos que podem causar defeitos na qualidade do produto, (ii) inibem a cultura iniciadora, (iii) contribuem positivamente no processo de fermentação e maturação dando suporte a cultura iniciadora (JAKOBSEN; NARVHUS, 1996).

O desenvolvimento de leveduras em produtos lácteos ocorre devido à capacidade desses microrganismos de tolerarem baixas temperaturas e acidez, assimilar/fermentar a lactose ou galactose, assimilar ácidos orgânicos, tais como o succinato, ácido lático e cítrico, possuírem atividade proteolítica e lipolítica sobre à caseína e à gordura presentes no leite, baixa atividade de água, resistência à salinidade e a desinfetantes (JACQUES; CASAREGOLA, 2008). 
As bactérias láticas que não fazem parte da cultura lática (non starter lactic acid bacteria - NSLAB), oriundas do leite ou do ambiente promovem diferentes características na fermentação de produtos lácteos, além de oferecerem um ambiente propício para o crescimento de leveduras (WOUTERS et al., 2002).

Um efeito sinergístico positivo é a presença de algumas leveduras na maturação de certos queijos e em alguns produtos lácteos fermentados. Conforme a Figura 2, as bactérias láticas produzem ácidos orgânicos, como o ácido lático e o cítrico. Por sua vez, as leveduras assimilam esses ácidos, formando álcool e $\mathrm{CO}_{2}$, aumentando assim o $\mathrm{pH}$, criando um microambiente favorável para o crescimento de outras bactérias na superfície do queijo, como Brevibacterium linens. Além disso, as leveduras ao metabolizarem o ácido lático liberam vitaminas, tais como vitamina $B$, ácido pantotênico, niacina, riboflavina e biotina, as quais são importantes para 0 desenvolvimento das bactérias láticas. As leveduras produzem também outros metabólitos, como ácidos graxos de cadeia curta, proteases, lipases e outros compostos importantes para o desenvolvimento de aroma no queijo, como o etanol, acetaldeído, etilacetato e etilbutirato (WELTHAGEN; VILJOEN, 1998; VILJOEN, 2001).

No entanto, poucos estudos relatam a protocooperação de bactérias láticas e leveduras, sendo ainda pouco compreendidos (FERREIRA; VILJOEN, 2003). Acredita-se que para esse efeito ocorrer, as leveduras precisam alcançar altas densidades celulares e devem competir e interagir com outros organismos presentes, principalmente as LABs (WOUTERS et al., 2002).

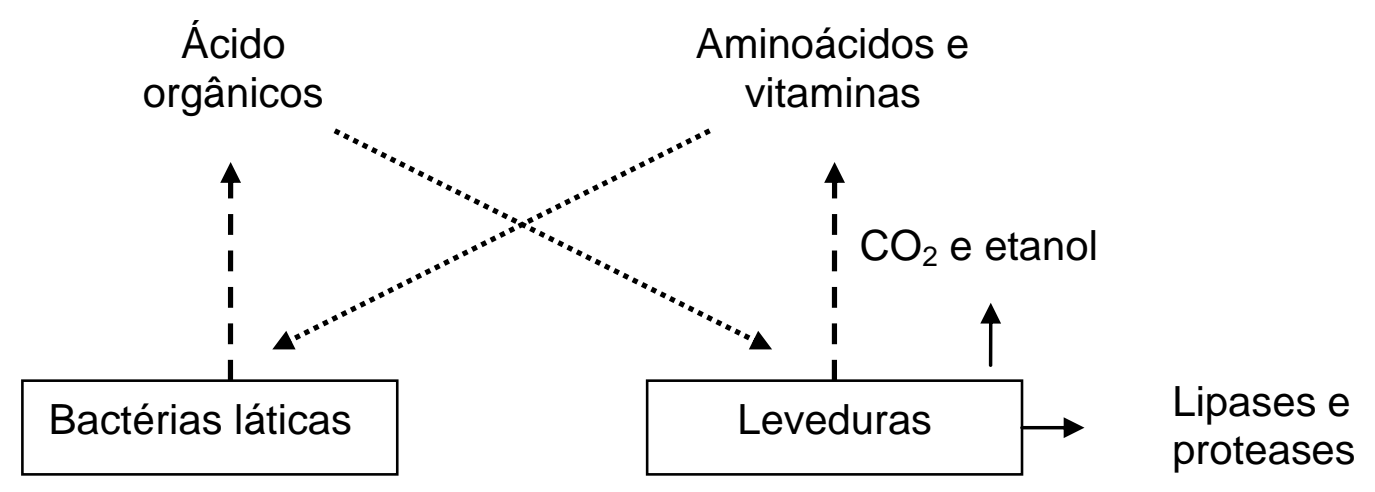

Figura 2 - Esquema de compostos metabólicos produzidos e assimilados por bactérias láticas e leveduras. 
Por outro lado, as interações negativas de leveduras com bactérias láticas em produtos lácteos fermentados podem levar a problemas econômicos e sensoriais. Deteriorações decorrentes de leveduras são particularmente comuns em produtos lácteos fermentados e em alguns queijos (JACQUES; CASAREGOLA, 2008). Kluyveromyces, Debaryomyces, Yarrowia e Candida são os gêneros de leveduras tipicamente encontradas em queijos, iogurtes e outros leites fermentados (ATANASSOVA et al., 2003). Candida edax, Cryptococcus laurentii, Cryptococcus albidus, e principalmente Debaryomyces hansenii foram encontradas em amostras queijo Minas Frescal, leite pasteurizado tipo A, B e C, bebida láctea, manteiga e ricota (MANSOR, 2001; SILVA, 2003; CARNICEL, 2004; GUSMÃO, 2005; REIS, 2008).

O crescimento excessivo de certas leveduras em produtos lácteos pode levar a formação de gases, sabores e odores desagradáveis, despigmentações, modificações na textura, formação de limo e sedimentos, e crescimento superficial, como D. hansenii e C. edax (ÁLVAREZ-MARTíN et al., 2008). Adicionalmente, algumas espécies de leveduras como $C$. albidus, $C$. laurentii são patógenos oportunistas, podendo ser capazes de causar diversos tipos de infecções em indivíduos susceptíveis, como os imunocomprometidos ou hospitalizados (JACQUES; CASAREGOLA, 2008).

Elevadas contaminações por leveduras são encontradas nas plantas de processamento. A presença desses microrganismos ocorre por várias fontes de contaminação, desde a obtenção da matéria-prima até o produto final. Diversos fatores tornam o ambiente de produção propício para o desenvolvimento de leveduras nos produtos lácteos, dentre eles, destacam-se: qualidade da matériaprima, condições de processamento, má higienização dos equipamentos, do ambiente, dos manipuladores, a eficiência da pasteurização, além de ingredientes, como polpas de frutas, mel, açúcar e castanhas (VILJOEN, 2001). Outro fator agravante é a resistência das leveduras aos sanitizantes comerciais e outros produtos de desinfecção. Laubscher e Viljoen (1999) isolaram culturas de leveduras presentes no queijo Cheddar: Candida versatilis, Candida rugosa, Debaryomyces hansenii, Dekkera custesiana, Rhodotorula mucilaginosa, Trichosporon beigelii, Torulaspora delbrueckii. As leveduras apresentaram resistência, após 60 min de exposição a todos os sanitizantes comerciais (clorinato, detergente ácido, detergente pasteurizado, sabonete germicida, detergente em pó, detergente alcalino, sanitizante 
iodopor, sanitizante ácido de peróxido,) comumente utilizados nas indústrias de processamento de queijos.

Leveduras resistentes a conservantes utilizados em bebidas lácteas foram avaliadas por Reis (2008). Foram isoladas de bebidas lácteas de diferentes sabores, 74 culturas de leveduras, Debaryomyces hansenii (71), Cryptococcus albidus (1), Cryptococcus laurentii (1), Candida edax (1). Constatou-se que entre as leveduras isoladas, $50 \%$ e 18,92\% apresentaram resistência a 0,40\% de benzoato de sódio e $0,40 \%$ de sorbato de potássio, respectivamente. Estas concentrações são maiores que aquelas permitidas pela legislação vigente (ASSOCIAÇÃO BRASILEIRA DAS INDÚSTRIAS DE ALIMENTAÇÃO - ABIA, 2003). O limite máximo permitido para sorbato de potássio e benzoato de sódio é de 0,20\% no produto final.

Viljoen e colaboradores (2003) verificaram a origem da contaminação por leveduras no processamento e na maturação de queijo azul. Durante todo o processamento do queijo, a presença de Debaryomyces hansenii foi relevante, sendo encontrada em equipamentos, Cryptococcus albidus em amostras do ar, e pequenas contagens de Candida spp. foram encontradas no ambiente de processamento.

Debaryomyces hansenii foi encontrada em todas as amostras coletadas durante a fabricação de queijo da Serra do Salitre, enquanto Cryptococcus laurentii foi encontrado apenas no coalho e Candida sp. somente no queijo (LIMA et al., 2009).

O uso do leite cru contaminado por mastite bovina (inflamação das glândulas mamárias) pode afetar a produção e a qualidade do leite e derivados. Diversos microrganismos podem estar envolvidos na mastite, dentre esses as leveduras (COSTA et al., 2008). Espécies dos gêneros Cryptococcus, Rhodotorula, Trichosporon e Candida têm sido isoladas em leite provenientes de animais acometidos por mastite. Costa e colaboradores (2008) coletaram amostras de leite bovino e detectaram que as leveduras encontradas apresentaram pouca expressão na etiologia da mastite dos rebanhos estudados, no entanto o gênero mais encontrado foi Candida spp. Se o leite nestas condições for utilizado pela indústria, e ocorrer falhas na pasteurização, a presença destes microrganismos poderá ser mantida até o produto final. Em contrapartida, sabe-se que as bactérias láticas produzem efeitos antimicrobianos sobre leveduras presentes em produtos lácteos 
fermentados, pela produção de ácidos orgânicos, antibióticos, peróxido de hidrogênio e bacteriocinas (ATASSANOVA et al., 2003).

Existem poucos estudos relacionados às propriedades antimicrobianas produzidas pelas LABs sobre fungos filamentosos e leveduriformes. Os fungos filamentosos podem deteriorar os alimentos e apresentar perigo à saúde humana devido à produção de micotoxinas. Em indivíduos imunocomprometidos ou hospitalizados, as leveduras podem colonizar o trato gastrointestinal e translocarem pela corrente sanguínea provocando infecções. O baixo valor de $\mathrm{pH}$ dos iogurtes e bebidas lácteas favorece o crescimento de leveduras, resultando na deterioração desses produtos lácteos fermentados (ATASSANOVA et al., 2003).

\subsubsection{Cryptococcus albidus e Cryptococcus laurentii}

Os microrganismos do gênero Cryptococcus são basiodiomicetos, saprófitos, capsulados podendo sobreviver em ambientes pobres em nutrientes, além de serem resistentes à dessecação. Podem ser isolados do ar, solo, resíduos orgânicos de animais, penas, flores, madeira em decomposição e alimentos, tais como queijos, frutas, vinho e feijão. Raramente são citados como patogênicos em humanos, no entanto, a incidência de infecção por este patogêno tem aumentado nos últimos 40 anos, sendo que Cryptococcus laurentii e Cryptococcus albidus juntos são responsáveis por $80 \%$ dos casos relatados. Podem causar infecções por meio de inalação de propágulos, desenvolvendo principalmente em indivíduos imunodeprimidos (KHAWCHAROENPORN; APISARNTHANARAK; MUNDY, 2007; PEDROSO; FERREIRA; CANDIDO, 2007).

Borelli e colaboradores (2006) identificaram as espécies de leveduras presentes na produção de queijos artesanais na região da Serra da Canastra e encontraram Cryptococcus albidus no fermento natural. Silva (2003), Mansor (2001), Reis (2008) identificaram C. laurentii e C. albidus ao analisarem amostras de queijo Minas Frescal, manteiga e bebida láctea, respectivamente.

\subsubsection{Candida edax}

Candida edax são fungos ascomicetos, geralmente isolados de solo (SUZUKI et al., 1999), produzem enzimas lipolíticas e proteolíticas, fermentam a lactose e 
utilizam o acido lático. No Brasil, o isotipo Stephanoascus smithiae é comumente encontrado. Trata-se de um microrganismo não patogênico, que assimila maltose, galactose, sacarose, citrato e fermenta maltose, glucose e galactose (KURTZMAN; FELL, 1998; PRACHYAKIJ et al., 2007). Por se tratar de um microrganismo característico de solos, cogita-se a possibilidade de sua transferência para plantas e delas para os frutos.

Como as bebidas lácteas fermentadas são acrescidas de polpas de frutas, provavelmente a presença da Candida edax no produto seja pelo uso de frutos contaminados (REIS, 2008).

Kavas e colaboradores (2006) investigaram a ocorrência e o tipo de leveduras presentes em queijos e iogurtes produzidos na região da Turquia. Foi encontrado Candida sp. em todos os produtos analisados.

\subsubsection{Debaryomyces hansenii}

Debaryomyces hansenii é um grupo heterogêneo, não patogênico, sendo osmo, halo e xerotolerantes, possuem habilidade de desenvolverem em baixas temperaturas e assimilam lactato, citrato e galactose. Produz enzimas lipolíticas e proteolíticas, as quais metabolizam a gordura e as proteínas do leite. Possui crescimento ótimo de $20-25{ }^{\circ} \mathrm{C}$, porém podem crescer entre $5-10{ }^{\circ} \mathrm{C}$ (BREUER; HARMS, 2006). Estas leveduras podem ser encontradas em ambientes com baixa atividade de água, tais como salino, além de carnes, queijos, vinhos, cerveja, frutas, solo e produtos com altas concentrações de açúcar (BARNETT, 2000). Além disso, acumulam lipídios em suas células e produzem compostos voláteis importantes no queijo, tais como ácidos, álcoois, carbonil e sulfatos.

Alguns estudos relatam que $D$. hansenii fornece fatores de crescimento para bactérias, tais como vitaminas (tiamina, ácido pantotênico, nicotínico, fólico e biotina) e aminoácidos (WOUTERS et al., 2002, BREUER; HARMS, 2006).

Debaryomyces hansenii sintetiza e tolera várias toxinas produzidas por outros microrganismos. Algumas cepas podem inibir o crescimento de microrganismos deteriorantes (fungos filamentosos) em efeito simbiótico com as LABs (WELTHAGEN; VILJOEN, 1999). Esse efeito inibitório é causado principalmente,

pelo abaixamento do $\mathrm{pH}$ por $\mathrm{LAB}$ e pela produção de álcool e $\mathrm{CO}_{2}$ por leveduras (BREUER; HARMS, 2006). Liu e Tsao (2009a) observaram que apesar do efeito 
inibitório ser dependente do tipo de fungo filamentoso e da quantidade de esporos, estudos comprovam que esta levedura possui capacidade antimicrobiana sobre os fungos filamentosos Aspergillus, Byssochlamys e Eurotium presentes em queijos e iogurtes armazenados sem refrigeração.

Debaryomyces hansenii é importante na maturação de alguns queijos. Características como tolerância por sal, desenvolvimento em baixas temperaturas, e a habilidade de usar ácido lático e cítrico como fontes de carbono fazem com que esse microrganismo consiga sobreviver neste tipo de ambiente (WELTHAGEN; VILJOEN, 1998). No entanto, a presença desses microrganismos em produtos lácteos fermentados pode causar odor desagradável (BREUER; HARMS, 2006). As contaminações em bebidas lácteas se dão por diversas origens, conforme já citado anteriormente.

Elgadi, Gardir e Dirar (2008) isolaram espécies de leveduras presentes no leite cru bovino. De acordo com a morfologia e testes bioquímicos realizados, dentre as espécies, foi constatada a presença Debaryomyces hansenii. 


\section{OBJETIVOS}

\subsection{Objetivo geral}

- Verificar a atividade antimicrobiana de duas culturas probióticas comerciais em bebidas lácteas fermentadas sobre leveduras isoladas de produtos lácteos.

\subsection{Objetivos específicos}

- Verificar a capacidade antimicrobiana in vitro de culturas probióticas de L. casei e L. acidophilus sobre leveduras previamente isoladas de bebidas lácteas fermentadas: Debaryomyces hansenii var. fabryii (12 culturas), Candida edax (1 cultura), Cryptococcus albidus (1 cultura) e Cryptococcus laurentii (1 cultura).

- Desenvolver bebidas lácteas fermentadas por probióticos $L$. acidophilus e $L$. casei e verificar o efeito antimicrobiano no produto (in situ). 


\section{MATERIAL E MÉTODOS}

\subsection{Culturas de bactérias láticas}

Foram utilizadas duas culturas de bactérias láticas (LAB) de ação probiótica: Lactobacillus casei (Lc-1) e Lactobacillus acidophilus (La-5), fornecidas pela Christian Hansen ${ }^{\circledR}$ (Valinhos, Brasil).

As culturas para processamento industrial (25,0 gramas), liofilizadas e de uso direto, foram suspendidas assepticamente em 1000,0 mL de leite, previamente submetido à esterilização em autoclave (121ํㄷ, 1 atm/15 minutos). Em seguida, 0 leite estéril inoculado com as culturas foi distribuído em tubos de ensaio esterilizados, adicionados de glicerol (100\%) estéril como crioprotetor, e posteriormente mantidos em congelador a $-18^{\circ} \mathrm{C}$.

$\mathrm{Na}$ ocasião do uso, cada cultura probiótica foi retirada do congelamento e mantida a temperatura ambiente por 20 minutos.

\subsubsection{Viabilidade das culturas de bactérias láticas}

Foi transferido assepticamente $1,0 \mathrm{~mL}$ da cultura descongelada para tubos de ensaio contendo 9,0 mL de caldo MRS (Acumedia) com maltose (Merck) para Lactobacillus acidophilus e 9,0 mL de caldo MRS acidificado até $\mathrm{pH}$ 5,4 para Lactobacillus casei incubados a $37^{\circ} \mathrm{C}$ por 24,48 e 72 horas, em aerobiose e em jarras de anaerobiose (Anaerobac, $\mathrm{PROBAC}^{\circledR}$ ), respectivamente, conforme IDF (1995), IDF (1997) e Balduíno, Oliveira e Hauly (1999), com modificações.

Após cada período de incubação, foram feitas as diluições decimais seriadas até $10^{-10}$ com peptona bacteriológica estéril a $0,1 \%$ (Himedia). Posteriormente, para a determinação da viabilidade dos microrganismos, $1,0 \mathrm{~mL}$ de cada cultivo foi inoculado por profundidade, em duplicata, em placas contendo o ágar MRS com maltose para La-5 e MRS acidificado até $\mathrm{pH} 5,4$ para Lc-1. As placas foram incubadas a $37^{\circ} \mathrm{C}$ por $72 \mathrm{~h}$ em aerobiose e anaerobiose, para Lactobacillus acidophilus e Lactobacillus casei, respectivamente (OSTLIE; HELLAND; NARVHUS, 2003). 
A leitura foi feita com auxílio de um contador de colônias e multiplicada pela recíproca da diluição, sendo o resultado expresso como número de unidades formadoras de colônias por mililitro (UFC. $\mathrm{mL}^{-1}$ ).

\subsubsection{Obtenção do sobrenadante livre de células probióticas}

Cada cultura probiótica ativada foi transferida na proporção $10,0 \%\left(10^{11}-10^{13}\right.$ UFC. $\mathrm{mL}^{-1}$ ) para um frasco de Erlenmeyer contendo caldo MRS acidificado até $\mathrm{pH}$ 5,4 para $L$. casei e caldo MRS com maltose para $L$. acidophilus e incubadas a $37^{\circ} \mathrm{C}$ por 72 horas, em anaerobiose (IDF, 1997; BALDUÍNO; OLIVEIRA; HAULY, 1999; IDF, 1995). Após o período de incubação, o caldo foi centrifugado a $12.317 \mathrm{~g}$ x por 10 minutos. Em seguida, o sobrenadante foi concentrado 5 vezes aproximadamente, no evaporador rotativo, a $55^{\circ} \mathrm{C}$. O sobrenadante obtido e seu concentrado foram utilizados para avaliar o comportamento antimicrobiano in vitro (PRADO et al., 2000; NARDI et al., 2005). Em paralelo, para avaliar a natureza do composto inibidor, o sobrenadante livre de células e seu concentrado foram neutralizados de $\mathrm{pH}$ 3,8 para cerca de 6,8 - 7,0, com solução de $\mathrm{NaOH} 1 \mathrm{~N}$.

\subsection{Culturas de leveduras}

Foram utilizadas as leveduras: Debaryomyces hansenii var. fabryii (12 culturas), Candida edax (1 cultura), Cryptococcus albidus (1 cultura) e Cryptococcus laurentii (1 cultura), previamente isoladas de bebidas lácteas fermentadas comerciais e caracterizadas por Reis (2008), de acordo com a Tabela 1. As culturas selecionadas para o presente estudo foram aquelas que se mostraram resistentes ao dobro da concentração dos conservantes permitidos pela legislação vigente, ou seja, $0,4 \%$ de benzoato de sódio e $0,4 \%$ de sorbato de potássio, testadas in vitro, totalizando 15 culturas das 74 isoladas.

Cada cultura possui um código de identificação $B L_{n, n 1}$, em que $B L$ = bebida láctea fermentada com adição de polpas de frutas, $n=$ número da amostra e $n 1=$ número da cepa isolada. As cepas encontram-se estocadas em tubos de ensaio contendo 7,0 mL de meio Gymp (2,0\% de glicose (Synth), 0,5\% de extrato de levedura (Himedia), 1,0\% de extrato de malte (Himedia), 0,2\% de $\mathrm{NaH}_{2} \mathrm{PO}_{4}$ (Synth), 
e 2,0\% de ágar (Acumedia) e posteriormente, cobertas com óleo mineral estéril para evitar ressecamento, sendo mantidas a $8 \pm 2^{\circ} \mathrm{C}$.

As leveduras foram semeadas em tubos de ensaio contendo 9,0 $\mathrm{mL}$ de caldo MPL (Meio para levedura: 2,0\% de glicose, 0,5\% de extrato de levedura, 1,0\% de cloreto de sódio (Synth),, 0,23\% de fosfato de sódio monobásico e 0,5\% de sulfato de amônio (Synth) e incubadas por a 25드 por 120 horas (REIS, 2008).

Tabela 1 - Distribuição das espécies de leveduras utilizadas e identificação da amostra de origem.

\begin{tabular}{|c|c|c|c|}
\hline Espécies & $\begin{array}{l}\text { Códigos das } \\
\text { leveduras }\end{array}$ & $\begin{array}{c}\text { Números de } \\
\text { culturas }\end{array}$ & $\begin{array}{l}\text { Porcentagens } \\
\qquad(n=15)\end{array}$ \\
\hline $\begin{array}{l}\text { Debaryomyces } \\
\text { hansenii var. fabryii }\end{array}$ & $\begin{array}{l}\mathrm{BL}_{20,13} ; \mathrm{BL}_{21,2} ; \mathrm{BL}_{21,3} ; \\
\mathrm{BL}_{21,4} ; \mathrm{BL}_{22,1} ; \mathrm{BL}_{22,2} ; \\
\mathrm{BL}_{22,3} ; \mathrm{BL}_{22,4} ; \mathrm{BL}_{22,5} ; \\
\mathrm{BL}_{22,6} ; \mathrm{BL}_{22,7} ; \mathrm{BL}_{22,8}\end{array}$ & 12 & $80,0 \%$ \\
\hline Candida edax & $\mathrm{BL}_{20,16}$ & 1 & $6,6 \%$ \\
\hline Cryptococcus. albidus & $\mathrm{BL}_{6,1}$ & 1 & $6,6 \%$ \\
\hline Cryptococcus. laurentii & $\mathrm{BL}_{12,2}$ & 1 & $6,6 \%$ \\
\hline
\end{tabular}

\subsubsection{Viabilidade das culturas de leveduras}

Em testes preliminares, após a ativação das culturas, foi feita a determinação da densidade populacional das leveduras empregando-se o método de contagem em placa. Foram feitas diluições decimais seriadas até $10^{-10}$ UFC. $\mathrm{mL}^{-1}$ e inoculação em profundidade em ágar MPL, e incubação a 25ํㅡ com leituras após 12, 24, 36, 48 e 120 horas, segundo Mufandaedza e colaboradores (2006), com modificações. Este teste teve o objetivo de verificar qual o tempo de incubação necessário para atingir $10^{4}$ UFC. $\mathrm{mL}^{-1}$ de leveduras, para posterior análise do comportamento antimicrobiano in vitro. Esta densidade populacional foi definida a partir da média entre os valores obtidos no estudo realizado por Reis (2008), de < 1 a 3,7 × $10^{9}$ UFC. $\mathrm{mL}^{-1}$.

Para se efetuar o desenvolvimento das leveduras, após a contagem em placa, uma colônia de cada levedura foi isolada e semeada em tubos de ensaio contendo 
9,0 mL de caldo MPL e incubada pelo tempo necessário para atingir $10^{4}$ UFC. $\mathrm{mL}^{-1}$. Após a incubação, foi confirmada a viabilidade dos microrganismos, utilizando método de cultura em profundidade, em ágar MPL, incubação a 25ํㅡ por 5 dias.

\subsection{Planejamento dos experimentos}

Para o estudo da capacidade antimicrobiana in vitro foram utilizadas 15 culturas de leveduras, 2 culturas de bactérias láticas em diferentes testes. Teste 1) células probióticas, Teste 2) sobrenadante livre de células, sobrenadante livre de células concentrado, Teste 3) sobrenadante livre de células neutralizado e sobrenadante livre de células concentrado neutralizado, em duplicata, totalizando 180 experimentos, conforme esquema apresentado na Figura 3.

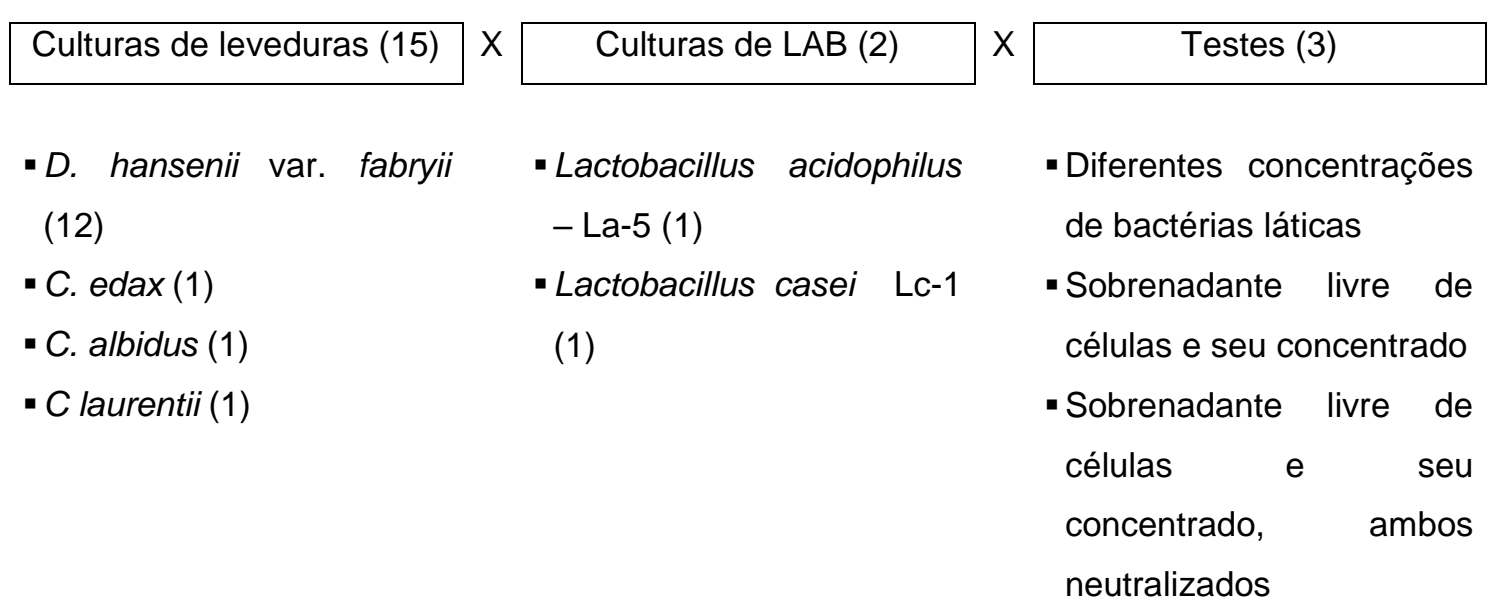

Figura 3 - Planejamento dos experimentos a partir do estudo do comportamento antimicrobiano in vitro, em duplicata.

\subsubsection{Capacidade antimicrobiana in vitro}

Para avaliar a atividade antimicrobiana foi utilizado o teste de perfuração e difusão em ágar, segundo Schillinger e Lücke (1989), com modificações.

Foram feitos três testes (Tabela 2), os quais um inóculo de $10^{-4} \mathrm{UFC} \cdot \mathrm{mL}^{-1}$ de cada uma das culturas de leveduras ativadas foram inoculadas por profundidade em meio MPL, acrescidos de $2,0 \%$ de ágar. Após solidificação, as placas foram incubadas a $25^{\circ} \mathrm{C}$ por 24 horas. Após a incubação, as placas foram divididas em 
quatro quadrantes, nos quais foi efetuada uma perfuração ("poço") de 9,0 mm de diâmetro. Em cada perfuração foi feita a inoculação de alíquotas de 400,0 $\mu \mathrm{L}$ da cultura de células probióticas, sobrenadante livre de células probióticas, sobrenadante concentrado, sobrenadante livre de células neutralizado e sobrenadante concentrado neutralizado, conforme ilustrado na Tabela 2.

Em seguida, as placas foram incubadas sob refrigeração $\left(7^{\circ} \mathrm{C}\right)$ por 24 horas para difusão do sobrenadante e das células probióticas no ágar. Este procedimento foi efetuado (em duplicata) para as culturas de leveduras (15 culturas) de modo a interagir, positiva ou negativamente, com as diferentes concentrações de cada uma das culturas probióticas (Lactobacillus acidophilus e Lactobacillus casei).

As placas com as células de bactérias láticas foram incubadas a $37^{\circ} \mathrm{C}$, sob anaerobiose para Lactobacillus acidophilus e Lactobacillus casei, com leituras de 24, 48, 72 horas. Em paralelo, as placas com o sobrenadante livre de células e seu concentrado e o sobrenandante livre de células e seu concentrado neutralizado foram incubadas à temperatura de $25^{\circ} \mathrm{C}$ por 24 e 48 horas.

Tabela 2 - Testes realizados para avaliar a capacidade antimicrobiana.

\begin{tabular}{lccc}
\hline Quadrantes & Teste $1^{\mathrm{a}}$ & Teste $2^{\mathrm{b}}$ & Teste $^{\mathrm{c}}$ \\
\hline $1^{0}$ & $10^{6}$ UFC. $\mathrm{mL}^{-1}$ & SLC & SLCN \\
$2^{\circ}$ & $10^{8}$ UFC. $\mathrm{mL}^{-1}$ & SLC & SLCN \\
$3^{\circ}$ & $10^{10}$ UFC. $\mathrm{mL}^{-1}$ & SLCC & SLCCN \\
$4^{\circ}$ & $10^{12}$ UFC. $\mathrm{mL}^{-1}$ & SLCC & SLCCN \\
\hline
\end{tabular}

a - Diferentes concentrações de células de bactérias láticas; b - Sobrenadante livre de células e seu concentrado; c - Sobrenadante livre de células e seu concentrado, ambos neutralizados. SLC sobrenadante livre de células; SLCC - sobrenadante livre de células concentrado; SLCN sobrenadante livre de células neutralizado; SLCCN - sobrenadante livre de células concentrado neutralizado.

\subsection{Preparação da bebida láctea fermentada}

As leveduras que apresentaram sensibilidade sobre as bactérias láticas no estudo in vitro foram testadas para confirmação do efeito antimicrobiano na bebida láctea fermentada.

Conforme ilustrado na Figura 4, em cada processamento as bebidas lácteas foram preparadas, a partir de leite integral em pó (Itambé®) $(70,0 \%)$ e soro de leite 
(Alibra) em pó (30,0\%) para compor aproximadamente 10,0\% de sólidos totais. Os ingredientes foram pesados e misturados na forma seca e reconstituídos em água a $60^{\circ} \mathrm{C}$, em quantidade suficiente para preparar cerca de $400,0 \mathrm{~mL}$ de bebida láctea. Esta mistura foi submetida à esterilização a $121^{\circ} \mathrm{C}$ por 15 minutos, seguida de resfriamento a $42^{\circ} \mathrm{C}$. A mistura de leite e soro foi inoculada com $0,1 \%$ de cultura lática probiótica $\left(10^{10}\right.$ UFC. $\left.\mathrm{mL}^{-1}\right)$ e $0,25 \%$ de inóculo da levedura $\left(10^{4}\right.$ UFC. $\left.\mathrm{mL}^{-1}\right)$, em condições assépticas, conforme o experimento (ÁLVAREZ-MARTíN et al., 2008). Foram feitos processamentos controle, sem a adição da cultura de levedura.

$\mathrm{O}$ produto foi incubado a $43^{\circ} \mathrm{C}$ em banho termostatizado. $\mathrm{O}$ tempo de fermentação da bebida láctea foi calculado a partir do início da inoculação, até obterse o valor de $\mathrm{pH}$ próximo a 4,6. Foi feito um controle e registro do $\mathrm{pH}$ durante toda a fermentação para o cálculo da cinética de acidificação do meio. Terminada a fermentação, o produto foi resfriado inicialmente a $20^{\circ} \mathrm{C}$, seguida de quebra do coágulo por agitação manual durante 2 minutos, de forma padronizada para todos os experimentos, e resfriado a $5^{\circ} \mathrm{C}$. O produto foi embalado em frascos estéreis com capacidade para $50 \mathrm{~mL}$ e armazenado a $5^{\circ} \mathrm{C}$ para posterior análise. 
LEITE INTEGRAL EM PÓ (70\%) + SORO DE LEITE EM PO (30\%)

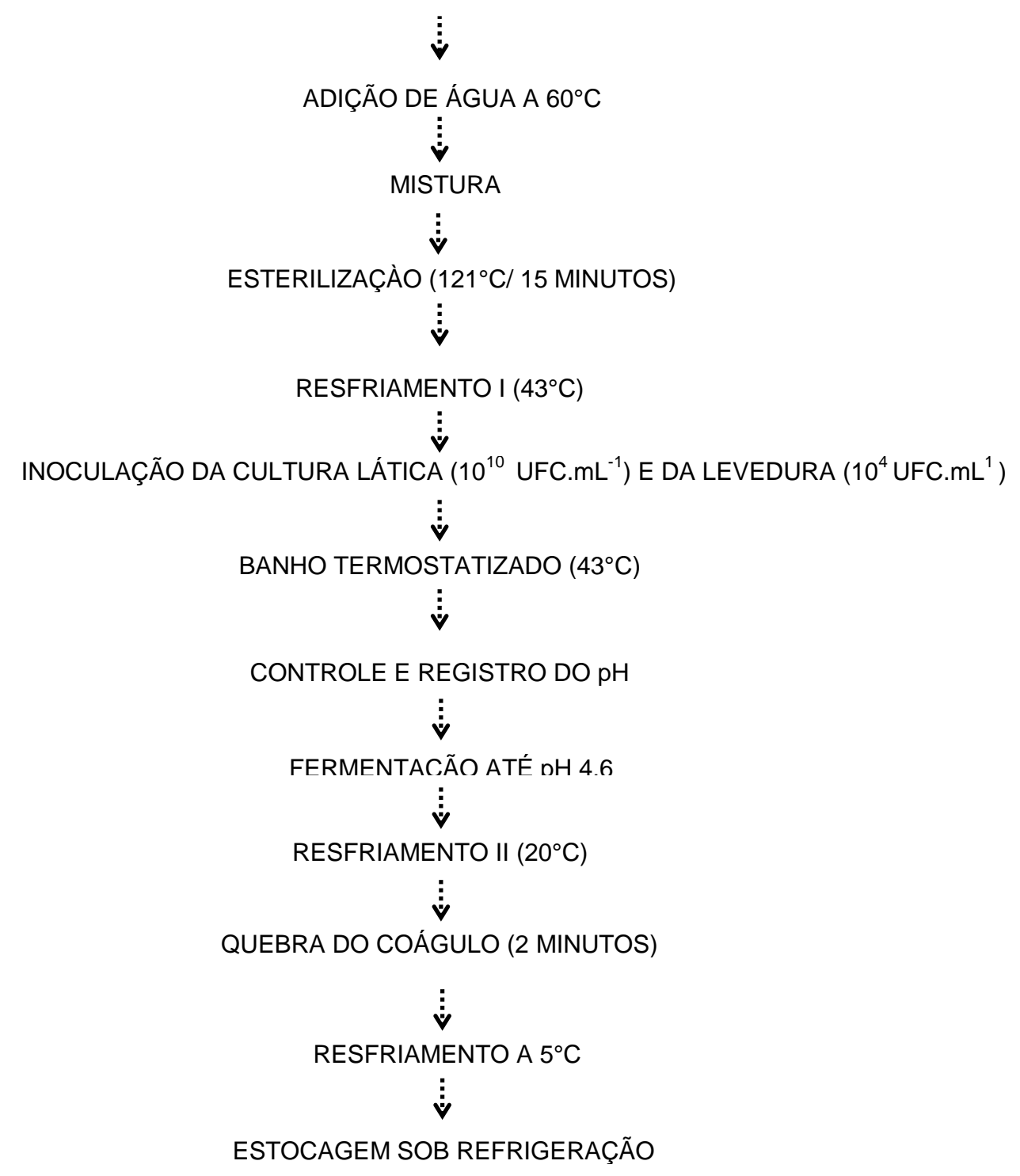

Figura 4 - Fluxograma de um processo de fabricação de bebidas lácteas fermentadas.

\subsection{Avaliação da bebida láctea fermentada}

\subsubsection{Análises físico-químicas}

As bebidas lácteas foram submetidas às análises físico-químicas descritas a seguir:

- Teor de sólidos totais: foi determinado por meio da secagem da amostra em estufa a vácuo, a 70ํㅡ por 24 horas (CASE; BRADLEY JUNIOR; WILLIAMS, 1985); 
- Valor de pH e tempo de fermentação: durante a fermentação foi feita a determinação e registro do valor de $\mathrm{pH}$ das bebidas lácteas usando-se potenciômetro digital portátil acoplado a um registrador (INSTITUTO ADOLFO LUTZ - IAL, 2008), até atingir o pH de aproximadamente 4,6, quando também foi registrado o tempo de fermentação;

- Acidez titulável: as determinações dos teores de acidez expressas em ${ }^{\circ}$ Dornic foram realizadas por meio da titulação ácido-alcalimétrica, usando-se fenolftaleína como indicador (IAL, 2008).

\subsubsection{Viabilidade das bactérias láticas e das leveduras no produto}

A avaliação da viabilidade dos microrganismos nas amostras de bebidas lácteas preparadas foi feita a partir de diluições decimais seriadas. Dez mililitros da amostra foram transferidos de forma asséptica para um frasco de Erlenmeyer estéril contendo $90,0 \mathrm{~mL}$ de água peptonada 0,1\%. Essa diluição foi agitada vigorosamente e, em seguida, foram feitas as diluições decimais seriadas utilizando-se o mesmo diluente e inoculações por profundidade em meios seletivos para a contagem dos microrganismos:

- Lactobacillus acidophilus e Lactobacillus casei: foram utilizados, respectivamente, os seguintes ágar: MRS com maltose e MRS acidificado até $\mathrm{pH} 5,4$, respectivamente. As placas foram incubadas a $37^{\circ} \mathrm{C}$ por $72 \mathrm{~h}$ em anaerobiose, para Lactobacillus acidophilus e Lactobacillus casei, (IDF, 1995; IDF, 1997).

- Fungos filamentosos e leveduriformes: foi utilizado placas de Compact Dry® YM (Nissui Pharmaceutical Co., Ltd., Tokyo, Japan), incubadas a 25ํㅡ por 120 horas.

\subsection{Avaliação da bebida láctea fermentada durante a vida de prateleira}

O comportamento de pós-acidificação ( $\mathrm{pH}$ e acidez titulável) e a viabilidade da microbiota, citadas nos itens 4.5.1 e 4.5.2. foram avaliadas a cada 20 dias, por 60 dias, para verificar possíveis alterações durante a armazenagem refrigerada a $5^{\circ} \mathrm{C}$. 


\subsection{Análise estatística dos resultados experimentais}

Foi feita a análise da variância (ANOVA) dos resultados da capacidade antimicrobiana e da avaliação físico-química e microbiológica das bebidas lácteas fermentadas e a comparação entre as médias pelo Teste de Tukey, considerando-se um nível de significância $p<0,05$, utilizando o programa computacional Assistat (SILVA; AZEVEDO, 2009). 


\section{RESULTADOS E DISCUSSÃO}

\subsection{Capacidade antimicrobiana de Lactobacillus acidophilus e Lactobacillus casei}

\subsubsection{Lactobacillus acidophilus (La-5)}

\subsubsection{Teste 1: Células probióticas}

No Teste 1, foi avaliado a atividade antimicrobiana das células probióticas de La-5. Nenhum dos inóculos celulares mostraram capacidade antimicrobiana sobre as leveduras, conforme a Figura 5. Células bacterianas freqüentemente comunicam por meio de mecanismos de sensor de quorum, que envolvem o sensoriamento da densidade populacional e o reconhecimento dependente de um auto-indutor excretado no meio ambiente, seguido por mudanças na expressão genética (BUCK; AZCARATE-PERIL; KLAENHAMMER, 2009; KIM et al., 2008). As bactérias Gram positivas de mesma espécie respondem a sinais captados do meio ambiente, tais como as bacteriocinas, e à medida em que a densidade populacional aumenta, a quantidade desses compostos liberados também aumenta, podendo promover um efeito indesejável em espécies diferentes (MADIGAN; MARTINKO; PARKER, 2008). Provavelmente, as células probióticas não obtiveram densidades populacionais elevadas o suficiente para a liberação de compostos inibidores que pudessem resultar no efeito antimicrobiano. Além disso, o composto antimicrobiano pode não ter sido de origem bacteriocinogênica. A competição por nutrientes, temperatura pode ter interferido no desenvolvimento da cultura probiótica e a difusão dos compostos antimicrobianos no ágar pode ter afetado a formação de halos de inibição.

Pan e colaboradores (2009) desenvolveram estudos relacionados à atividade antimicrobiana de L. acidophilus NIT, isolada de fezes de lactentes. Foram realizados três testes: com as culturas fermentadas, sobrenadante livre de células neutralizado e tratado com catalase, e células ressuspensas em caldo MRS. A atividade antimicrobiana foi avaliada por meio da metodologia de perfuração e difusão em ágar, de forma semelhante à realizada no presente estudo. Os patógenos testados: Escherichia coli, Salmonella enterica Typhimurium, Bacteroides 
vulgatus, Clostridium difficile tiveram forte inibição na presença de células probióticas, exceto Clostridium histolyticum.

Kos e colaboradores (2008) utilizaram em seus estudos cepas de Enterococcus faecium, Lactobacillus plantarum e Lactobacillus acidophilus isolados de silagem, repolho branco e leite fermentado. Por meio do método de perfuração e difusão em ágar, as culturas fermentadas e o sobrenadante livre de células apresentaram atividade antibacteriana sobre as bactérias Gram negativas e Gram positivas. Não houve atividade antimicrobiana após o sobrenadante concentrado 5 vezes ser neutralizado, demonstrando que o composto inibidor era de natureza ácida.

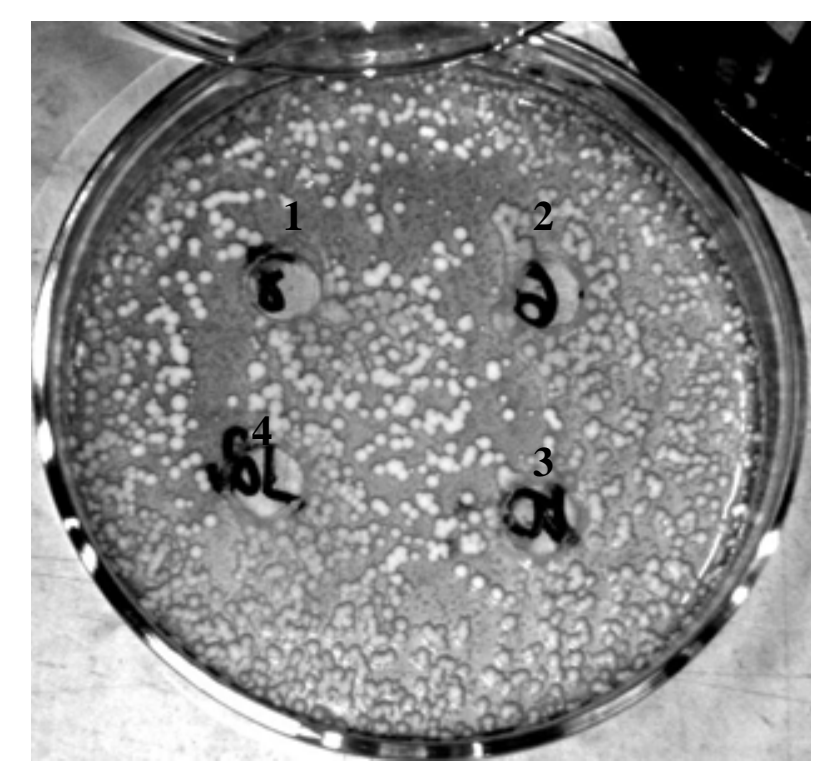

Figura 5 - Fotografia de placa com ágar MPL mostrando a atividade antimicrobiana das células de La- 5 sobre Debaryomyces hansenii, nas concentrações $10^{6} \mathrm{UFC} \cdot \mathrm{mL}^{-1}$ (1), $10^{8}$ UFC. $\mathrm{mL}^{-1}$ (2), $10^{10} \mathrm{UFC} \cdot \mathrm{mL}^{-1}$ (3), $10^{12} \mathrm{UFC} \cdot \mathrm{mL}^{-1}$ (4). Não houve formação de halos de inibição sobre a levedura.

\subsubsection{Teste 2: Sobrenadante livre de células e seu concentrado}

As vias de fermentação da glicose mais utilizadas por bactérias láticas homo e heterofermentativas são: a glicólise e a fosfocetolase (MADIGAN; MARTINKO; PARKER, 2008). Por essas vias são formados e secretados diversos compostos orgânicos com propriedades antimicrobianas. Dentre esses, destacam-se: ácido 
acético, lático, propiônico, diacetil, succinato e bacteriocinas (DE MUYNCK et al., 2004). Com o propósito de trabalharmos com os produtos secretados pelas culturas probióticas foi utilizado o sobrenadante livre de células e seu concentrado, os quais foram inoculados pelo método de perfuração e difusão em ágar.

Inicialmente, em testes preliminares foi determinado um inóculo de $200 \mathrm{uL}$ para o sobrenadante livre de células. No entanto, nessa concentração não houve atividade antimicrobiano desses produtos sobre leveduras. Sendo assim, aumentouse o inóculo para $400 \mathrm{uL}$ e concentrou-e o sobrenadante, pois a inibição ocorreu de forma pouco evidente quando a concentração não foi realizada. Segundo Pereira e Gómez (2007), o efeito inibidor de um microrganismo depende da concentração da substância inibidora presente.

No Teste 2, foi avaliado a atividade antimicrobiana do sobrenadante livre de células e seu concentrado. Os compostos secretados pela cultura La-5 mostrou atividade antimicrobiana somente para Cryptococcus albidus, com halos de inibição variando entre 2,9 $\mathrm{mm}$ a 3,1 $\mathrm{mm}$ para o sobrenadante livre de células e 6,9 $\mathrm{mm}$ a $7,4 \mathrm{~mm}$ para o sobrenadante livre de células concentrado (Tabela 3). A formação dos halos de inibição foram maiores no sobrenadante livre de células concentrado $(7,4 \mathrm{~mm})$ quando comparado com o não concentrado $(3,1 \mathrm{~mm})$, sendo estatisticamente diferentes entre si $(p<0,05)$. Apesar dos sobrenandantes se difundirem de modo similar no ágar, a concentração do sobrenadante influenciou nos resultados mostrando que o efeito inibidor foi potencializado após ser concentrado. Além disso, o sobrenadante livre de células concentrado não foi sensível ao calor e ao tempo exposto para concentrar-se no evaporador rotativo, 55 ${ }^{\circ} \mathrm{C}$ durante 30 minutos. Após 48 horas houve um aumento dos halos para ambos os tratamentos, porém não significativo estatisticamente $(p<0,05)$. O teste mostrou inibição completa no sobrenadante livre de células e no seu concentrado, conforme a Figura 6. Neste estudo, também foram visualizados halos de protocooperação entre $L$. acidophilus e Debaryomyces hannsenii, que serão discutidos posteriormente.

Pereira e Gómez (2007) utilizaram a metodologia de multicamadas e 0 método de difusão em ágar para verificar a atividade inibidora de L. acidophilus La-5 sobre Escherichia coli e Staphylococcus aureus. No estudo foram feitos vários testes para verificar a natureza do composto inibidor. A capacidade de inibir os microrganismos patogênicos foi extinta após a neutralização do sobrenadante livre 
de células com $\mathrm{NaOH} 1 \mathrm{~N}$. Devido às características metabólicas da bactéria lática, a substância que produziu o efeito antimicrobiano sobre os microrganismos patogênicos, provavelmente foi o ácido lático.

Tabela 3 - Atividade antimicrobiana do sobrenadante livre de células e seu concentrado de Lactobacillus acidophilus La-5, obtido pelo método de perfuração e difusão em ágar. Valores dos halos de inibição em $\mathrm{mm}$.

\begin{tabular}{|c|c|c|c|c|}
\hline \multirow[t]{2}{*}{ Leveduras } & \multicolumn{2}{|c|}{ Após 24h } & \multicolumn{2}{|c|}{ Após 48h } \\
\hline & SLC & SLCC & SLC & SLCC \\
\hline Cryptococcus albidus & $2,9^{\mathrm{Ab}} \pm 0,2$ & $6,9^{\mathrm{Ba}} \pm 0,8$ & $3,1^{\mathrm{Ab}} \pm 0,2$ & $7,4^{\mathrm{Ba}} \pm 0,7$ \\
\hline Cryptococcus laurentii & - & - & - & - \\
\hline Candida edax & - & - & - & - \\
\hline Debaryomyces hansenii & - & - & - & - \\
\hline \multicolumn{5}{|c|}{ Média e desvio padrão dos halos. A análise foi realizada em duplicata. } \\
\hline \multicolumn{5}{|c|}{ a, betras iguais na mesma linha indicam que não há diferença significativa $(p<0,05)$. } \\
\hline \multicolumn{5}{|c|}{$\begin{array}{l}\text { A, B Letras iguais na mesma coluna indicam que não há diferença significativa }(p<0,05) \text {. Comparação } \\
\text { com a Tabela } 4 .\end{array}$} \\
\hline \multicolumn{5}{|c|}{$\begin{array}{l}\text { (-) Ausência de halo de inibição; SLC - sobrenadante livre de células; SLCC - sobrenadante livre de } \\
\text { células concentrado }\end{array}$} \\
\hline
\end{tabular}

Yang e Clausen (2005) testaram as propriedades antimicrobianas de L. casei subsp. rhamnosus e $L$. acidophilus sobre fungos filamentosos que colonizam madeiras nos Estados Unidos. Foram encontradas inibições (90-99\%) sobre os fungos filamentosos: Trichoderma viride, Aspergillus niger, Penicillium chrysogenum e Aureobasidium pullulans. O sobrenadante livre de células de ambas as culturas probióticas produziram pelo menos quatro componentes desconhecidos que exibiram atividade antifúngica. Os metabólitos foram resistentes ao aquecimento $\left(121^{\circ} \mathrm{C}\right)$ e mantiveram sua atividade após serem neutralizados. 


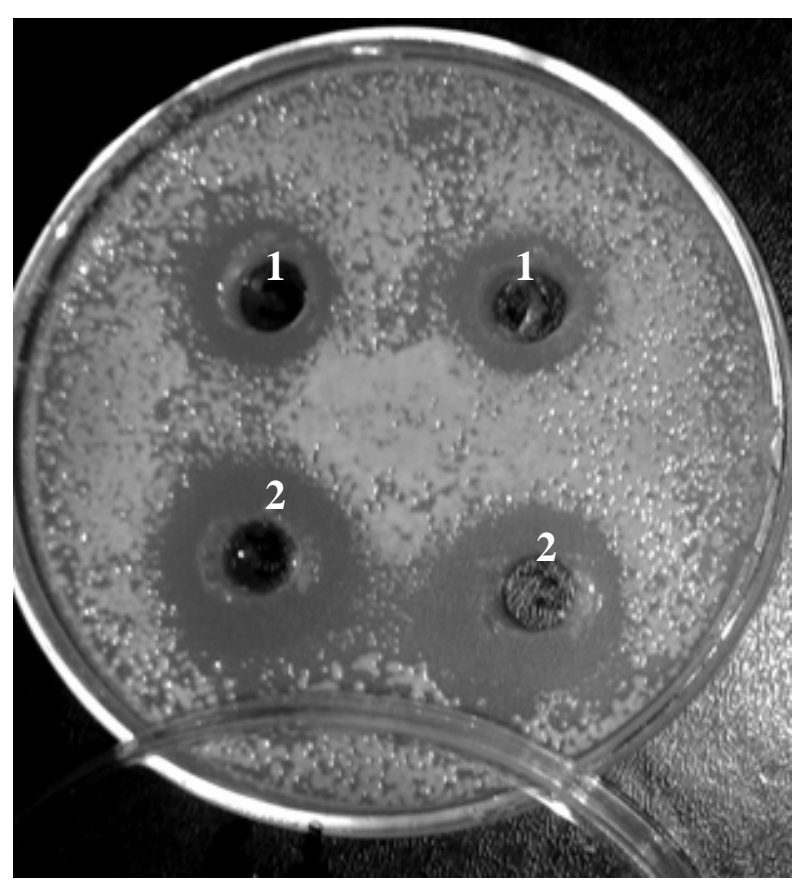

Figura 6 - Fotografia de placa com ágar MPL mostrando o efeito antimicrobiano do sobrenadante livre de células (1) e sobrenadante livre de células concentrado (2) de La-5 sobre Cryptococcus albidus. Houve formação de halos de inibição sobre a levedura.

Um estudo realizado por De Muynck e colaboradores (2004) com diversas espécies de culturas láticas probióticas, dentre elas L. acidophilus LMG 9433 e $L$. casei subsp. casei LMG 6904, constatou que usando o método de difusão em ágar, $72 \%$ (13/18) das culturas de bactérias láticas apresentaram atividade antifúngica, a qual variou de acordo com o estágio de desenvolvimento de cada cultura. $L$. acidophilus mostrou atividade antimicrobiana, especialmente para cepas de Penicillium. A neutralização do sobrenadante livre de células mostrou que nenhuma das leveduras foram inibidas, demonstrando que os ácidos orgânicos, ou outros compostos ácidos foram responsáveis pelo efeito antifúngico. L. casei não apresentou atividade antifúngica.

\subsubsection{Teste 3: Sobrenadante livre de células e seu concentrado neutralizados}

No Teste 3, foi avaliada a atividade antimicrobiana do sobrenadante livre de células e seu concentrado neutralizados. Na maioria dos casos a atividade 
antimicrobiana é inibida pela neutralização do sobrenadante livre de células e seu concentrado, demonstrando que o efeito inibidor é derivado de ácidos orgânicos. No entanto, no presente estudo após a neutralização do sobrenadante livre de células e seu concentrado, foi possível visualizar a formação de halos de inibição para $L$. acidophilus, medindo respectivamente entre $2,25 \mathrm{~mm}$ a $16,5 \mathrm{~mm}$ sobre Cryptococcus albidus, apresentando diferenças significativas entre os tratamentos $(p<0,05)$, conforme a Tabela 4. Além disso, de acordo com Reis (2008), as leveduras em estudo são ácido- tolerantes, logo o composto inibidor produzido pelas bactérias láticas não deve ser de natureza ácida.

Foi feita uma comparação entre os testes 2 e 3 . O sobrenadante livre de células concentrado (Tabela 3) mostrou menor halo de inibição quando comparado com o sobrenadante concentrado neutralizado de La-5 (Tabela 4), mostrando diferenças significativas entre os tratamentos $(p<0,05)$. O mesmo não foi constatado para o sobrenadante livre de células e seu neutralizado, o qual não houve diferenças significativas entre os tratamentos $(p<0,05)$. Uma vez que $C$. albidus necessita de um ácido para seu desenvolvimento a ausência do ácido no sobrenadante concentrado neutralizado, provavelmente, inibiu o crescimento desse microrganismo, resultando em maior halo de inibição.

Tabela 4 - Atividade antimicrobiana do sobrenadante livre de célula e seu concentrado neutralizado de Lactobacillus acidophilus La-5, obtido pelo método de perfuração e difusão em ágar. Valores dos halos de inibição em mm.

\begin{tabular}{lcccc}
\hline Leveduras & \multicolumn{2}{c}{ Após 24h } & \multicolumn{2}{c}{ Após 48h } \\
\cline { 2 - 5 } & SLCN & SLCCN & SLCN & SLCCN \\
\hline Cryptococcus albidus & $2,25^{\mathrm{AD}} \pm 0,3$ & $16,5^{\mathrm{Aa}} \pm 0,6$ & $2,25^{\mathrm{AD}} \pm 0,3$ & $16,5^{\mathrm{Aa}} \pm 0,3$ \\
Cryptococcus laurentii & - & - & - & - \\
Candida edax & - & - & - & - \\
Debaryomyces hansenii & - & - & - & -
\end{tabular}

Média e desvio padrão dos halos. A análise foi realizada em duplicata.

a, $b$ Letras iguais na mesma linha indicam que não há diferença significativa $(p<0,05)$.

$A, B$ Letras iguais na mesma coluna indicam que não há diferença significativa $(p<0,05)$. Comparação com a Tabela 3.

(-) Ausência de halo de inibição; SLCN - sobrenadante livre de células neutralizado; SLCCN sobrenadante livre de células concentrado neutralizado. 
Halos de protocooperação sobre todas as culturas de Debaryomyces hansenii não foram constatados após a neutralização do sobrenadante livre de células e seu concentrado de La-5. Esses resultados mostram que os ácidos orgânicos produzidos por La-5 são assimilados por D. hansenii. Halos de inibição sobre Candida edax e Cryptococcus laurentii não foram visualizados. O uso de diferentes amostras da cultura probiótica La-5 pode resultar em diferenças na viabilidade da cultura lática, além de outros fatores, como as condições de refrigeração e descongelamento (KOS et al., 2008).

No presente estudo, é pouco provável que a propriedade antifúngica de La-5 sobre $C$. albidus seja decorrente de ácidos orgânicos, peróxido de hidrogênio ou outros compostos ácidos, pois após a neutralização do sobrenadante e do crescimento da cultura probiótica em anaerobise, a fim de excluir o efeito inibidor de ácidos orgânicos e peróxido de hidrogênio (SCHULZ et al., 2003), não houve inibição do efeito antimicrobiano de La-5 sobre Cryptococcus albidus (Figura 7). No presente estudo, a natureza do composto, ainda é desconhecida. Estudos complementares serão necessários para identificar sua natureza.

Poucos estudos relatam a atividade antimicrobiana de La-5 sobre microrganismos patogênicos ou deteriorantes. Pereira e Gómes (2007) ao realizarem este estudo, relataram que o efeito inibidor foi, provavelmente, derivado de ácidos orgânicos. 


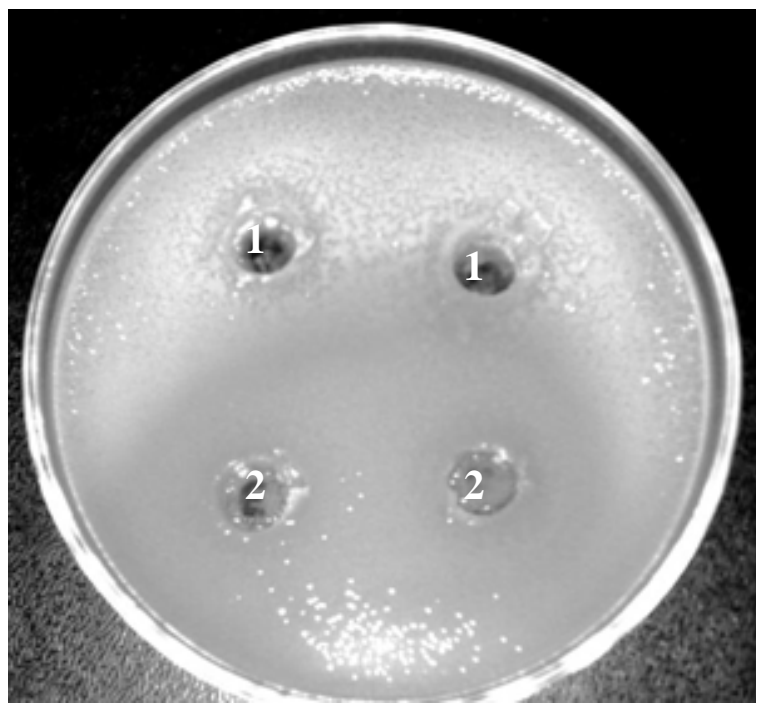

Figura 7 - Fotografia de placa com ágar MPL mostrando o efeito antimicrobiano do sobrenadante livre de células (1) e sobrenadante livre de células neutralizados (2) de La-5 sobre Cryptococcus albidus. Houve formação de halos de inibição sobre a levedura.

\subsubsection{Lactobacillus casei (Lc-1)}

\subsubsection{Teste 1: Células probióticas}

No Teste 1, foi avaliado a atividade antimicrobiana das células probióticas Lc1. Assim como em La-5, nenhuma das concentrações celulares utilizadas apresentaram atividade antimicrobiana sobre as leveduras testadas, conforme a Figura 8.

Poucos são os estudos com atividade antimicrobiana relacionados com células probióticas Lc-1 e leveduras como deteriorantes. 


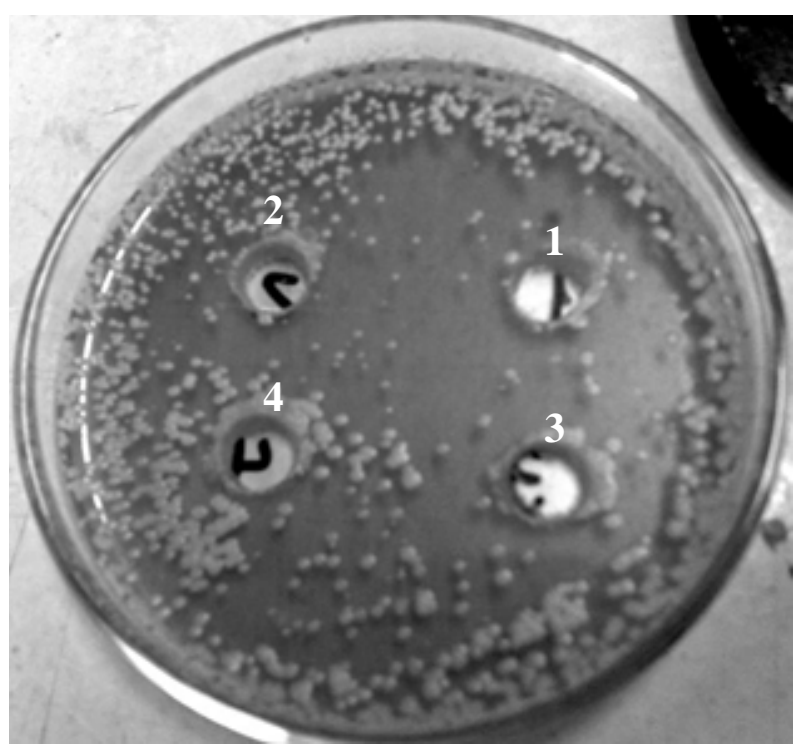

Figura 8 - Fotografia de placa com ágar MPL mostrando a atividade antimicrobiana das células de Lc-1 sobre Debaryomyces hansenii, nas concentrações $10^{6} \mathrm{UFC}$. $\mathrm{mL}^{-1}$ (1), $10^{8}$ UFC. $\mathrm{mL}^{-1}$ (2), $10^{10} \mathrm{UFC} \cdot \mathrm{mL}^{-1}$ (3), $10^{12} \mathrm{UFC} \cdot \mathrm{mL}^{-1}$ (4). Não houve formação de halos de inibição sobre a levedura.

\subsubsection{Teste 2: Sobrenadante livre de células e seu concentrado}

No Teste 2, foi avaliado a atividade antimicrobiana do sobrenadante livre de célula e seu concentrado. A cultura probiótica Lc-1 mostrou atividade antimicrobiana sobre $C$. albidus e $C$. laurentii com halos de inibição variando, entre $4,5 \mathrm{~mm}$ a $10 \mathrm{~mm}$ para o sobrenadante livre de células e $4,75 \mathrm{~mm}$ a $11 \mathrm{~mm}$ para o sobrenadante livre de células concentrado (Tabela 5). Halos de inibição para $C$. albidus apresentaram diferenças significativas $(p<0,05)$ apenas no sobrenadante livre de células, após 24 h. Não houve diferença significativa $(p<0,05)$ nos halos de inibição para $C$. laurentii, após $24 \mathrm{~h}$ e $48 \mathrm{~h}$. A diferença no tamanho dos halos pode ocorrer, pois a inibição de um microrganismo depende do grau de sensibilidade e da concentração da substância inibidora presente (ATANASSOVA et al., 2003). Provavelmente, C. albidus mostrou maior sensibilidade aos compostos orgânicos produzidos por LC-1.

Os resultados mostraram inibição completa para C. albidus (Figura 9) e para C. laurentii (Figura 10). Após 48 horas, o sobrenadante concentrado de algumas leveduras, Candida edax e duas culturas Debaryomyces hansenii, apresentaram um leve halo de inibição, com redução no crescimento destes microrganismos ao redor 
dos poços (dados não apresentados). Essas estirpes, possivelmente foram mais sensíveis aos compostos produzidos por Lc-1 do que as outras que não apresentaram nenhuma sensibilidade. O composto inibidor concentrado não resultou em maior formação de halos de inibição nas culturas de Cryptococcus. Halos de protocooperação entre Debaryomyces hansenii e L. casei foram visualizados neste estudo, que serão discutidos posteriormente.

Tabela 5 - Atividade antimicrobiana do sobrenadante livre de células e seu concentrado de Lactobacillus casei Lc-1, obtido pelo método de perfuração e difusão em ágar. Valores dos halos de inibição em $\mathrm{mm}$.

\begin{tabular}{lcccc}
\hline Leveduras & \multicolumn{2}{c}{ após 24h } & \multicolumn{2}{c}{ após 48h } \\
\cline { 2 - 5 } & SLC & SLCC & SLC & SLCC \\
\hline Cryptococcus albidus & $6,5^{\mathrm{Ab}} \pm 3,5$ & $10,25^{\mathrm{Aa}} \pm 1,1$ & $10^{\mathrm{Aa}} \pm 0$ & $11^{\mathrm{Aa}} \pm 1,4$ \\
Cryptococcus laurentii & $4,5^{\mathrm{Ba}} \pm 0,7$ & $4,75^{\mathrm{Ba}} \pm 1,5$ & $6,7^{\mathrm{Ba}} \pm 1,5$ & $6,8^{\mathrm{Ba}} \pm 1,0$ \\
Candida edax & - & - & - & - \\
Debaryomyces hansenii & - & - & - & - \\
\hline
\end{tabular}

Média e desvio padrão dos halos. A análise foi realizada em duplicata.

a, b Letras iguais na mesma linha indicam que não há diferença significativa $(p<0,05)$.

A, $B$ Letras iguais na mesma coluna indicam que não há diferença significativa $(p<0,05)$. Comparação com a Tabela 6.

(-) Ausência de halo de inibição; SLC - sobrenadante livre de células; SLCC - sobrenadante livre de células concentrado. 


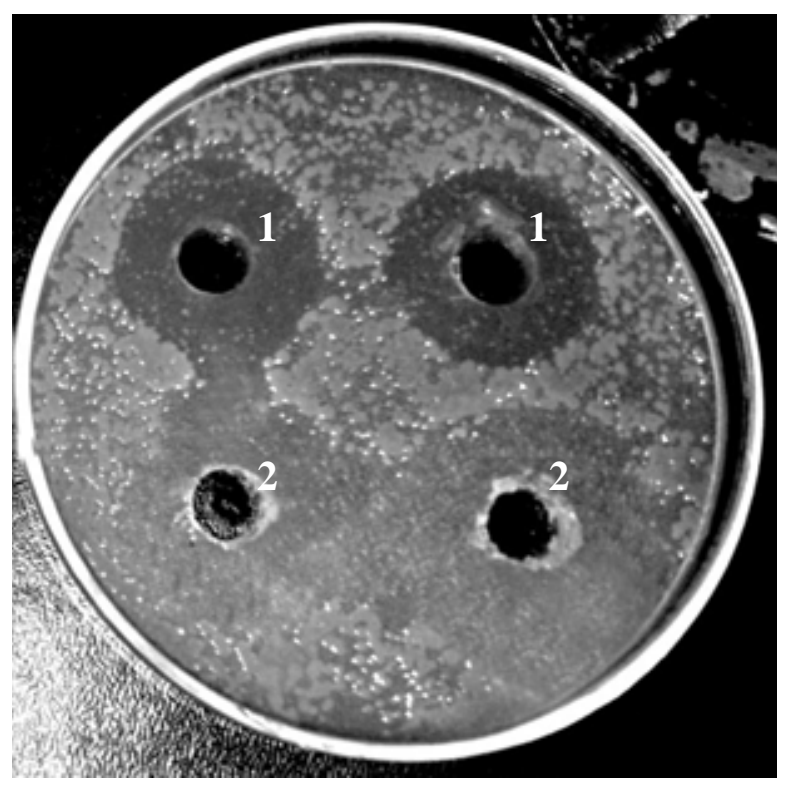

Figura 9 - Fotografia de placa com ágar MPL mostrando o efeito antimicrobiano do sobrenadante livre de células (1) e sobrenadante livre de células concentrado (2) de Lc-1 sobre Cryptococcus albidus. Houve formação de halos de inibição sobre a levedura.

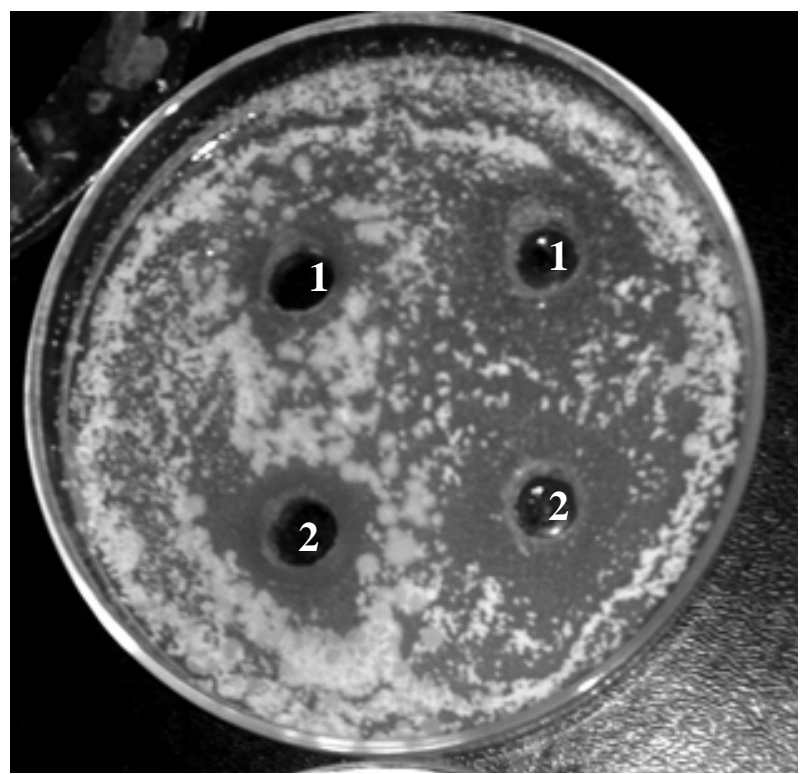

Figura 10 - Fotografia de placa com ágar MPL mostrando o efeito antimicrobiano do sobrenadante livre de células (1) e sobrenadante livre de células concentrado (2) de Lc-1 sobre Cryptococcus laurentii. Houve formação de halos de inibição sobre a levedura. 
Em estudos semelhantes, realizados por Misha e Prasad (2005), foram utilizadas sete culturas de $L$. casei e constatou-se que duas cepas probióticas produziram substâncias antimicrobianas que inibiram Salmonella enterica Typhimurium, com formação de halos. Além disso, uma das cepas apresentou resultados satisfatórios para todos os patógenos testados, Salmonella enterica Typhimurium, Bacillus cereus, Escherichia coli, Staphylococcus aureus e Shigella dysenteriae. No estudo, a atividade antimicrobiana foi atribuída à produção de ácidos orgânicos, sem especificar qual o ácido.

Volgari e colaboradores (2010) testaram a atividade antifúngica de oitenta e uma cepas de bactérias láticas isoladas da superfície de queijos duros, dentre elas L. paracasei subsp. paracasei. Nenhuma cepa apresentou atividade antimicrobiana sobre a Saccharomyces cerevisiae. O fungo filamentoso Penicillium sp. M1 sofreu inibição de todas as cepas probióticas: Enterococcus hirae, L. bulgaricus, L. paracasei subsp. paracasei e Leuconostoc sp, enquanto os fungos Penicillium sp. MT1, D. hansenii e $P$. candidum sofreram inibição de todas as culturas láticas relatadas, exceto por L. bulgaricus. A substância extracelular com efeito antimicrobiano foi sensível às enzimas proteolíticas, sugerindo que o efeito inibidor foi provavelmente devido à presença de bacteriocina. No presente estudo, a cultura probiótica Lc-1 não produziu substância antimicrobiana capaz de inibir Debaryomyces hansenii e Candida edax.

\subsubsection{Teste 3: Sobrenadante livre de células e seu concentrado neutralizado}

No Teste 3, foi avaliado a atividade antimicrobiana do sobrenadante livre de células e seu concentrado neutralizados. Os resultados mostraram que não houve a formação de halos de inibição no sobrenadante livre de células neutralizado, após 24 e 48 h para $C$. albidus e $C$. laurentii. $C$. laurentii também não apresentou halos de inibição no sobrenadante concentrado neutralizado, ao contrário de $C$. albidus que apresentou halos, após 24 e 48 h medindo 2,4 mm, não apresentando diferença significativa entre o tamanho dos halos $(p<0,05)$, conforme a Tabela 6 . Os mecanismos de inibição para as culturas probióticas La-5 e Lc-1 são diferentes, sendo assim, se o composto inibidor for de natureza protéica para ambas as culturas probióticas, provavelmente as seqüências peptídicas são diferentes. Caso a 
natureza do composto antimicrobiano produzido por Lc-1 não for de natureza ácida, provavelmente quando o sobrenadante livre de células concentrado foi neutralizado o peptídeo ativo, tornou-se inativo, perdendo assim sua função inibidora e apresentando halos de inibição menores quando comparado com o Teste 2.

Assim como na cultura La-5, halos de protocooperação entre L. casei e Debaryomyces hansenii não foram visualizados após a neutralização dos sobrenadante livre de células e seu concentrado, demonstrando que o composto formado é de natureza ácida. Não houve a formação de halos de inibição na cultura de Candida edax.

O sobrenadante livre de células concentrado, Tabela 5, apresentou maiores halos de inibição, quando comparado com 0 sobrenadante concentrado neutralizado, Tabela 6, apresentando diferenças significativas em todos os tratamentos $(p<0,05)$. Provavelmente, o composto antimicrobiano é de natureza ácida. A avaliação completa da natureza do composto inibidor poderá melhor esclarecer o comportamento observado.

Hutt e colaboradores (2006) estudaram a atividade antimicrobiana de $L$. acidophilus (La-5), L. fermentum, L. plantarum, L. paracasei, Bifidobacterium lactis (Bb-12) e Bifidobacterium longum. Utilizando a metodologia de estriamento em placa, no sobrenadante neutralizado nenhum efeito inibidor foi encontrado sobre as bactérias Gram negativas anaeróbias facultativas. Drago e colaboradores (1997) não encontraram atividade no sobrenadante livre de células neutralizado de $L$. acidophilus e L. paracasei. Provavelmente, a substância antimicrobiana é derivada de ácidos.

Utilizando L. paracasei isolados de um queijo amarelo típico da Bulgária, Atanassova e colaboradores (2003) conseguiram inibir o crescimento de Bacillus subtilis, Helicobacter pylori, Lactobacillus delbrueckii, Candida albicans, Candida blankii, Candida pseudointermedia e Saccharomyces. cerevisiae. Foi utilizado o método de perfuração e difusão em ágar, no qual os microrganismos patogênicos e deteriorantes foram adicionados em profundidade e superfície. Foram adicionados $100 \mu \mathrm{L}$ do sobrenadante neutralizado livre de células nos poços. Após a avaliação da natureza do composto inibidor, concluiu-se que a atividade antimicrobiana derivada do composto inibidor isolado foi, provavelmente, uma bacteriocina. 
Tabela 6 - Atividade antimicrobiana do sobrenadante livre de células e seu concentrado neutralizado de Lactobacillus casei Lc-1, obtido pelo método de perfuração e difusão em ágar. Valores dos halos de inibição em mm.

\begin{tabular}{lcccc}
\hline Leveduras & \multicolumn{2}{c}{ Após 24h } & \multicolumn{2}{c}{ Após 48h } \\
\cline { 2 - 5 } & SLCN & SLCCN & SLCN & SLCCN \\
\hline Cryptococcus albidus & - & $2,4^{\mathrm{Ca}} \pm 0,1$ & - & $2,4^{\mathrm{Ca}} \pm 0,1$ \\
Cryptococcus laurentii & - & - & - & - \\
Candida edax & - & - & - & - \\
Debaryomyces hansenii & - & - & - & - \\
\hline
\end{tabular}

Média e desvio padrão dos halos. A análise foi realizada em duplicata.

${ }^{a, b}$ Letras iguais na mesma linha indicam que não há diferença significativa $(p<0,05)$.

A, B, C Letras iguais na mesma coluna indicam que não há diferença significativa $(p<0,05)$. Comparação com a Tabela 5.

(-) Ausência de halo de inibição; SLCN - sobrenadante livre de células neutralizado; SLCCN sobrenadante livre de células concentrado neutralizado.

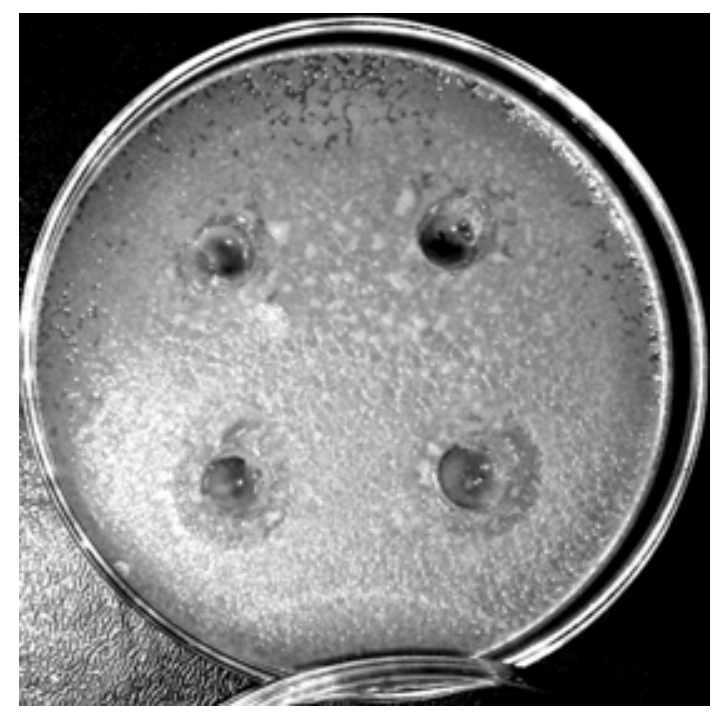

Figura 11 - Fotografia de placa com ágar MPL mostrando o efeito antimicrobiano do sobrenadante livre de células (1) e sobrenadante livre de células concentrado neutralizado (2) de Lc-1 sobre Cryptococcus albidus. Houve formação de halos de inibição.

A metodologia de perfuração e difusão em ágar foi utilizada por Mojgani, Torshizi e Rahimi (2007). Foram isoladas e identificadas três cepas de Lactobacillus 
do intestino de pintainhos, dentre elas, Lactobacillus acidophilus RNL26. O sobrenadante neutralizado apresentou atividade antimicrobiana somente para as bactérias Gram positivas, Listeria monocytogenes e Staphylococcus aureus e não apresentou efeito inibitório sobre bactérias Gram negativas.

\subsubsection{Protocooperação de Debaryomyces hansenii e culturas probióticas}

Para ambas as culturas probióticas La-5 e Lc-1, quando o sobrenadante livre de células e seu concentrado foram adicionados nos poços, foi possível constatar a formação de um intenso halo de desenvolvimento microbiano, de coloração creme, apresentando uma interação positiva com todas as culturas de Debaryomyces hansenii. Esta protocooperação, provavelmente ocorreu pelo fato desta levedura desenvolver-se em produtos lácteos fermentados e na maturação de certos queijos, uma vez que toleram baixo $\mathrm{pH}$, baixa atividade de água, altas concentrações de sal, baixas temperaturas, além de produzir aroma e textura típicos (WELTHAGEN; VILJOEN, 1998; VILJOEN, 2001; FERREIRA; VILJOEN, 2003; BORELLI et al., 2006; BREUER; HARMS, 2006; KESENKAŞ; AKBULUT, 2008). Além disso, as bactérias láticas produzem succinato e ácidos orgânicos, tais como lático e cítrico, os quais podem ser assimilados pelas leveduras como fonte de carbono, fazendo com que estes microrganismos sobrevivam neste ambiente ácido. A liberação de vitaminas e aminoácidos pelas leveduras contribui para o crescimento das bactérias láticas, criando uma protocooperação (BREUR; HARMS, 2006; ÁLVAREZ-MARTIN et al., 2008), também observado no presente estudo (Figura 12).

Estudos mostram também que Debaryomyces hansenii consegue inibir o crescimento de microrganismos patogênicos e deteriorantes, além de contribuir com intensa atividade proteolítica e lipolítica e desenvolvimento de aroma e textura de alguns produtos lácteos fermentados (JAKOBSEN; NARVHUS, 1996; ÁLVAREZMARTIN et al., 2008; LIU; TSAO, 2009a).

Além disso, ao contrário das outras leveduras em estudo, a expressão de diferentes proteases extracelulares produzidas por $D$. hansenii podem proteger esse microrganismo contra os compostos antimicrobianos produzidos pelas culturas láticas, porém os mecanismos de ação ainda são desconhecidos (BREUER; HARMS, 2006). 
Em contrapartida, quando o sobrenadante livre de células e seu concentrado foram neutralizados, nenhuma das culturas de Debaryomyces hansenii apresentou halos de interação positiva com os compostos produzidos pelas culturas láticas. Estes resultados ressaltam a importância dos ácidos orgânicos secretados pelas bactérias láticas como fonte de carbono para as leveduras (WOUTERS et al. 2002; VILJOEN, 2003; ÁLVAREZ-MARTIN et al., 2008).

As leveduras Candida edax, Cryptococcus laurentii e Cryptococcus albidus não apresentaram halos de interação positiva sobre as culturas probióticas, provavelmente pelo fato destas serem microrganismos oportunistas, relacionados a diversos tipos de doenças, as quais afligem principalmente pacientes hospitalizados e imunodeprimidos (JACQUES; CASAREGOLA, 2006). Além disso, não foram identificados estudos relacionados à interação positiva dessas leveduras com bactérias láticas presentes em produtos lácteos fermentados.

Lourens-Hattingh e Viljoen (2001) inocularam no processamento de iogurtes probióticos, Debaryomyces hansenii, Kluyveromyces marxianus, Yarrowia lipolytica e Issatchenkia orientalis. D. hansenii e $Y$. lipolytica foram capazes de controlar o pH do iogurte durante o período de estocagem, prevenindo o excesso de pós-acidificação durante o período de estocagem, além de assegurar a viabilidade das culturas probióticas do iogurte durante a vida de prateleira do produto. 


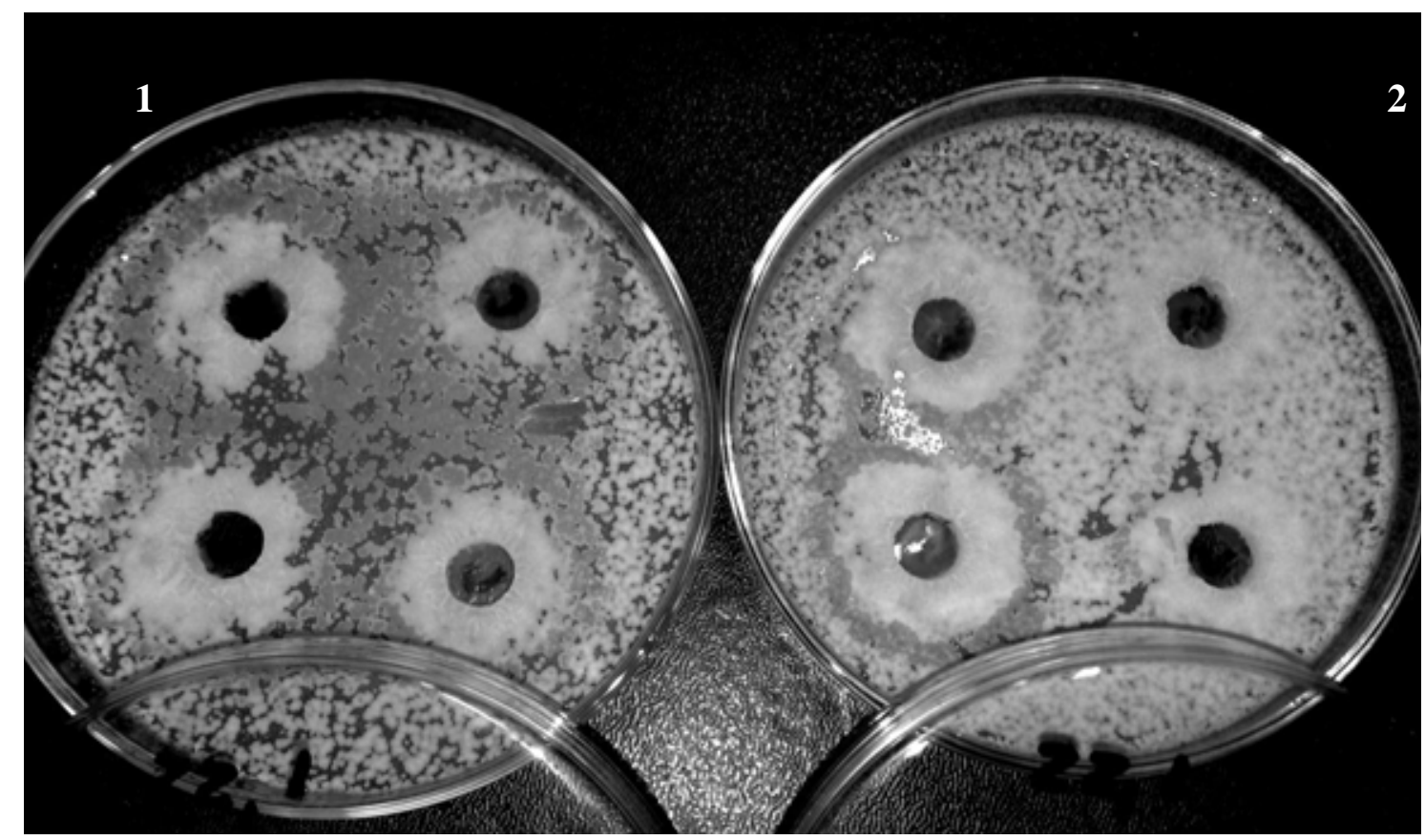

Figura 12 - Fotografia de placa com ágar MPL mostrando os halos com intenso desenvolvimento demonstrando protocooperação de Debaryomyces hansenii com os compostos orgânicos produzidos por La-5 (1) e Lc-1(2). Houve formação de halos de interação positiva.

\subsection{Bebida láctea fermentada pelas culturas probióticas}

\subsubsection{Caracterização físico-química}

\subsubsection{Teores de sólidos totais}

As bebidas lácteas fermentadas por La-5 apresentaram teores de sólidos totais variando de $8,92 \%$ e $9,15 \%$, para a bebida controle e para fermentada com La-5 na presença de Cryptococcus albidus, respectivamente (Tabela 7). A análise de variância do teor de sólidos totais indica que os tratamentos realizados foram estatisticamente diferentes entre si $(p<0,05)$, para a cultura probiótica La-5. 
in

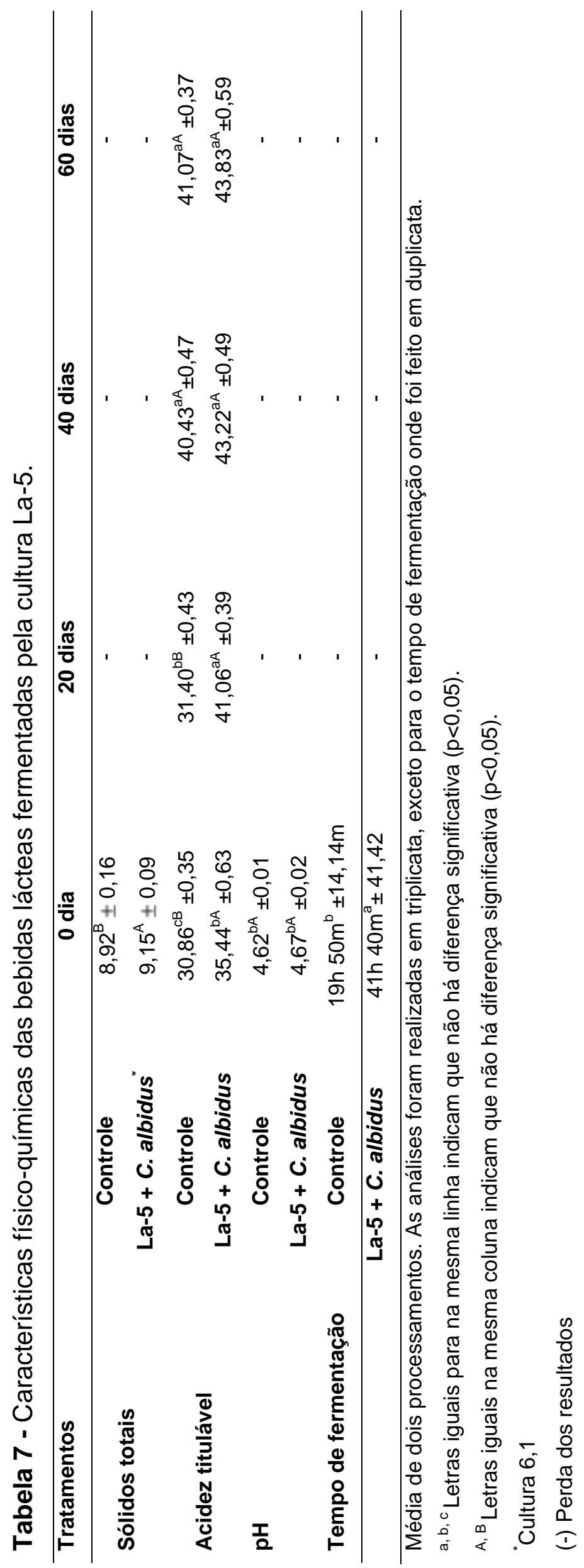


Os teores de sólidos totais nas bebidas lácteas fermentadas por Lc-1 variaram entre 8,92 a 9,15, entre os tratamentos controle, com $C$. albidus e $C$. lauretii (Tabela 8). A análise de variância do teor de sólidos totais indica que os tratamentos controle e com $C$. albidus realizados foram estatisticamente diferentes entre si $(p<0,05)$. Para ambas as culturas probióticas, possivelmente houve diferenças na reconstituição do leite em pó, resultando em bebidas lácteas com teores de sólidos totais diferentes significativamente. No entanto, para as condições normais de preparo das bebidas, esta variação é considerada pequena.

As bebidas preparadas por Sivieri e Oliveira (2002) adicionadas de substituto de gordura apresentaram resultados cujos valores variaram de $8,93 \%$ a $9,16 \%$, muito próximos aos observados no presente estudo.

O teor de sólidos é importante pelas suas propriedades físicas, como a consistência e a viscosidade e pelo valor nutritivo do produto, podendo variar de $9 \%$ a $30 \%$ nos leites fermentados, porém, teores acima de $25 \%$ afetam a disponibilidade da umidade e retardam a atividade da cultura (TAMIME; ROBINSON, 1999). O teor de sólidos totais depende da formulação utilizada, quanto maior a porcentagem de sólidos dos ingredientes usados para o preparo das bebidas lácteas, maior será o teor de sólidos totais (THAMER; PENNA, 2006).

Bebidas lácteas com maiores teores de sólidos totais foram obtidas por diversos autores. Madureira (2004), a qual produziu bebida láctea fermentada, variando as concentrações de soro de queijo, sacarose e oligofrutose, com inóculo de uma cultura láctea mista contendo $S$. thermophilus, L. desbrueckii subsp. bulgaricus, L. acidophilus e Bifidobacterium spp. Os valores de sólidos totais variaram entre $14,37 \%$ e $17,75 \%$. A mesma cultura mista foi utilizada por Gomes (2005) na produção de bebidas lácteas com diferentes concentrações de soro de leite em pó, leite em pó desnatado e isolado protéico de soja. Os valores de sólidos totais variaram entre $13,27 \%$ a 18,46\%. Lima (2003) desenvolveu uma bebida láctea à base de soro de queijo, fortificada com ferro e encontrou valores de sólidos totais que variaram entre $18,12 \%$ a $21,71 \%$. Thamer e Penna (2006) produziram bebidas lácteas funcionais fermentadas por probióticos e acrescidas de prebióticos contendo de 15,68\% a 18,97\% de sólidos totais. 
in

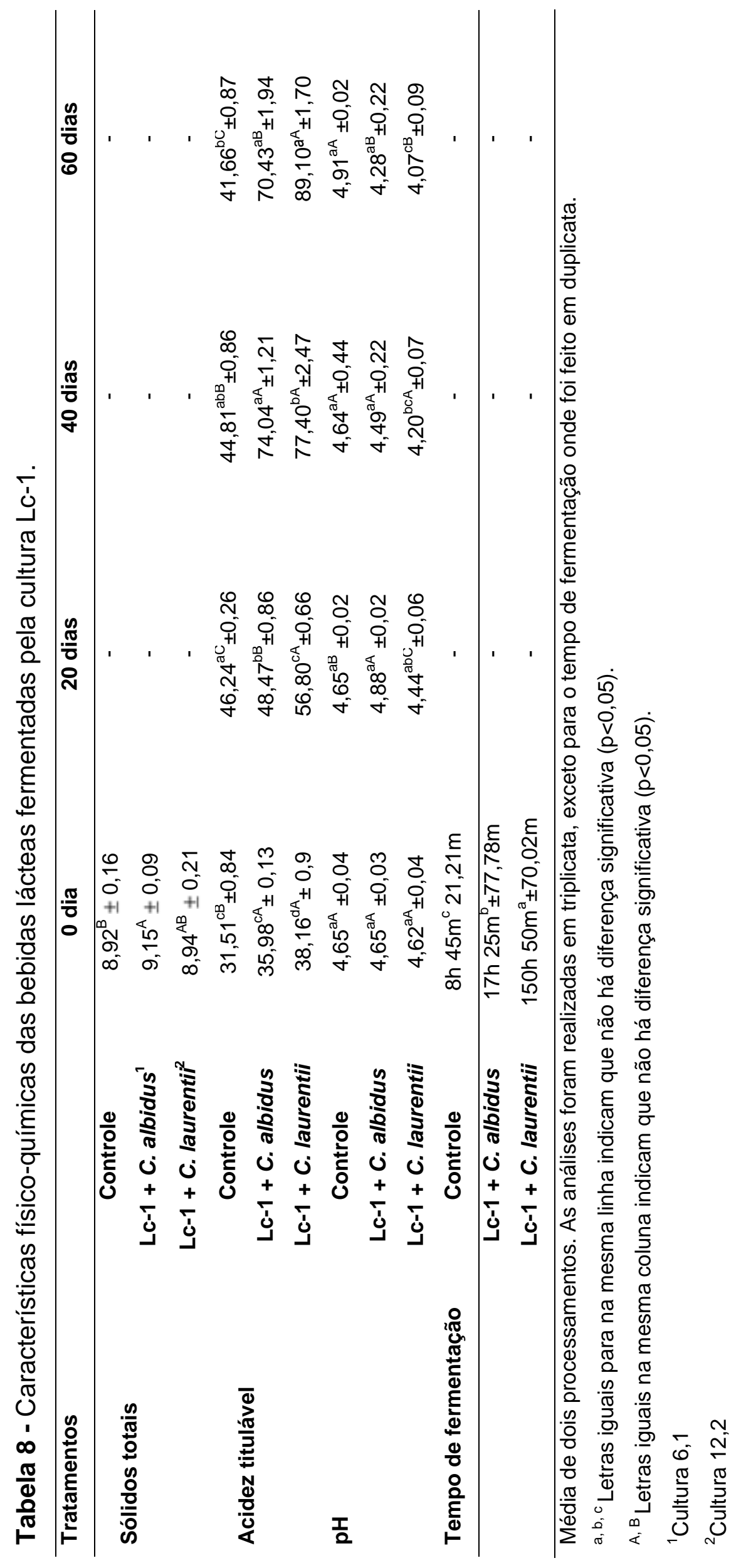




\subsubsection{Acidez}

A pós-acidificação (variação da acidez titulável) das bebidas lácteas fermentadas pela cultura probiótica La-5 (Tabela 7) durante o armazenamento refrigerado (1, 20, 40 e 60 dias), apresentou valores de acidez que variaram de 35,44 a $43,83{ }^{\circ} \mathrm{D}$, e 30,86 a $41,07^{\circ} \mathrm{D}$ para o tratamento com Cryptococcus albidus e controle, respectivamente. No tratamento no controle houve diferença significativa $(p<0,05)$ entre o período de 40 e 60 dias com os demais, e no tratamento com $C$. albidus, houve diferença entre o período de 0 dias com os demais. Para cultura probiótica Lc-1 (Tabela 8), durante o armazenamento refrigerado (1, 20, 40 e 60 dias), os valores de acidez variaram de 31,51 a $41,66^{\circ} \mathrm{D}$, de 35,98 a $70,43^{\circ} \mathrm{D}$ e de 38,16 a $89,10^{\circ} \mathrm{D}$ para o tratamento controle, com Cryptococcus albidus, e Cryptococcus laurentii, respectivamente. Para todos os períodos de estocagem, houve diferenças significativas $(p<0,05)$ entre o tratamento controle e os adicionados de levedura. Diferenças significativas também foram encontradas para cada tratamento entre os diferentes períodos analisados $(p<0,05)$.

Quando comparado os tratamentos, a pós-acidificação de La-5 e Lc-1 foi maior no tratamento com a presença de levedura do que no controle, além de aumentar os valores de acidez para ambos os tratamentos durante a estocagem refrigerada. Apesar da cultura probiótica La-5 utilizada neste estudo possuir baixa capacidade de acidificação (ZACARCHENCO; MASSAGUERROIG, 2004), durante a estocagem, a pós-acidificação foi observada nas bebidas lácteas fermentadas. A pós-acidificação das bebidas fermentadas por Lc-1 foi superior àquela observada nas bebidas fermentadas por La-5.

Durante o período de estocagem refrigerada a acidez seguirá aumentando lentamente, pois as culturas probióticas continuam viáveis durante o período de vida de prateleira (ADAMS; MOSS, 1997). Essas mudanças na acidez do produto são dependentes da temperatura de refrigeração, do tempo de armazenamento e do poder de pós-acidificação das culturas utilizadas. 


\subsubsection{Valor de $\mathrm{pH}$}

O valor de $\mathrm{pH}$ encontrado nas bebidas lácteas fermentadas com a cultura probiótica La-5 variou de 4,62 a 4,67 para o tratamento controle e adicionado de C. albidus, conforme Tabela 7. A análise de variância do $\mathrm{pH}$ de La-5 indica que não houve diferença significativa entre os tratamentos realizados $(p<0,05)$.

Para a cultura probiótica Lc-1, os valores de pH variaram de 4,07 a 4,91. Não houve diferença significativa $(p<0,05)$ entre os períodos de estocagem para o tratamento controle e adicionado de C. albidus.

O controle do $\mathrm{pH}$ é importante no processo de fermentação, pois a separação do soro está diretamente relacionada com este parâmetro (GOMES, 2005). Além disso, o baixo $\mathrm{pH}$ dificulta o desenvolvimento de microrganismos indesejáveis (VILJOEN, 2001). Nas bebidas lácteas funcionais desenvolvidas por Madureira (2004), Gomes (2005) e Thamer e Penna (2006), os valores de $\mathrm{pH}$ variaram de 4,60 a 4,89, 4,41 a 4,65 e 4,72 a 4,83, respectivamente. Brandão (2006) elaborou uma bebida láctea fermentada por L. acidophilus usando diferentes concentrações de inulina. Foram encontrados valores iniciais de $\mathrm{pH}$ que variaram de 4,10 a 4,76. Após os períodos de estocagem $(7,14,21$ e 28 dias), os valores de $\mathrm{pH}$ variaram de 4,50 a 3,62, aumentando assim, a acidez durante a vida de prateleira do produto.

As diferenças nos valores de $\mathrm{pH}$ nos produtos lácteos podem estar relacionadas ao tipo e porcentagem de cultura utilizada, à atividade desta cultura, ao valor estabelecido para finalizar a fermentação, à quantidade de soro de leite utilizada na elaboração das bebidas lácteas, à adição de diferentes ingredientes, assim como ao tempo e a temperatura de armazenamento (THAMER; PENNA, 2006).

\subsubsection{Tempo de fermentação}

O tempo de fermentação foi definido como o tempo necessário para que a bebida láctea fermentada atingisse aproximadamente o valor $\mathrm{pH}$ de 4,6, para então, dar início ao resfriamento até $20^{\circ} \mathrm{C}$. O tempo de fermentação da cultura 
lática La-5 na bebida láctea fermentada foi maior na presença da levedura Cryptococcus albidus $(41 \mathrm{~h} 40 \mathrm{~m})$ do que no tratamento controle $(19 \mathrm{~h} 50 \mathrm{~m})$, sendo estatisticamente diferentes entre si $(p<0,05)$, conforme a Tabela 7 e Figura 13.

Para a cultura probiótica Lc-1, o tempo de fermentação foi maior na presença de $C$. laurentii $(150 \mathrm{~h} 50 \mathrm{~m})$ do que na presença de $C$. albidus (17h $25 \mathrm{~m})$ e no controle ( $8 \mathrm{~h} 45 \mathrm{~m})$, sendo estaticamente diferentes entre si $(p<0,05)$, conforme a Tabela 8 e Figura 14.

Os tempos de fermentação observados são muito superiores àqueles encontrados em processos industriais e também citados na literatura. Com intuito de estudar o efeito antimicrobiano das culturas probióticas separadamente, não foi utilizado no presente estudo as culturas tradicionais do iogurte, como Streptococcus thermophilus e Lactobacillus delbrueckii subsp. bulgaricus, as quais reduzem muito o tempo de fermentação do produto, por serem mais proteolíticas do que as culturas probióticas, possuírem maior poder de acidificação e maior atividade de $\beta$-galactosidase (SHAH, 2001; MADUREIRA, 2004). As culturas probióticas não produzem altas concentrações de ácidos lático, cítrico e a galactose, sendo assim, o consumo desses ácidos pelas leveduras faz com que o tempo de fermentação aumente (VILJOEN, 2003).

O uso de culturas tradicionais do iogurte reduziu o tempo de fermentação em estudos realizados por Madureira (2004), Gomes (2005) e Thamer e Penna (2006), os quais produziram bebidas lácteas fermentadas com inóculos de uma cultura láctea mista contendo $S$. thermophilus, L. delbrueckii subsp. bulgaricus, L. acidophilus e Bifidobacterium spp. e encontraram uma variação de 270 a 350 minutos, 180 a 375 minutos, 180 a 255 minutos, respectivamente. Castro (2007) encontrou tempos reduzidos de fermentação variando de 4,50 a 5,20 horas em bebidas lacteas probióticas inoculadas com culturas mistas (La-5, Streptococcus thermophilus e Bifidobacterium animalis $\mathrm{Bb}-12)$. 


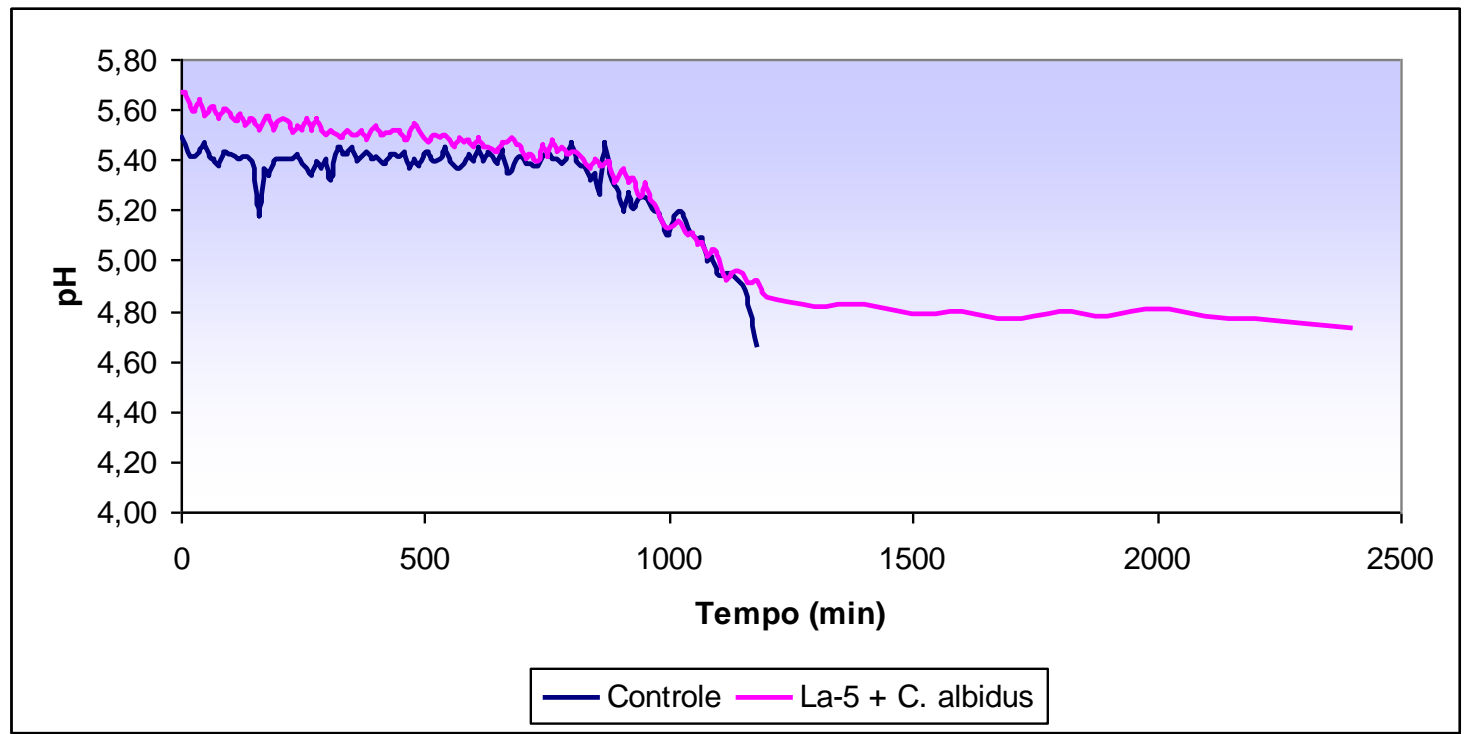

Figura 13 - Curvas de acidificação das bebidas lácteas fermentadas pela cultura La-5.

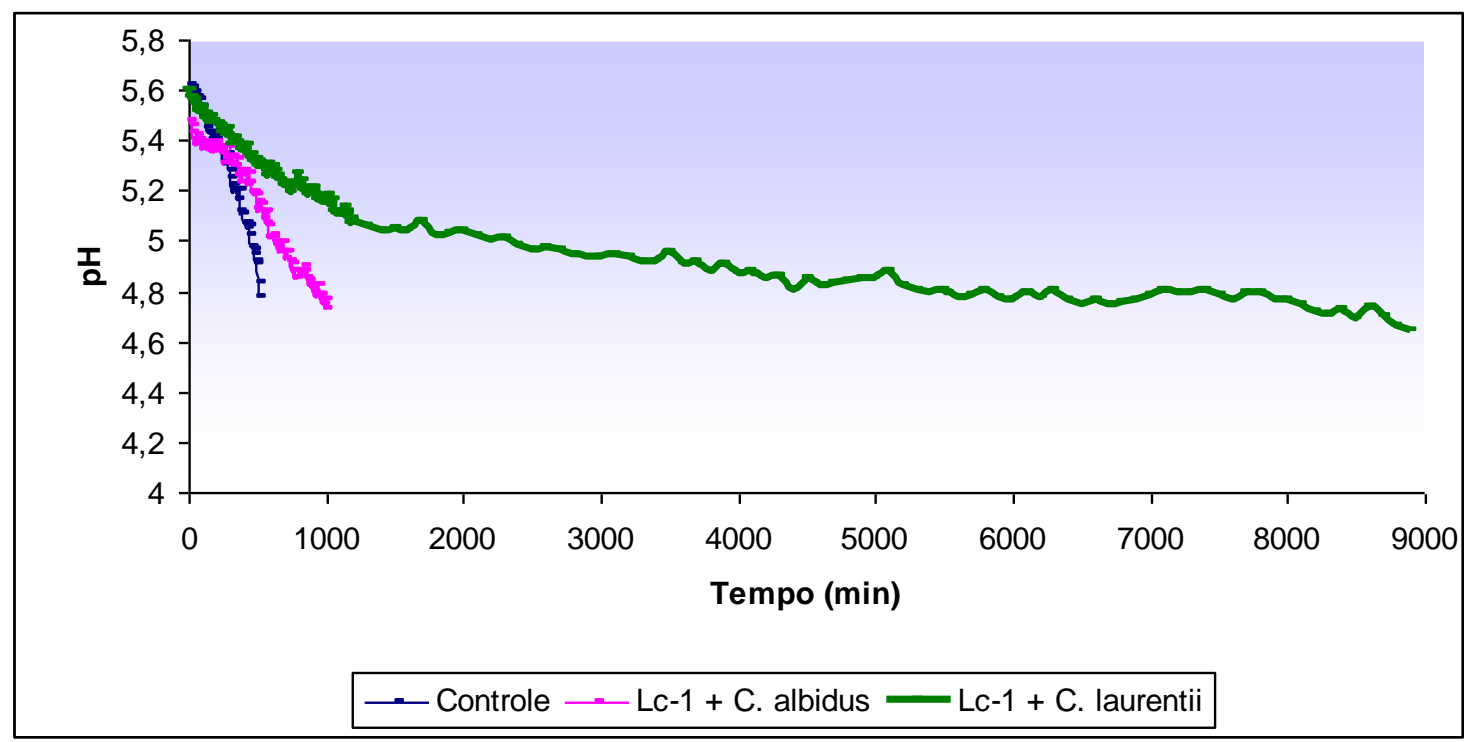

Figura 14 - Curvas de acidificação das bebidas lácteas fermentadas pela cultura Lc-1. 


\subsubsection{Viabilidade das bactérias láticas}

A densidade populacional de $L$. acidophilus presente nas bebidas lácteas fermentadas variaram de 11,73 a 9,17 log UFC. $\mathrm{mL}^{-1}$ (Tabela 9), podendo ser visualizado diferenças significativas entre os tratamentos $(p<0,05)$ apenas no período de estocagem (60 dias). As populações de $L$. casei apresentaram densidade populacional maior que $L$. acidophilus variando de 14,32 a 10,02 log UFC. $\mathrm{mL}^{-1}$ (Tabela 10), demonstrando diferenças significativas entre os tratamentos após 20 dias de estocagem. Ao contrário do controle, os tratamentos com $C$. albidus e $C$. laurentii apresentaram diferenças significativas nos períodos de estocagem. Durante a vida de prateleira de produtos lácteos fermentados como a bebida láctea, as bactérias láticas tendem a diminuir sua viabilidade.

As culturas probióticas na presença das leveduras aumentaram sua densidade populacional. Isso não foi observado no tratamento controle, no qual houve a redução da densidade populacional de 2 ciclos logarítmicos durante 0 período de estocagem. Segundo Liu e Tsao (2009b), uma hipótese para o aumento da viabilidade das bactérias láticas seria que as leveduras na sua forma não viável agem como fontes de nutrientes para o desenvolvimento dessas bactérias, liberando extrato de leveduras, vitaminas e aminoácidos. É importante ressaltar que a interação da bactéria lática com as leveduras é dependente de diferentes mecanismos e diferentes combinações de espécies. Além disso, as leveduras que não fermentam a lactose e galactose são consideradas mais efetivas quando presentes em iogurtes, pois não produzem $\mathrm{CO}_{2}$ e etanol, os quais geram odores desagraveis nestes produtos.

Todos os tratamentos atenderam aos requisitos de densidade populacional de bactérias láticas do Regulamento Técnico de Identidade e Qualidade de Bebida Láctea e para alegação do efeito funcional (BRASIL, 2005; BRASIL, 2008). 


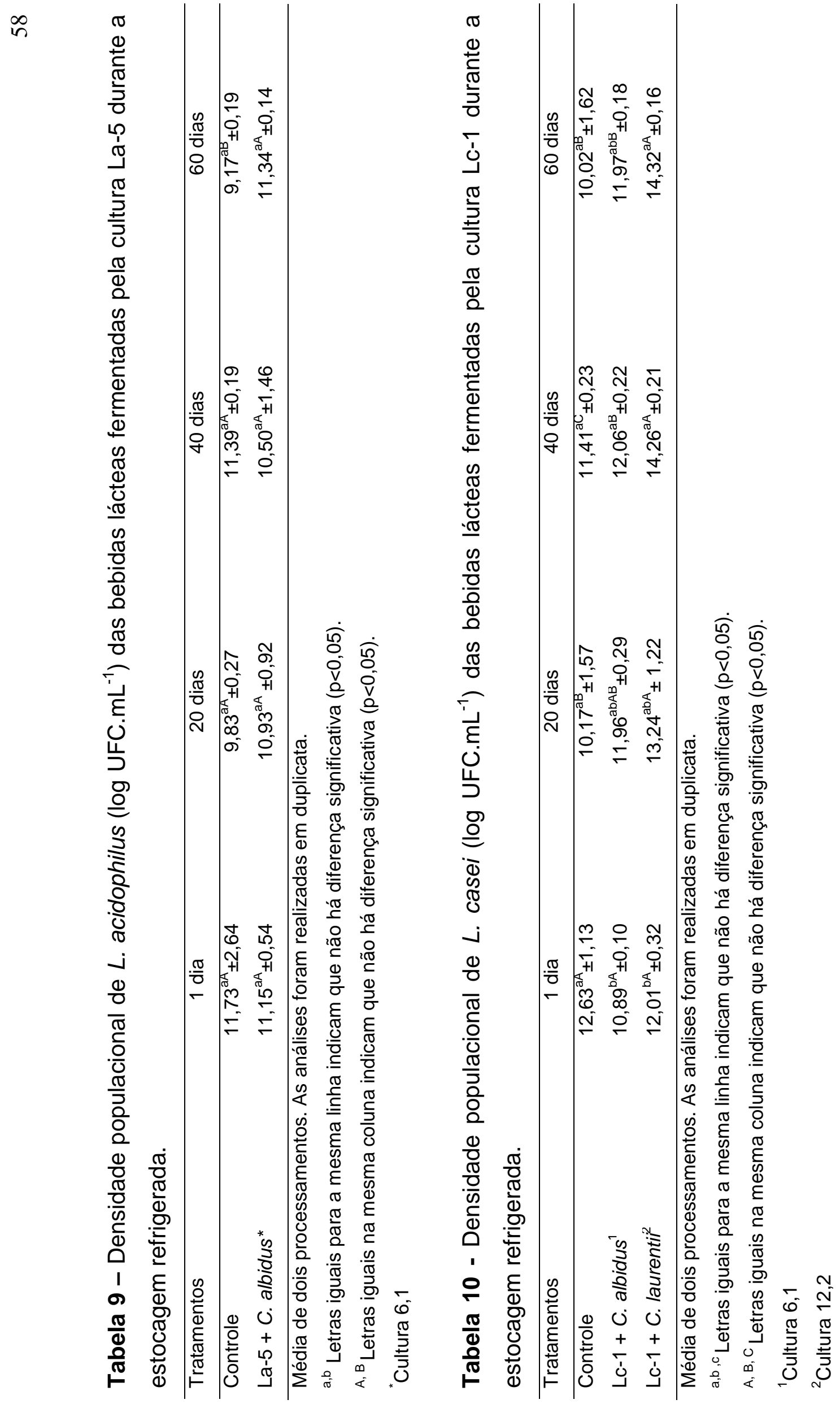


Viljoen (2001) relata que a perda da viabilidade de bactérias láticas tende a ocorrer na presença de leveduras. No presente estudo, a adição da levedura na bebida láctea fermentada não influenciou na viabilidade celular de L. acidophilus e L. casei. A viabilidade e a atividade das bactérias probióticas durante a preparação e armazenamento é de grande importância industrial. No entanto, o baixo $\mathrm{pH}$ após a fermentação, os ácidos produzidos no trato gastrointestinal, o teor de oxigênio nos produtos, a temperatura, a baixa atividade proteolítica, o desenvolvimento lento, a disponibilidade de nutrientes, o oxigênio dissolvido no leite e a adição de substâncias durante a etapa de produção, são fatores que afetam também a viabilidade das bactérias probióticas (CASTRO, 2007).

São poucos os estudos relacionados à viabilidade de $L$. acidophilus e $L$. casei quando aplicados isoladamente em bebidas lácteas fermentadas. Madureira (2004) encontrou densidade populacional de Lactobacillus acidophilus em bebidas lácteas fermentadas funcionais, variando de 7,60 a 11,06 log UFC. $\mathrm{mL}^{-1}$ atendendo ao requisito de $10^{6}$ UFC. $\mathrm{mL}^{-1}$ de bactérias viáveis no produto, durante sua vida de prateleira. Em um estudo semelhante realizado por Gomes (2005) e Thamer e Penna (2006), foram encontradas densidades populacionais de 6,8 a 12,6 log UFC. $\mathrm{mL}^{-1}$ e 8,06 a 12,41 log UFC. $\mathrm{mL}^{-1}$ nas contagens de Lactobacillus acidophilus, respectivamente. Em um estudo realizado por Brandão (2006) em bebidas lácteas adicionadas de prebióticos com inóculo de L. acidophilus (1\% e $2 \%$ ), foi encontrado inicialmente densidade populacional de 10,16 a 10,70 log UFC. $\mathrm{mL}^{-1}$. Após 28 dias, L. acidophilus decresceu 7,33 a 8,49 $\log$ UFC. $\mathrm{mL}^{-1}$, porém permaneceu superior ao pré-requisito mínimo preconizado pela legislação, de 8 log UFC. $\mathrm{mL}^{-1}$. Castro (2007) avaliou a influência de diferentes proporções de soro de queijo e oligofrutose em bebidas lácteas probióticas inoculadas com culturas mistas contendo La-5, Streptococcus thermophilus e Bifidobacterium animalis (Bb-12). A densidade populacional de $L$. acidophilus variou de 6,09 a 6,84 log UFC. $\mathrm{mL}^{-1}$ no produto. No estudo semelhante realizado por Cunha e colaboradores (2008), as maiores densidades populacionais encontradas em bebidas lácteas probióticas foram de $6 \log$ UFC. $\mathrm{mL}^{-1}$. 


\subsubsection{Viabilidade de fungos filamentosos e leveduriformes}

Todos os tratamentos apresentaram densidade populacional de fungos filamentosos e leveduriformes < 10 UFC. $\mathrm{mL}^{-1}$, mesmo àqueles que continham o inóculo das culturas de leveduras Cryptococcus albidus e Cryptococcus laurentii. Provavelmente, as bactérias láticas liberaram compostos orgânicos antifúngicos, os quais inibiram o desenvolvimento das leveduras. Esses metabólitos podem ser ácidos, tais como acético, lático ou outros compostos, como as bacteriocinas (DE MUYNCK et al., 2004). Ausência de leveduras foi relatada por Madureira (2004) e Brandão (2006) na produção de bebidas lácteas funcionais. Tebaldi e colaboradores (2006) analisaram 20 amostras de diferentes marcas comerciais de bebidas lácteas, não sendo encontradas densidades populacionais para fungos filamentosos e leveduriformes.

Em contrapartida, Reis (2008) encontrou em bebidas lácteas comerciais densidades populacionais de fungos filamentosos e leveduriformes $<1$ a 3,7 $x$ $10^{9}$ UFC. $\mathrm{mL}^{-1}$.

\subsubsection{Atividade antimicrobiana da bebida láctea fermentada por bactérias láticas probióticas sobre leveduras}

Durante a fermentação da bebida láctea, o desenvolvimento da cultura lática La-5 e Lc-1, provavelmente inibiu o desenvolvimento da levedura Cryptococcus albidus e Lc-1 também inibiu Cryptococcus laurentii, resultando em densidades populacionais inferiores a 10 UFC. $\mathrm{mL}^{-1}$. No processo de fermentação três fenômenos ocorrem no leite: (1) transformação da lactose em ácido lático, conferindo o sabor ácido, abaixando o pH e levando a coagulação do leite; (2) produção de diversos compostos voláteis; (3) formação de outros compostos, tais como exopolissacarídeos, que aumentam a viscosidade, além do ácido fólico e bacteriocinas (TAMIME; ROBINSON, 1999).

A elevada atividade antimicrobiana dos lactobacilos está relacionada com a produção de ácido orgânicos e bacteriocinas, resultando no decréscimo do $\mathrm{pH}$, aumentando a vida de prateleira do produto.

Os iogurtes e as bebidas lácteas fornecem um ambiente seletivo para o crescimento de leveduras devido ao baixo $\mathrm{pH}$. As leveduras não estão 
envolvidas no processo de fermentação, principalmente pelas altas temperaturas durante o processamento. No entanto, a presença de fungos filamentosos e leveduriformes não são aceitáveis em produtos lácteos fermentados, sendo os equipamentos, a má sanitização, a adição de polpas de fruta ou outros ingredientes, como principais fontes de contaminação, além de alterar as características do produto final, como sensoriais, físico-químicas e microbiológicas (VILJOEN, 2001).

Contagens de fungos filamentosos e leveduriformes maiores ou iguais a $10^{4}$ UFC.ml ${ }^{-1}$ são frequentemente encontradas em iogurtes e bebidas, principalmente pela adição de polpas de frutas (VILJOEN, 2001). Adicionalmente, a adição de açúcar age como um substrato para fermentação e amplia o risco de leveduras deteriorantes. Embora, a densidade populacional de leveduras se mantenha relativamente estável em baixas temperaturas, o desenvolvimento destes microrganismos pode aumentar quando o produto é exposto a altas temperaturas, levando ao encurtamento da vida de prateleira do produto.

No presente estudo, a presença de leveduras nos produtos lácteos, não alterou a densidade populacional das bactérias láticas. Nos testes da capacidade antimicrobiana in vitro, observamos que a natureza do composto inibidor para La-5 não era de natureza ácida e que na bebida láctea elaborada, a acidificação foi reduzida. Quando a cultura Lc-1 foi utilizada, observou-se que a natureza do composto inibidor era provavelmente um ácido orgânico, e a bebida láctea produzida apresentou elevada acidez. Em ambos os produtos, mesmo com a adição dos fungos, estes não estavam viáveis no produto após a fermentação e durante o período de estocagem. No entanto, o mecanismo de inibição é diferente para as culturas La-5 e Lc-1 


\section{CONCLUSÕES}

As culturas probióticas apresentaram atividades antimicrobianas sobre algumas leveduras isoladas de bebidas lácteas fermentadas. As células probióticas não apresentaram efeito inibidor sobre leveduras, no entanto, o sobrenadante livre de células, sobrenadante concentrado, sobrenadante livre de células neutralizado e sobrenadante concentrado neutralizado das culturas La-5 e Lc-1 apresentaram atividade antimicrobiana in vitro sobre Cryptococcus albidus. A cultura Lc-1 também apresentou efeito inibidor para Cryptococcus laurentii. A substância produzida por La-5, provavelmente não é um ácido, pois após a neutralização, o efeito antimicrobiano manteve-se presente. $O$ efeito antimicrobiano produzido pela cultura Lc-1 foi reduzido quando efetuada a neutralização, tratando-se provavelmente de um composto ácido.

No desenvolvimento das bebidas lácteas fermentadas por culturas probióticas La-5 houve inibição de Cryptococcus albidus e nos produtos com Lc-1, houve inibição de ambas as culturas de leveduras adicionadas, durante todo o período de estocagem refrigerada. A presença da levedura alterou os valores de acidez titulável, $\mathrm{pH}$ e tempo de fermentação, sem afetar a viabilidade das bactérias láticas.

O efeito antimicrobiano das bactérias láticas probióticas La-5 e Lc-1, observado in vitro e in situ, apresentam mecanismos diferentes.

As culturas probióticas comerciais La- 5 e Lc- 1 podem ser utilizadas como bioconservantes de produtos lácteos, oferecendo produtos seguros com ampla vida de prateleira. 


\section{REFERÊNCIAS BIBLIOGRÁFICAS ${ }^{1}$}

ADAM, M. R.; MOSS, M. O. Microbiologia de los alimentos. Zaragoza: Acríbia, 1997. $464 \mathrm{p}$.

AGÊNCIA NACIONAL DE VIGILÂNCIA SANITÁRIA. Portaria DETEN/MS n 29 de 22 de janeiro de 1996. Aprova a extensão de uso de NISINA com a função de conservador para queijos pasteurizados. Diretor: Marcelo Azalim. Disponível em: <http://www.anvisa.gov.br/legis/portarias/29_96.htm\#>. Acesso em: 30 ago. 2009.

AKTYPIS, A.; KALANTZOPOULOS, G. Study on bacteriocins produced by lactic cultures. Medical Microbiology Letters, London, v. 5, n. 1, p. 35, 1996. Suplemento.

ALONSO, B.; ISAY, S. Bactérias do grupo Lactobacillus casei: caracterização, viabilidade como probióticos em alimentos e sua importância para a saúde humana. Archivos Latino americanos de Nutrición, Caracas, v. 57, n. 4, p. 373-380, 2007.

ÁLVAREZ-MARTíN, P. et al. Interaction between dairy yeasts and lactic acid bacteria strains during milk fermentation. Food Control, New York, v. 19, n. 1, p. $62-70,2008$.

ASSOCIAÇÃO BRASILEIRA DE INDÚSTRIAS DA ALIMENTAÇÃO. Compêndio da legislação e alimentos: consolidação das mesmas e padrões de alimentos. São Paulo, 2003. p. 376-382. v. 1/A: Atos do Ministério da Saúde. Revisão 9.

ATANASSOVA, M. et al. Isolation and partial biochemical characterization of a proteinaceous anti-bacteria and anti-yeast compound produced by Lactobacillus paracasei subsp. paracasei strain M3. International Journal of Food Microbiology, Amsterdam, v. 87, n. 12, p. 63-73, 2003.

BALDUÍNO, R.; OLIVEIRA, A. S.; HAULY, M. C. O. Cultura lática mista com potencial de aplicação como cultura inibidora em produtos cárneos. Ciência e Tecnologia de Alimentos, Campinas, v. 19, n. 3, p. 356-362, 1999.

BARNETT, J. A. A. History of research on yeasts 2: Louis Pasteur and his contemporaries, 1850-1880. Yeast, Chichester, v. 16, n. 8, p. 755-771, 2000.

BORELLI, B. M. et al. Yeast populations associated with the artisanal cheese produced in the region of Serra da Canastra. World Journal of Microbiology and Biotechnology, Oxford, v. 22, n. 11, p. 1115-1119, 2006.

BRANDÃO, W. A. P. L. N. T. M. Elaboração de bebida láctea fermentada simbiótica de soro lácteo. 70 f. 2006. Dissertação (Mestrado)-Programa de Pós-Graduação em Ciência dos Alimentos, Universidade Federal de Santa Catarina, Florianópolis, 2006.

\footnotetext{
${ }^{1}$ Segundo normas para referências bibliográficas, ABNT 6023.
} 
BRASIL. Ministério da Agricultura, Pecuária e Abastecimento. Instrução normativa $n^{\circ} 51$, de 18 de setembro de 2002. Aprova os regulamentos técnicos de produção, identidade e qualidade do leite tipo $A$, do leite tipo $B$, do leite tipo $C$, do leite pasteurizado e do leite cru refrigerado e o regulamento técnico da coleta de leite cru refrigerado e seu transporte a granel. Diário Oficial Diário Oficial [da República Federativa do Brasil], Brasília, DF, 20 set. 2002.

BRASIL. Ministério da Agricultura, Pecuária e Abastecimento. Instrução Normativa no 16, de 23 de agosto de 2005. Aprova o regulamento técnico de identidade e qualidade de bebida láctea. Diário Oficial Diário Oficial [da República Federativa do Brasil], Brasília, DF, 24 ago. 2005.

BRASIL. Ministério da Agricultura, Pecuária e Abastecimento. Portaria ํo 146, de 07 de março de 1996. Aprova os regulamentos técnicos de identidade e qualidade dos produtos lácteos. Diário Oficial Diário Oficial [da República Federativa do Brasil], Brasília, DF, 11 mar. 1996.

BRASIL. Ministério da Saúde. Agência Nacional de Vigilância Sanitária. Alimentos com alegações de propriedades funcionais e ou de saúde, novos alimentos/ingredientes, substâncias bioativas e probióticos. Atualizado em julho, 2008. Diário Oficial [da República Federativa do Brasil], Brasília, DF, jul. 2008.

BRASIL. Ministério da Saúde. Agência Nacional de Vigilância Sanitária. Resolução RDC $n^{\circ} 2$, de 07 de janeiro de 2002. Aprova o regulamento técnico de substâncias bioativas e probióticos isolados com alegação de propriedades funcional e ou de saúde. Diário Oficial [da República Federativa do Brasil], Brasília, DF, 09 jan. 2002.

BREUER, U.; HARMS, H. Debaryomyces hansenii - an extremophilic yeast with biotechnological potential. Yeast, Chichester, v. 23, n. 6, p. 415-437, 2006.

BROMBERG, R. et al. Características da bacteriocina produzida por Lactococcus lactis ssp. hordniae CTC 484 e seu efeito sobre Listeria monocytogenes em carne bovina. Ciência e Tecnologia de Alimentos, Campinas, v. 26, n. 1, p. 135-144, 2006.

BRUL, S.; COOTE, P. Preservative agents in foods: mode of action and microbial resistance mechanisms. International Journal of Food Microbiology, Amsterdam, v. 50, n. 12, p. 1-17, 1999.

BUCK; B. L.; AZCARATE-PERIL, M. A.; KLAENHAMMER, T. R. Role of autoinducer-2 on the adhesion ability of Lactobacillus acidophilus. Journal of Applied Microbiology, Oxford, v. 107, n. 1, p. 269-279, 2009.

CARNICEL, F. A. Qualidade microbiológica de ricota e estudos de resistência de leveduras do gênero Debaryomyces isoladas deste produto lácteo. 2004. 71 f. Dissertação (Mestrado)-Programa de Pós-Graduação em Engenharia e Ciência de Alimentos, Instituto de Biociências, Letras e Ciências Exatas, Universidade Estadual Paulista, São José do Rio Preto, 2004. 
CASE, R. A.; BRADLEY, J. R. R. L.; WILLIAMS, R. R. Chemical and physical methods. In: AMERICAN PUBLIC HEALTH ASSOCIATION. Standard methods for the examination of dairy products. 15. ed. Washington, 1985. p. 327-404.

CASTRO, F. P. Influência de diferentes proporções de soro de queijo e oligofrutose sobre as propriedades de bebidas lácteas fermentadas simbióticas.126 f. 2007. Dissertação (Mestrado)-Programa de Pós-Graduação em Ciência dos Alimentos, Universidade Federal de Santa Catarina, Florianópolis, 2007.

CLEVELAND, J. et al. Bacteriocins: safe, natural antimicrobials for food preservation. International Journal of Food Microbiology, Amsterdam, v. 71, n. 1, p. 1-20, 2001.

COGAN, T. M; ACCOLAS, J. P. Dairy starter cultures. Davis: Wiley-Vch, 1996. 277 p.

COSTA, G. M. P. et al. Mastite por leveduras em bovinos leiteiros do Sul do Estado de Minas Gerais, Brasil. Ciência Rural, Santa Maria, v. 38, n. 7, p. 1938-1942, 2008.

CUNHA, T. M. et al. Avaliação físico-química, microbiológica e reológica de bebida láctea e leite fermentado adicionados de probióticos. Semina: Ciências Agrárias, Londrina, v. 29, n. 1, p. 103-116, 2008.

DE MUYNCK, C. et al. Potential of selected lactic acid bacteria to produce food compatible anti-fungal metabolites. Microbiological Research, Jena, v. 159, n. 4, p. 339-346, 2004.

DE VUYST, L.; LEROY, F. Bacteriocins from lactic acid bacteria: production, purification, and food applications. Journal of Molecular Microbiology and Biotechnology, Hethersett, v. 13, n. 4, p. 194-199, 2007.

DUREK, C. M. Verificação das boas práticas de fabricação em indústrias de leite e derivados, registradas no serviço de inspeção federal - SIF. 2005. 97 p. Dissertação (Mestrado)-Programa de Pós-Graduação em Ciências Veterinárias, Setor de Ciências Agrárias, Universidade Federal do Paraná, Curitiba, 2005.

ELGADI, Z. A. M.; GADIR, W. S. A.; DIRAR, H. A. Isolation and identification of lactic acid bacteria yeast from dairy milk Khartoum State (Sudan). Research Journal of Microbiology, Hamilton, v. 3, n. 3, p. 163-168, 2008.

FOOD AND AGRICULTURE ORGANIZATION OF THE UNITED NATIONS; WORLD HEALTH ORGANIZATION. Guidelines for the evaluation of probiotics in food. Report of a joint $\mathrm{FAO} / \mathrm{WHO}$ working group on drafting guidelines for the evaluation for the probiotics in food. London, 2002.

FERREIRA, A. D.; VILJOEN, B. C. Yeasts as adjunct starters in matured Cheddar cheese. International Journal of Food Microbiology, Amsterdam, v. 86, n. 12, p. 131-140, 2003. 
FRANCO, B. D. G. M.; LANDGRAF M.; DESTRO, M. T. Microbiologia dos alimentos. São Paulo: Atheneu, 1996. 182 p.

GOMES, R. G. Efeitos dos teores de leite, soro e proteínas de soja nas características físico-quimicas, microbiológicas, reológicas e sensoriais de bebidas lácteas probióticas. 2005. 159 f. Dissertação (Mestrado)Programa de Pós-Graduação em Engenharia e Ciência de Alimentos, Instituto de Biociências, Letras e Ciências Exatas, Universidade Estadual Paulista, São José do Rio Preto, 2005.

GUPTA, V.; GARG, R. Probiotics. Indian Journal of Medical Microbiology, Pondicherry, v. 27, n. 3, p. 202-209, 2009.

GUSMÃO, V. V. Qualidade microbiológica e ocorrência de leveduras em leites pasteurizados leites tipo A, B, C. 2005. 78 f. Dissertação (Mestrado)Programa de Pós-Graduação em Engenharia e Ciência de Alimentos, Instituto de Biociências, Letras e Ciências Exatas, Universidade Estadual Paulista, São José do Rio Preto, 2005.

HOFFMANN, F. L.; PENNA, A. L. B.; VINTURIM, T. M. Avaliação da qualidade de diferentes marcas comerciais de bebidas lácteas. Revista do Instituto de Laticínios Candido Tostes, Juiz de Fora, v. 53, n. 304, p. 95-101, 1998.

HUI, Y. H. Dairy science and technology handbook. Eureka: Wiley-Vch, 1993. v. 3, 487 p.

HUTT, P. et al. Antagonistic activity of probiotic lactobacilli and bifidobacteria against entero and uropathogens. Journal of Applied Microbiology, Oxford, v. 100, n. 6, p. 1324-1332, 2006.

INSTITUTO ADOLFO LUTZ. Normas analíticas do Instituto Adolfo Lutz: métodos químicos e físicos para análise de alimentos. 3. ed. São Paulo: Instituto Adolfo Lutz, 2008.

INTERNATIONAL DAIRY FEDERERATION. Detection and enumeration of Lactobacillus acidophilus. Bulletin of the IDF, Brussels, n. 306, p. 23-33, 1995.

Yogurt enumeration of characteristic microorganisms. International IDF Standard, Brussels, n. 41, p. 1-4, 1997.

JACQUES, N.; CASAREGOLA, S. Safety assessment of dairy microorganisms: The hemiascomycetous yeasts. International Journal of Food Microbiology, Amsterdam, v. 126, n. 3, p. 321-326, 2008.

JAKOBSEN, M.; NARVHUS, J. Yeasts and their possible beneficial and negative effects on the quality of dairy products. International Dairy Journal, Barking, v. 6, n. 89, p. 755-768, 1996.

JAMUNA, M.; JEEVARATNAM, K. Isolation and characterization of lactobacilli from some traditional fermented foods and evaluation of bacteriocins. Journal of General and Applied Microbiology, Bunkyoku, v. 50, n. 2, p. 79-90, 2004. 
KAVAS, G. et al. Characterization of yeasts isolated from artisinal Turkish dairy products. International Journal of Dairy Sciences, Cambridge, v. 1, n. 1, p. 44-50, 2006.

KESENKAŞ, H.; AKBULUT, N. Yeasts as ripening adjunct cultures in Turkish white brined cheese production. Turkish Journal of Veterinary and Animal Sciences, Ankara, v. 32, n. 5, p. 327-333, 2008.

KHAWCHAROENPORN, T.; APISARNTHANARAK, A; MUNDY, L. M. Nonneoformans cryptococcal infections: a systematic review. Infection, Munchen, v. 35, n. 2, p. 50-58, 2007.

KIM, Y. et al. Lactobacillus acidophilus reduces expression of enterohemorhagic Escherichia coli $\mathrm{O} 157: \mathrm{H} 7$ virulence factors by inhibiting autoinducer-2-like activity. Food Control, Guildford, v.19, n. 11, p.1042-1050, 2008.

KOS, B. et al. Characterization of the three selected probiotic strains for the application in food industry. World Journal of Microbiology and Biotechnology, Oxford, v. 24, n. 5, p. 699-707, 2008.

KURTZMAN, C. P.; FELL, J. W. The yeasts: a taxonomy study. 4. ed. Amsterdam: Elsevier Science, 1998. 1005 p.

LAUBSCHER, P. J.; VILJOEN, B. C. The resistance of dairy yeasts against commercially available cleaning compounds and sanitizers. Food Technology and Biotechnology, Zagreb, v. 37, n. 2, p. 281-286, 1999.

LIMA, C. D. L. C. et al. Bactérias do acido lácticas e leveduras associadas com o queijo-de-minas artesanal produzido na região da Serra do Salitre, Minas Gerais. Arquivo Brasileiro de Medicina Veterinária e Zootecnia, Belo Horizonte, v. 61, n. 1, p. 266-272, 2009.

LIMA, M. C. G.; MADUREIRA, F. C. P.; PENNA, A. L. B. Bebidas lácteas nutritivas e refrescantes, Milkbizz, São Paulo, n. 3, p. 411, 2002.

LIMA, S. M. C. G. Desenvolvimento de uma bebida láctea à base de soro de queijo, fortificada com ferro. 2003.154 f. Dissertação (Mestrado)Programa de Pós-Graduação em Engenharia e Ciência de Alimentos, Instituto de Biociências, Letras e Ciências Exatas, Universidade Estadual Paulista, São José do Rio Preto, 2003.

LIU, S-Q.; TSAO, M. Biocontrol of dairy moulds by antagonistic dairy yeast Debaryomyces hansenii in yoghurt and cheese at elevated temperatures. Food Control, Guildford, v. 20, n. 9, p. 852-855, 2009a.

; et al. Enhancement of survival of probiotic and non-probiotic latic acid bacteria by yeasts in fermented milk under non-refrigerated conditions. International Journal of Food Microbiology, Amsterdam, v. 135, n. 1, p. 3438, 2009b. 
LJUNGH, A.; TORKEL, W. Lactic acid bacteria as probiotics. Current Issues in Intestinal Microbiology, Hethersett, v. 8, n. 1, p. 73-90, 2006.

LOURENS-HATTINGH, A.; VILJOEN, B. C. Growth and survival of a probiotic yeast in dairy products. Food Research International, Barking, v. 34, n. 9, p. 791-796, 2001.

MADIGAN, M. T.; MARTINKO, J. M.; PARKER, J. Microbiologia de Brock. São Paulo: Pearson Prentice Hall, 2008. 608 p.

MADUREIRA, F. C. P. Desenvolvimento de uma bebida láctea funcional. 2004. 173 f. Dissertação (Mestrado)-Programa de Pós-Graduação em Engenharia e Ciência de Alimentos, Instituto de Biociências, Letras e Ciências Exatas, Universidade Estadual Paulista, São José do Rio Preto, 2004.

MANSOR, A. P. Qualidade microbiológica e ocorrência de leveduras em diferentes tipos de manteiga. 2001. $67 \mathrm{f}$. Dissertação (Mestrado)-Programa de Pós-Graduação em Engenharia e Ciência de Alimentos, Instituto de Biociências, Letras e Ciências Exatas, Universidade Estadual Paulista, São José do Rio Preto, 2001.

MARCHIORI, E. Alto valor agregado. Indústria de Laticínios, São Paulo, n. 65 , p. 10-13, 2006.

MISHRA, V.; PRASAD, D. N. Application of in vitro methods for selection of Lactobacillus casei strains as potential probiotics. International Journal of Food Microbiology, Amsterdam, v. 103, n. 1, p. 109-115, 2005.

MOJGANI, N.; TORSHIZI, M. A. K.; RAHIMI, S. Screening of locally isolated lactic acid bacteria for use as a probiotics in poultry in Iran. The Journal of Poultry Science, Ikenodai, v. 44, n. 4, p. 357-365, 2007.

MORENO, I. et al. Características gerais de bacteriocinas de bactérias láticas. Indústria de Laticínios, São Paulo, v. 5, p. 57-60, 2000a.

; et al. Efeito da nisina produzida por Lactococcus lactis subsp. lactis ATCC11454 em diferentes linhas de lactococos. Revista do Instituto de Laticínios Candido Tostes, Juiz de Fora, v. 55, n. 315, p. 35-40, 2000 b.

; et al. Nisina no controle de bactérias esporogênicas em produtos lácteos. Boletim da Sociedade Brasileira de Ciência e Tecnologia dos Alimentos, Campinas, v. 33, n. 2, p. 215-228, 1999.

; LERAYER, A. L. S.; LEITÃO, M. F. F. Bacteriocinas de bactérias láticas: utilização em laticínios e fatores que afetam a sua eficiência. Disponível

em: <http://www.infobibos.com/Artigos/2008_3/bacteriocinas/index.htm>. Acesso em: 27 ago. 2009.

Boletim Técnico Informativo do Centro de Tecnologia de Laticínio, Campinas, v. 2, n. 10, p. 5, 1999. 
MUFANDAEDZA, J. et al. Antimicrobial properties of lactic acid bacteria and yeast-LAB cultures isolated from traditional fermented milk against pathogenic Escherichia coli and Salmonella enteritidis strains. International Journal of Food Microbiology, Amsterdam, v. 108, n. 1, p. 147-152, 2006.

NARDI, R. M. D. et al. Purification and molecular characterization of antibacterial compounds produced by Lactobacillus murinus strain L1. Journal of Applied Microbiology, Oxford, v. 99, n. 3, p. 649-656, 2005.

NES, I. F.; JOHNSBORG, O. Exploration of antimicrobial potential in LAB by genomics. Current Opinion in Biotechnology, Londres, v. 15, n. 2, p. 100104, 2004.

OLIVEIRA, M. N.; DAMIN, M. R. Efeito do teor de sólidos e da concentração de sacarose na acidificação, firmeza e viabilidade de bactérias do iogurte e probióticas em leite fermentado. Ciência e Tecnologia de Alimentos, Campinas, n. 23, p. 172-176, 2003. Suplemento.

OSTLIE, H. M.; HELLAND, M. H.; NARVHUS, J. A. Growth and metabolism of selected strains of probiotic bacteria in milk. International Journal of Food Microbiology, Amsterdam, v. 87, n. 12, p. 17-27, 2003.

OSUNTOKI, A. A; EJIDE, O. R.; OMONIGBEHIN, E. A. Antagonistic effects on enteropathogens and plasmid analysis of lactobacilli isolated from fermented dairy products. Biotechnology, Frankfurt, v. 7, n. 2, p. 311-316, 2008.

PAN, X. et al. The acid, bile tolerance and antimicrobial property of Lactobacillus acidophilus NIT. Food Control, New York, v. 20, n. 6, p. 598-602, 2009.

PARVEZ, S. et al. Probiotics and their fermented food products are beneficial for health. Journal of Applied Microbiology, Oxford, v. 100, n. 6, p. 11711185, 2006.

PEDROSO, R. S.; FERREIRA, J. C.; CANDIDO, R. C. The isolation and characterization of virulence factors of Cryptococcus spp. from saprophytic sources in the city of Ribeirão Preto, São Paulo, Brazil. Microbiological Research, Jena, v. 164, n. 3, p. 221-227, 2007.

PEREIRA, V. G.; GÓMEZ, R. J. H. C. Atividade antimicrobiana de Lactobacillus acidophilus contra microrganismos patogênicos veiculados por alimentos. Semina: Ciências Agrárias, Londrina, v. 28, n. 2, p. 229-240, 2007.

PIMENTEL, C. V. M. B.; FRANCKI, V. M.; GOLLUCKE, A. P. B. Alimentos funcionais: introdução as principais substâncias bioativas em alimentos. São Paulo: Varela, 2005. 95 p.

PRACHYAKIJ, P. et al. Selection and identification of lactic acid bacteria that inhibit yeast contaminants isolated from fermented plant beverages, Songklanakarin Journal of Science and Technology, Hat Yai, v. 29, n. 2, p. 211-218, 2007. Suplemento. 
PRADO, C. S. et al. Atividade antimicrobiana de bactérias láticas de embutidos curados sobre a Listeria monocytogenes. Arquivos Brasileiros de Medicina Veterinária e Zootecnia, Belo Horizonte, v. 52, n. 4, p. 417-423, 2000.

RAVULA, R. R.; SHAH, N. P. Selective enumeration of Lactobacillus casei from yogurt and fermented milk drinks. Biotechnology Techniques, Kew, v. 12, n. 11, p. 819-822, 1998.

REIS, J. A. Qualidade microbiológica e ocorrência de leveduras em bebidas lácteas fermentadas, adição de polpas de frutas, comercializadas na região de São José do Rio Preto-SP. 2008. 95 f. Dissertação (Mestrado)Programa de Pós-Graduação em Engenharia e Ciência de Alimentos, Instituto de Biociências, Letras e Ciências Exatas, Universidade Estadual Paulista, São José do Rio Preto, 2008.

ROBINSON, R. K. Dairy microbiology handbook. New York: WileyInterscience, 2002. $765 \mathrm{p}$.

RODGERS, S. Novel applications of live bacteria in food-services: probiotics and protective cultures. Trends in Food Science \& Technology, Guildford, v. 19, n. 4, p. 188-197, 2008.

RODRIGUES, M. A. M.; SANTOS, K. A. Qualidade microbiológica de iogurtes e bebidas lácteas fermentadas, comercializadas em Uberlândia/MG. Higiene Alimentar, São Paulo, v. 21, n. 150, p. 39-40, 2007.

ROSS, R. R.; MORGAN, S.; HILL, C. Preservation and fermentation: past, present and future. International Journal of Food Microbiology, Amsterdam, v. 79 , n. 23, p. 3-16, 2002.

SAARELA, M. et al. Probiotic bacteria: safety, functional and technological properties. Journal of Biotechnology, Amsterdam, v. 84, n. 3, p. 197-215, 2000.

SCHILLINGER, U.; LUCKE, F. K. Antibacterial activity of Lactobacillus sake isolated from meat. Applied and Environmental Microbiology, Washington, v. 55, n. 8, p. 1901-1906, 1989.

SCHULZ, D. et al. Bacteriocinas: mecanismo de ação e uso na conservação de alimentos. Alimentos e Nutrição, Araraquara, v. 14, n. 2, p. 229-235, 2003.

SEIBEL, N. F.; CANSIAN, R. L. Análise de diferentes concentrações de soro na produção de bebida láctea. Revista Leite e Derivados, São Paulo, n. 52, p. 44-49, 2000.

SHAH, N. P. Functional cultures and health benefits. International Dairy Journal, Barking, v. 17, n. 11, p. 1262-1277, 2007.

Functional foods from probiotics and prebiotics. Food Technology, Chicago, v. 55, n. 11, p. 46-52, 2001. 
SILVA, F. A. S.; AZEVEDO, C. A. V. Versão do programa computacional Assistat para o sistema operacional Windows. Disponível em: <http://www.assistat.com.br>. Acesso em: 27 set. 2009.

SILVA, J. V. Qualidade microbiológica de ricota e ocorrência de leveduras em diferentes amostras de queijo Minas Frescal. 2003. 69 f. Dissertação (Mestrado)-Programa de Pós-Graduação em Engenharia e Ciência de Alimentos, Instituto de Biociências, Letras e Ciências Exatas, Universidade Estadual Paulista, São José do Rio Preto, 2003.

SIVIERI, K.; OLIVEIRA, M. N. Avaliação da vida-de-prateleira de bebidas lácteas preparadas com "fat replacers" (Litesse e Dairylo). Ciência e Tecnologia de Alimentos, Campinas, v. 22, n. 1, p. 24-31, 2002.

SUZUKI, M. et al. A phylogenetic study on galactose-containing Candida species based on 18S ribosomal DNA sequences. Journal of Genetic and Applied Microbiology, Tokyo, v. 45, n. 5, p. 229- 238, 1999.

TAMIME A. Y.; ROBINSON, R. K. Yogurt: science and technology. 2. ed. Oxford: Pergamon Press, 1999. 619p.

TEBALDI, V. M. R. et al. Avaliação microbiológica de bebidas lácteas fermentadas adquiridas no comércio varejista do sul de Minas Gerais. Ciência e Agrotecnologia, Lavras, v. 31, n. 4, p. 1085-1088, 2006.

THAMER, K. G.; PENNA, A. L. B. Caracterização de bebidas lácteas funcionais fermentadas por probióticos e acrescidas de prebiótico. Ciência e Tecnologia de Alimentos, Campinas, v. 26, n. 3, p. 589-595, 2006.

THOMSEN, M. N. D. Probiotics-Enhancing health with beneficial bacteria. Alternative \& Complementary Therapies, New York, v. 12, n .1, p. 14-21, 2006.

VASILJEVIC, T.; SHAH, N. P. Probiotics from Metchnikoff to bioactives. International Dairy Journal, Barking, v. 18, n. 7, p. 714-728, 2008.

VILJOEN, B. C. et al. Development of yeast populations during processing and ripening of blue veined cheese. Food Technology and Biotechnology, Zagreb, v. 41, n. 4 p. 291-297, 2003.

The interaction between yeasts and bacteria in dairy environments. International Journal of Food Microbiology, Amsterdam, v. 69, n. 12, p. 3744, 2001.

VOULGARI, K. et al. Antifungal activity of nonstarter lactic acid bacteria isolates from dairy products. Food Control, New York, v. 21, n. 2, p. 136-142, 2010.

WALSTRA, P. et al. Dairy technology: principles of milk properties and processes. New York: Marcel Dekker, 1999. 727 p.

WOUTERS, J. T. M.; GEURTS, T. J. Dairy science and technology. 2. ed. New York: CRC Press, 2006. 782 p. 
WELTHAGEN, J. J.; VILJOEN, B. C. Yeast profile in Gouda cheese during processing and ripening. International Journal of Food Microbiology, Amsterdam, v. 41, n. 3, p. 185-194, 1998.

WOUTERS, J. T. M. et al. Microbes from raw milk for fermented dairy products. International Dairy Journal, Barking, v. 12, n. 23, p. 91-109, 2002.

YANG, V. W.; CLAUSEN, C. A. Determining the suitability of lactobacilli antifungal metabolites for inhibiting mould growth. World Journal of Microbiology and Biotechnology, Oxford, v. 21, n. 67, p. 977-981, 2005.

ZACARCHENCO, P. B.; MASSAGUERROIG, S. Avaliação sensorial, microbiológica e de pós-acidificação durante a vida-de-prateleira de leites fermentados contendo Streptococcus thermophilus, Bifidobacterium longum e Lactobacillus acidophilus. Ciência e Tecnologia de Alimentos, Campinas, v. 24, n. 4, p. 674-679, 2004. 